Prepared in cooperation with the Commonwealth of Puerto Rico

\title{
Hydrogeology of Puerto Rico and the Outlying Islands of Vieques, Culebra, and Mona
}
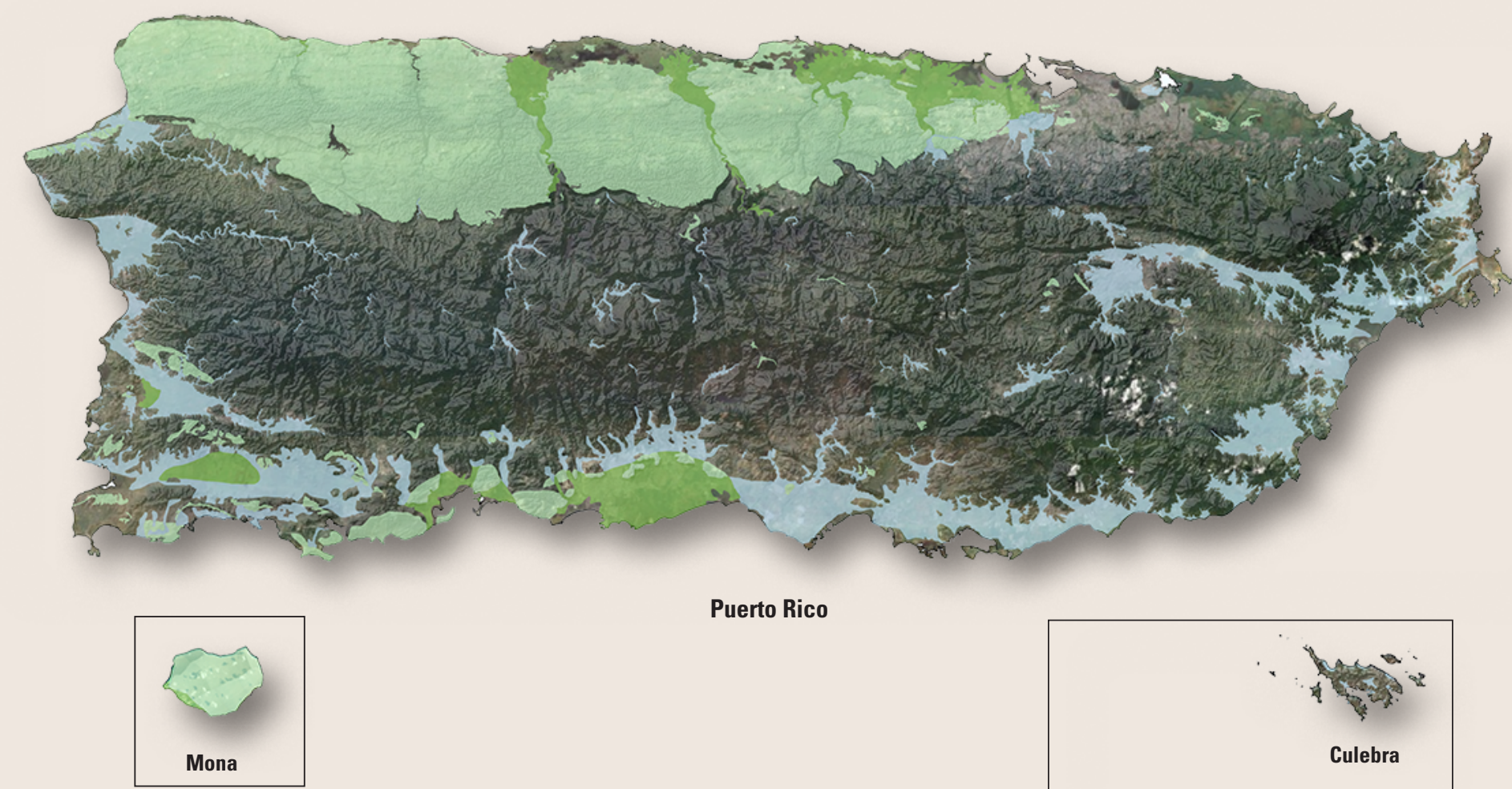

Puerto Rico

Scientific Investigations Map 3296

U.S. Department of the Interior

U.S. Geological Survey 



\section{Hydrogeology of Puerto Rico and the Outlying Islands of Vieques, Culebra, and Mona}

By Fernando Gómez-Gómez, Jesús Rodríguez-Martínez, and Marilyn Santiago

Prepared in cooperation with the Commonwealth of Puerto Rico

Scientific Investigations Map 3296 


\title{
U.S. Department of the Interior SALLY JEWELL, Secretary
}

\section{U.S. Geological Survey Suzette M. Kimball, Acting Director}

\author{
U.S. Geological Survey, Reston, Virginia: 2014
}

For more information on the USGS - the Federal source for science about the Earth, its natural and living resources, natural hazards, and the environment—visit http://www.usgs.gov or call 1-888-ASK-USGS.

For an overview of USGS information products, including maps, imagery, and publications, visit http://Www.usgs.gov/pubprod

To order this and other USGS information products, visit http://store.usgs.gov

Any use of trade, firm, or product names is for descriptive purposes only and does not imply endorsement by the U.S. Government.

Although this information product, for the most part, is in the public domain, it also may contain copyrighted materials as noted in the text. Permission to reproduce copyrighted items must be secured from the copyright owner.

Suggested citation:

Gómez-Gómez, Fernando, Rodríguez-Martínez, Jesús, and Santiago, Marilyn, 2014, Hydrogeology of Puerto Rico and the outlying islands of Vieques, Culebra, and Mona: U.S. Geological Survey Scientific Investigations Map 3296, 40 p. plus 2 pls., http://dx.doi.org/10.3133/sim3296.

ISSN 2329-132X (online) 


\section{Contents}

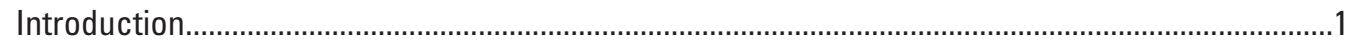

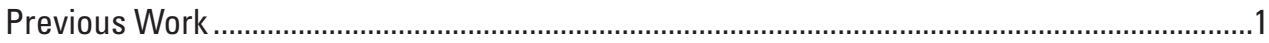

Methodology Used to Prepare the Hydrogeologic Maps ...........................................................2

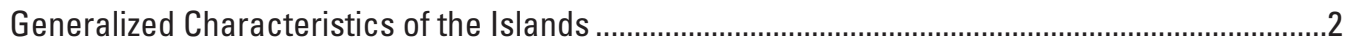

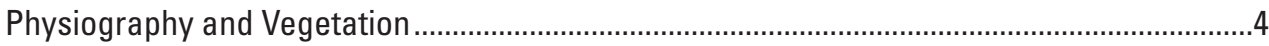

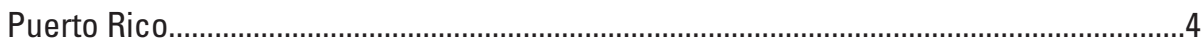

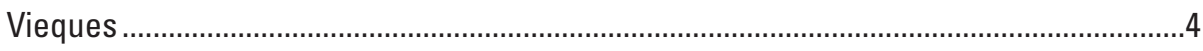

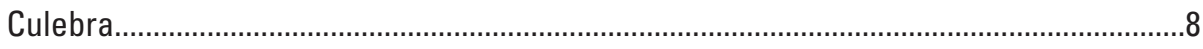

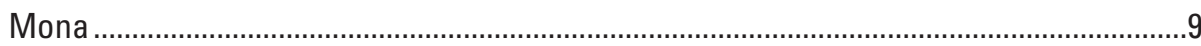

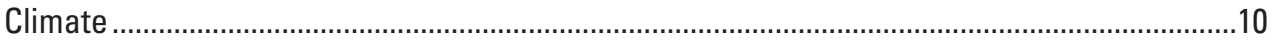

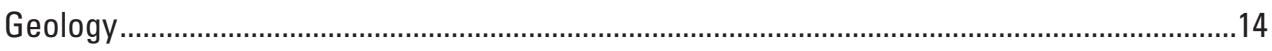

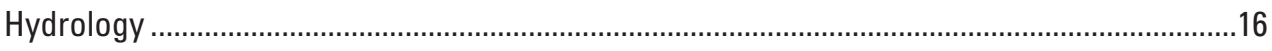

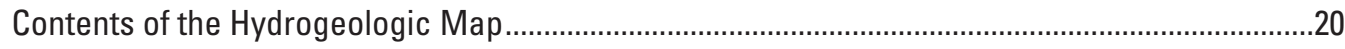

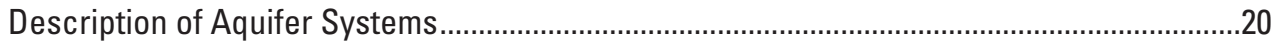

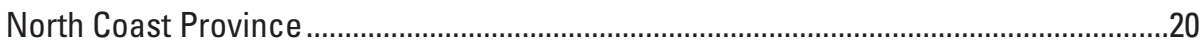

West Coast to Río Grande de Arecibo Area .............................................................20

Río Grande de Arecibo to Río de la Plata Area..........................................................25

Río de la Plata to Río Espíritu Santo Area.....................................................................26

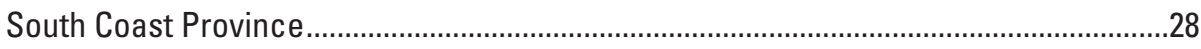

Patillas to Ponce Area ..................................................................................................28

Tallaboa-Guayanilla-Yauco-Guánica Valleys ..............................................................30

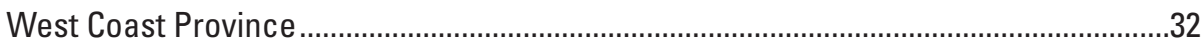

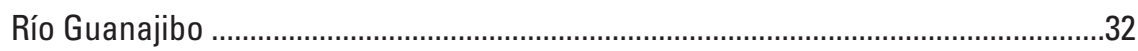

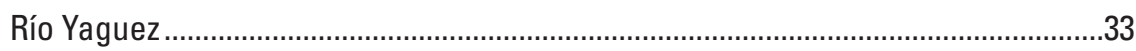

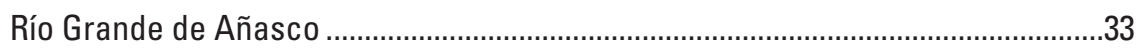

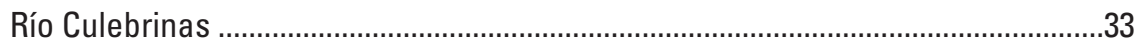

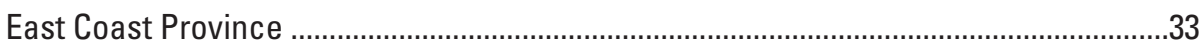

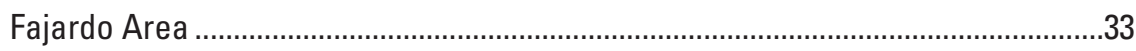

Naguabo-Humacao Area ..............................................................................................3

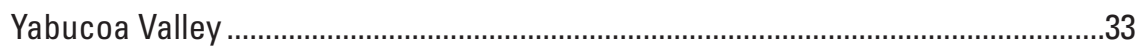

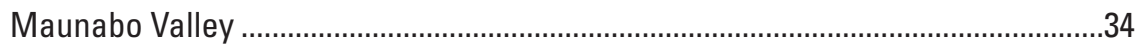

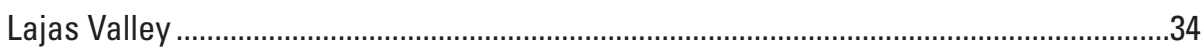

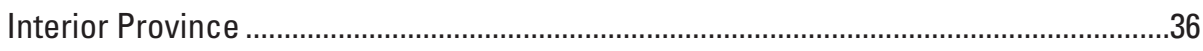

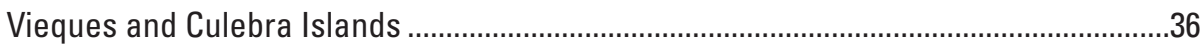

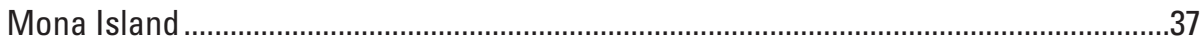

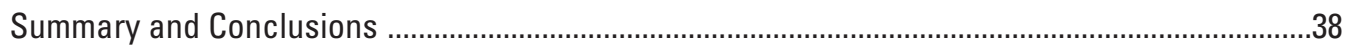

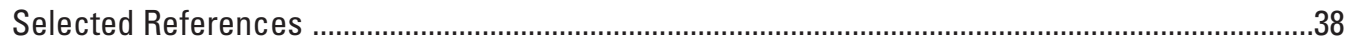




\section{Figures}

1. Map showing location of Puerto Rico, Vieques, Culebra, and Mona Islands ...................3

2. Map showing geographic regions of Puerto Rico and outlying islands.............................5

3. Map showing generalized topographic relief of Puerto Rico …......................................

4. Map showing generalized topographic relief and geographic features of Vieques island.

5. Map showing generalized topographic relief and geographic features of Culebra island

6. Map showing generalized topographic relief and geographic features of Mona island.

7. Map showing climatic subdivisions of Puerto Rico and outlying islands

8. Map showing distribution of mean annual precipitation in Puerto Rico ...........................12

9. Graph showing 10-year moving average rainfall trends at San Juan and Aguirre, Puerto Rico

10. Map showing generalized geology of Puerto Rico and the outlying islands. .15

11. Map showing principal perennial streams and surface-water gaging stations in Puerto Rico.

12. Map showing 10-digit hydrologic units for Puerto Rico ...............................................18

13. Diagram showing generalized water balance for the island of Puerto Rico ...................19

14. Map showing groundwater provinces and aquifers of Puerto Rico and outlying islands

15. Map showing generalized surficial geology of the North Coast Limestone aquifer system and the location of deep exploratory test wells.

16. Stratigraphic chart showing varied nomenclature used for the same rocks in the North Coast Province.

17. Generalized hydrogeologic cross section through the North Coast Limestone aquifer system between the Río Grande de Arecibo and the Río Grande de Manatí near Barceloneta.

18. Graph showing initial heads in test wells penetrating the Lares Limestone in the lower aquifer.

19. Graph showing head change at selected industrial and public-supply wells in the North Coast Limestone lower aquifer in the area of Barceloneta

20. Generalized hydrogeologic cross section through the North Coast Limestone aquifer system in the San Juan area.

21. Map showing areal extent of the South Coastal Alluvial Plain aquifer system and major irrigation infrastructure

22. Generalized hydrogeologic cross section through the South Coastal Alluvial Plain aquifer system near Ponce

23. Generalized hydrogeologic cross section through the Río Tallaboa alluvial valley aquifer west of Ponce...

24. Generalized hydrogeologic cross section through the lower Río Guanajibo alluvial valley aquifer near Cabo Rojo

25. Map showing Lajas Valley and major geographic features near the southwestern coast of Puerto Rico

26. Map showing location of generalized surficial geology of Mona Island .37 


\section{Tables}

1. Geographic regions of Puerto Rico ……...................................................................

2. Basic streamflow statistics for selected gaging stations in Puerto Rico .........................16

\section{Plates}

1. Hydrogeologic map of the island of Puerto Rico

2. Hydrogeologic maps of the islands of Vieques, Culebra, and Mona, Puerto Rico

\section{Acknowledgments}

The authors are indebted to numerous U.S. Geological Survey staff for their contributions in the publication of the report: former staff members Rafael Dacosta and Vicente Quiñones-Aponte, who compiled data from available reports and files for use in the preparation of the preliminary hydrogeologic base map, and Thalia Veve for her cartographic work. Also José Alicea and Francisco Maldonado for their contribution to the illustrations; Wanda Molina for reviewing the groundwater withdrawal estimates; and Sigfredo Torres-González, Robert Renken, and José Rodríguez for their dedication in advancing the state of knowledge of the islands' hydrogeology as part of the Caribbean Islands Regional Aquifer System Analysis Program. 


\section{Conversion Factors and Datums}

SI to Inch/Pound

\begin{tabular}{|c|c|c|}
\hline Multiply & By & To obtain \\
\hline \multicolumn{3}{|c|}{ Length } \\
\hline millimeter $(\mathrm{mm})$ & 0.03937 & inch (in.) \\
\hline meter $(\mathrm{m})$ & 3.281 & foot $(\mathrm{ft})$ \\
\hline kilometer (km) & 0.6214 & mile (mi) \\
\hline \multicolumn{3}{|c|}{ Area } \\
\hline hectare (ha) & 2.471 & acre \\
\hline square kilometer $\left(\mathrm{km}^{2}\right)$ & 247.1 & acre \\
\hline \multicolumn{3}{|c|}{ Flow rate } \\
\hline cubic meter per second $\left(\mathrm{m}^{3} / \mathrm{s}\right)$ & 35.31 & cubic foot per second $\left(\mathrm{ft}^{3} / \mathrm{s}\right)$ \\
\hline liter per second $(\mathrm{L} / \mathrm{s})$ & 15.85 & gallon per minute (gal/min) \\
\hline cubic meter per day $\left(\mathrm{m}^{3} / \mathrm{d}\right)$ & 264.2 & gallon per day (gal/d) \\
\hline millimeter per year $(\mathrm{mm} / \mathrm{yr})$ & 0.03937 & inch per year (in/yr) \\
\hline \multicolumn{3}{|c|}{ Transmissivity* } \\
\hline meter squared per day $\left(\mathrm{m}^{2} / \mathrm{d}\right)$ & 10.76 & foot squared per day $\left(\mathrm{ft}^{2} / \mathrm{d}\right)$ \\
\hline \multicolumn{3}{|c|}{ Specific capacity } \\
\hline liter per second per meter $(\mathrm{L} / \mathrm{s} / \mathrm{m})$ & 0.01077 & $\begin{array}{l}\text { cubic feet per second per foot } \\
\quad\left(\mathrm{ft}^{3} / \mathrm{s} / \mathrm{ft}\right)\end{array}$ \\
\hline
\end{tabular}

Temperature in degrees Celsius $\left({ }^{\circ} \mathrm{C}\right)$ may be converted to degrees Fahrenheit $\left({ }^{\circ} \mathrm{F}\right)$ as follows:

$$
{ }^{\circ} \mathrm{F}=\left(1.8 \times{ }^{\circ} \mathrm{C}\right)+32
$$

Temperature in degrees Fahrenheit $\left({ }^{\circ} \mathrm{F}\right)$ may be converted to degrees Celsius $\left({ }^{\circ} \mathrm{C}\right)$ as follows:

$$
{ }^{\circ} \mathrm{C}=\left({ }^{\circ} \mathrm{F}-32\right) / 1.8
$$

Vertical coordinate information is referenced to local mean sea level.

Horizontal coordinate information is referenced to the Puerto Rico Datum, 1940 adjustment.

Altitude, as used in this report, refers to distance above mean sea level.

*Transmissivity: The standard unit for transmissivity is cubic meter per day per square meter per meter of aquifer width $\left[\left(\mathrm{m}^{3} / \mathrm{d}\right) / \mathrm{m}^{2}\right] \mathrm{m}$. In this report, the mathematically reduced form, meter squared per day $\left(\mathrm{m}^{2} / \mathrm{d}\right)$, is used for convenience. 


\title{
Hydrogeology of Puerto Rico and the Outlying Islands of Vieques, Culebra, and Mona
}

\author{
By Fernando Gómez-Gómez, Jesús Rodríguez-Martínez, and Marilyn Santiago
}

\section{Introduction}

The regulatory agencies of the Commonwealth of Puerto Rico, in particular the Puerto Rico Department of Environmental and Natural Resources (PRDENR), are in need of easily accessible information that might help them to properly manage the groundwater resources of Puerto Rico and its outlying islands. This information would be preferentially presented as a series of hydrogeologic maps complemented with geologic cross sections and textual notes. Consequently, the Commonwealth requested the U.S. Geological Survey (USGS) to prepare a report including the main elements of the hydrogeology of Puerto Rico and the outlying islands of Vieques, Culebra, and Mona obtained from previous studies conducted by the USGS.

The hydrogeologic maps of Puerto Rico and the outlying islands will be useful to hydrogeologists, groundwater specialists, and water-resources managers and planners in developing and protecting water resources in these islands. In addition, these maps can serve as catalysts in promoting future research within areas where current hydrogeologic information is limited or insufficient and can contribute toward promoting scientific interaction between countries in the Caribbean region.

Hydrogeologic maps were prepared for Puerto Rico and the outlying islands of Vieques, Culebra, and Mona by using a geographic information system (GIS) format. The hydrogeologic map of Puerto Rico is shown on plate 1 at a scale of 1:240,000. The hydrogeologic maps of the outlying islands are shown on plate 2 for Vieques, Culebra, and Mona at a scale of 1:50,000.

The principal objective of the hydrogeologic maps of Puerto Rico and the outlying islands of Vieques, Culebra, and Mona is to present information regarding the hydrogeologic and hydrologic characteristics of the islands in relation to specific geologic settings. Two primary features are depicted on the hydrogeologic maps. The first feature identifies geographic areas underlain by locally important aquifers as well as areas where groundwater availability is limited to nonexistent. The second feature differentiates groundwater occurrence according to the principal water-bearing units that compose the aquifers. Waterbearing units are depicted on the map as fissured units (carbonate rocks), intergranular deposits (alluvial or associated deposits), or a combination of both (Struckmeiser and Margat, 1995).

\section{Previous Work}

The first hydrogeologic map of Puerto Rico including the outlying islands of Vieques, Culebra, and Mona was prepared in 1965 by the U.S. Geological Survey (USGS) at a scale of 1:240,000 (Briggs and Ackers, 1965). At that time, available hydrogeologic information depicted on the map included

1. Information from surficial geologic maps prepared at various scales, such as 1:20,000 and smaller.

2. Information on well characteristics and drillers' lithologic logs.

3. Information obtained from the report "A comprehensive assessment of the groundwater resources of Puerto Rico and the outlying islands" (McGuinnes, 1948).

The 1965 hydrogeologic map of Puerto Rico was used as the basis for constructing the hydrogeologic maps presented in the current report. The 1965 map was especially useful in helping delineate the hydrogeologic unit boundaries described on the current maps. Information from a geologic map prepared by R.D. Krushensky (Bawiec, 1998) was also used.

The USGS has conducted numerous hydrologic and hydrogeologic investigations in cooperation with agencies of the Commonwealth of Puerto Rico since 1965. In addition, by 1987, the USGS was operating a network of 43 streamflowgaging stations, 56 surface-water-quality monitoring stations, and 31 groundwater-level monitoring sites throughout Puerto Rico (Curtis and others, 1987). By 2010, the network had expanded to include 88 streamflow-gaging stations, 55 surface-water-quality stations, and 92 groundwater-level monitoring sites (U.S. Geological Survey, 2010). Results from interpretive studies have been made available to the public in published reports and maps. Data have been made available through the Water Resources Data report series, published annually from 1965 to 2011, and most recently in digital format. Many reports on the water resources of Puerto Rico and the islands of Vieques, Culebra, and Mona have been published (http://pr.water.usgs.gov/publications/). Only those reports available through 2002 served as the primary sources of information in developing the recent hydrogeologic maps and preparing this report. 
Most of the information presented on the recent maps and in this report were derived from the federally funded USGS Caribbean Islands Regional Aquifer-System Analysis (CI-RASA) Program. Thus, readers are encouraged to review the reports prepared as part of that Program and other information available to the general public from the USGS National Water Information System (http://pr.water.usgs.gov/).

\section{Methodology Used to Prepare the Hydrogeologic Maps}

The hydrogeologic maps of the main island of Puerto Rico and the outlying islands were developed by reviewing available hydrologic and hydrogeologic data up to about 2002. An exception was the data provided on water use and groundwater withdrawals, which were estimated from 2005. The hydrogeologic data were summarized and interpreted in a format that could be understood by non-specialists as well as groundwater hydrology and water-resources specialists. The steps taken to prepare the hydrogeologic maps follow:

1. Existing literature was reviewed to determine those aquifer areas that had been studied in detail versus those aquifer areas that had been studied only as part of regional assessments.

2. Automated and non-automated databases were searched to compile information on well characteristics, the quality of groundwater, and streamflow statistics.

3. Geographic areas with deficient information were delineated. Missing information was obtained either by directly contacting government agencies that had collected groundwater data in those areas or by performing actual field surveys.

4. Preliminary maps and figures were constructed in preparation for developing the hydrogeologic map for the island of Puerto Rico and outlying islands.

5. Individual map overlays were reviewed for qualityassurance purposes and to make modifications where necessary prior to completing the final map plates.

\section{Generalized Characteristics of the Islands}

Puerto Rico and its adjacent islands of Vieques, Culebra, and Mona lie along the northeastern boundary of the Caribbean Sea between latitudes $17^{\circ} 58^{\prime} \mathrm{N}$. and $18^{\circ} 32^{\prime} \mathrm{N}$. and between longitudes $65^{\circ} 15^{\prime} \mathrm{W}$. and $68^{\circ} 00^{\prime} \mathrm{W}$. (fig. 1). The total land area of the four islands is 8,927 square kilometers $\left(\mathrm{km}^{2}\right)$-Puerto Rico is $8,713 \mathrm{~km}^{2}$, Vieques is $132 \mathrm{~km}^{2}$, Culebra is $30 \mathrm{~km}^{2}$, and Mona is $54 \mathrm{~km}^{2}$. In 2010, the total population of Puerto Rico (including Vieques and Culebra) was 3,725,789 with approximately 50 percent of the population living at or in the vicinity of the two major urban centers on the main island of Puerto RicoSan Juan to the north and Ponce to the south (fig. 1). Specifically, the population was distributed among the four islands as follows: Puerto Rico had 3,714,670 inhabitants; Vieques had
9,301 inhabitants; Culebra had 1,818 inhabitants; and Mona had no permanent inhabitants (U.S. Bureau of the Census, 2012).

The economic and social settings of Puerto Rico have been transformed substantially since World War II. Originally an agriculturally dependent economy based on sugarcane, tobacco, and coffee, Puerto Rico's economy has since become more diversified. The principal forces driving the island's economy include industrial development (in other words, pharmaceuticals and chemical products, electronics, textiles, and food processing); construction (i.e., industrial, commercial, residential, and public works infrastructure); commerce (i.e., retail sales and exports); financial services (i.e., banking); and tourism. The successful diversification of the economy beyond agriculture has been confirmed by labor statistics. In 2000, the total labor force consisted of 915,882 persons of which about 1 percent $(10,300)$ worked in agriculture or related enterprises. The remaining labor force was employed in management (27 percent) service, including government (16 percent), sales (28 percent), production and transportation (16 percent), and construction (12 percent) (http://www.dol.gov/ ofccp/pdf/reveeopr2.pdf). In 2007, the total labor force consisted of 1,014,970 persons of which less than 1 percent $(10,000)$ worked in agriculture or related enterprises.

The economic and social settings of Vieques differ greatly from that of Puerto Rico. Until 1943, sugarcane cultivated within the coastal plain served as the principal source of income for the island's population. In 1943, the U.S. Navy occupied the island, using nearly 75 percent of the land for training purposes. In 2004, the U.S. Navy transferred most of the occupied land to the U.S. Fish and Wildlife Service and to the Municipality of Vieques.

On Culebra, during the period from 1943 to 1973, about 30 percent of the land was under the jurisdiction of the U.S. Navy. By 1973, the U.S. Navy ceased nearly all operations on the island, retaining only 25 hectares (ha) at Punta Flamenco. The remaining land was transferred to the Commonwealth of Puerto Rico under stipulations of U.S. Public Law 93-166, which established certain restrictions on future land uses. The restrictions were intended primarily to comply with requirements of the National Environmental Policy Act to protect endangered species. As a result, about 380 ha or 15 percent of the island was designated as a wildlife refuge for migrating species of birds and sea turtles, including the leather back and green turtles, which use most of the island's sandy beaches as nesting areas. The wildlife refuge is managed cooperatively by the Puerto Rico Department of Natural and Environmental Resources and the U.S. Fish and Wildlife Service. An additional 316 ha are to be retained by the U.S. Fish and Wildlife Service in exchange for about 108 ha of land on the adjacent island of Culebrita, which has been part of the U.S. National Wildlife Refuge system since 1909.

The entire island of Mona is protected as a sanctuary for 59 endemic plant and animal species and as a wildlife refuge for migrating species. A number of pre-Colombian archaeological sites and places of historical interest also are located on the island. 

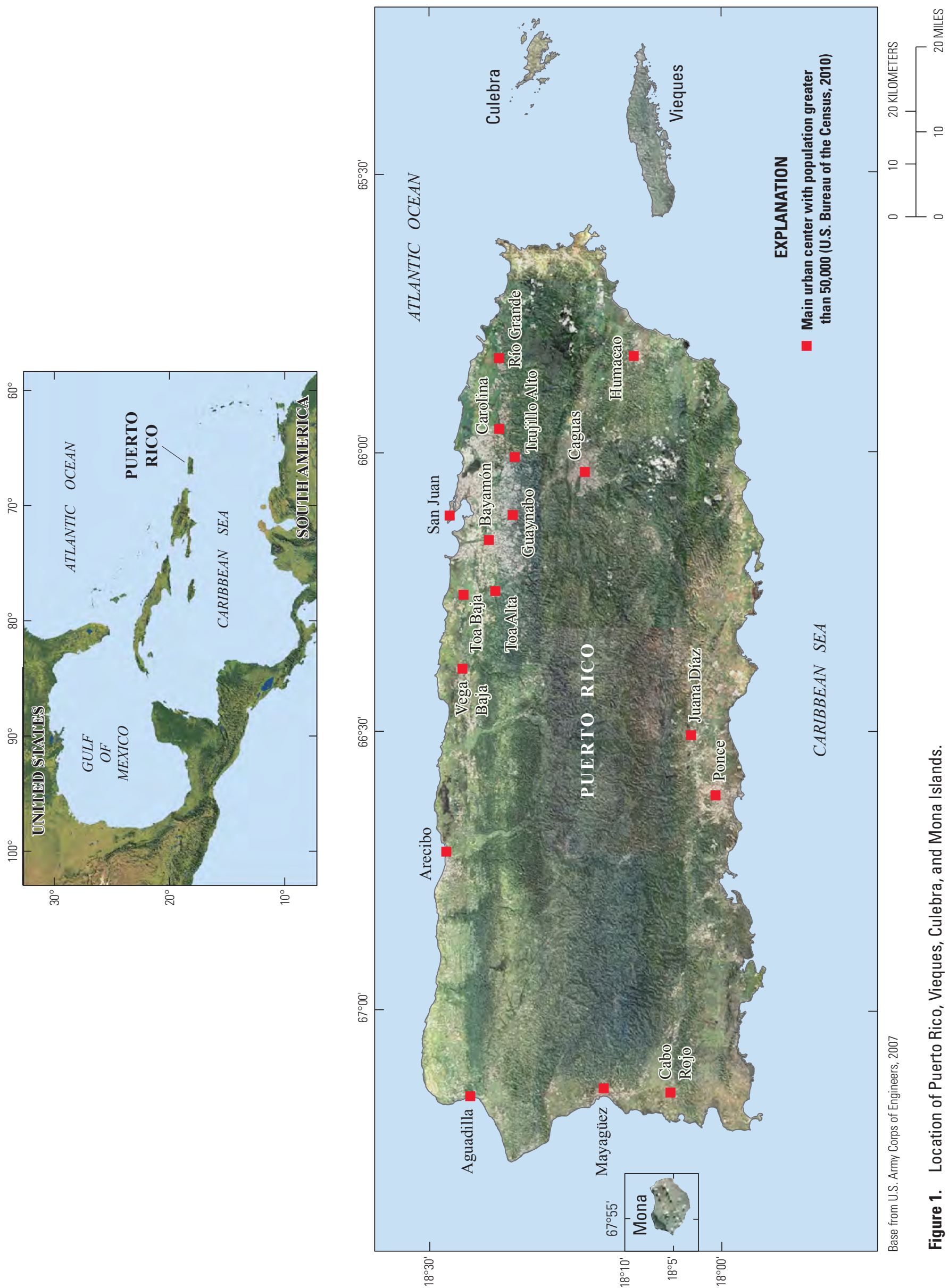


\section{Physiography and Vegetation}

Geographically, Puerto Rico and the outlying islands have been subdivided into 11 regions on the basis of similar landforms and climate characteristics (fig. 2; table 1; Picó, 1964). The physical diversity characterizing each region is complex and beyond the scope of this report; however, the following summary describes the primary physiographic features of each island.

\section{Puerto Rico}

The principal physiographic feature of Puerto Rico is the Cordillera Central and the Sierra de Cayey, which form a continuous mountain range extending in an east-west direction nearly the entire length of the island (fig. 3). The foothills, which separate the coastal plain from the mountains, begin at an altitude of about 300 meters (m). Throughout most of the mountainous areas, ridge tops reach altitudes of $700 \mathrm{~m}$ with a maximum altitude of $1,338 \mathrm{~m}$ found at Cerro de Punta north of Ponce. Within the mountainous areas, hillsides are steep with about 50 percent of the land having slopes greater than 45 percent.

The predominant physiographic feature characterizing the western two-thirds of the northern coast is karst terrain, which extends inland as much as 20 kilometers $(\mathrm{km})$. The karst topography varies from typical solution feature landforms, such as sinkholes and cockpits (intersecting star-shaped dolines or sinks), to residual tower karst features, which are landforms distinguished by elongated plains bounded by steep-sided hills or mogotes (haystack hills). In general, solution karst landforms are more typical of inland areas, and residual tower karst landforms predominate at lower altitudes along the north coast (Monroe, 1976). The most distinctive feature along the south coast of Puerto Rico is the marked contrast between the intense green foliage of cultivated crops grown on irrigated lands within the coastal plain and alluvial valleys and the semi-arid conditions and sparse vegetation growing within the foothills and karst terrain of the southwest.

\section{Vieques}

The principal physiographic feature of Vieques is a relatively broad plain that slopes to the south from a central ridge extending across the western half of the island (fig. 4). Altitudes along most of the length of the ridge reach $100 \mathrm{~m}$ with a maximum altitude of $301 \mathrm{~m}$ at Monte Pirata. The land has a slope of about 12 percent between an altitude of $50 \mathrm{~m}$ and the coast. Above this altitude, the slope increases to about 40 percent. As of 2002, most of the island was in pasture or brush.
Table 1. Geographic regions of Puerto Rico (modified from Picó, 1964).

[Areas adjusted to agree with that given in U.S. Bureau of the Census, 1991; areas exclude off-shore cays and islets]

\begin{tabular}{|c|c|c|}
\hline Geographic region & Hectares & $\begin{array}{l}\text { Percent of } \\
\text { total area }\end{array}$ \\
\hline 1. North Coastal Plain & 119,395 & 13.4 \\
\hline A. Sub-humid western area & 33,377 & \\
\hline B. Humid alluvial area & 86,018 & \\
\hline 2. Humid Valleys of the East Coast & 27,800 & 3.1 \\
\hline A. Fajardo area & 9,864 & \\
\hline B. Naguabo-Humacao valleys & 11,365 & \\
\hline C. Yabucoa valley & 4,939 & \\
\hline D. Maunabo valley & 1,632 & \\
\hline 3. Caguas Valley & 12,868 & 1.4 \\
\hline 4. Valleys of the West Coast & 23,208 & 2.6 \\
\hline A. Culebrinas-Culebras valleys & 4,217 & \\
\hline B. Córcega area & 462 & \\
\hline C. Añasco valley & 4,665 & \\
\hline D. Guanajibo valley & 13,864 & \\
\hline 5. South Coastal Plain & 87,779 & 9.8 \\
\hline A. Ponce-Patillas Coastal Plain & 47,067 & \\
\hline B. Tallaboa valley & 2,210 & \\
\hline C. Guayanilla-Guánica area & 6,080 & \\
\hline D. Lajas valley & 13,763 & \\
\hline E. Southwest mountain belt & 18,659 & \\
\hline 6. Semi-arid southern foothills & 88,270 & 9.9 \\
\hline 7. Humid Northern Foothills & 185,956 & 20.8 \\
\hline A. Cretaceous northeast area & 66,549 & \\
\hline B. Interior Limestone belt & 95,852 & \\
\hline C. Atalaya mountains & 23,555 & \\
\hline 8. Humid Mountains of the East & 133,561 & 15.0 \\
\hline 9. Rainy Mountains of the West & 171,168 & 19.2 \\
\hline 10. Sierra de Luquillo & 21,331 & 2.4 \\
\hline 11. Vieques, Culebra, and Mona & 21,620 & 2.4 \\
\hline A. Vieques & 13,200 & \\
\hline B. Culebra & 3,000 & \\
\hline C. Mona & 5,420 & \\
\hline Total & 892,956 & 100.0 \\
\hline
\end{tabular}




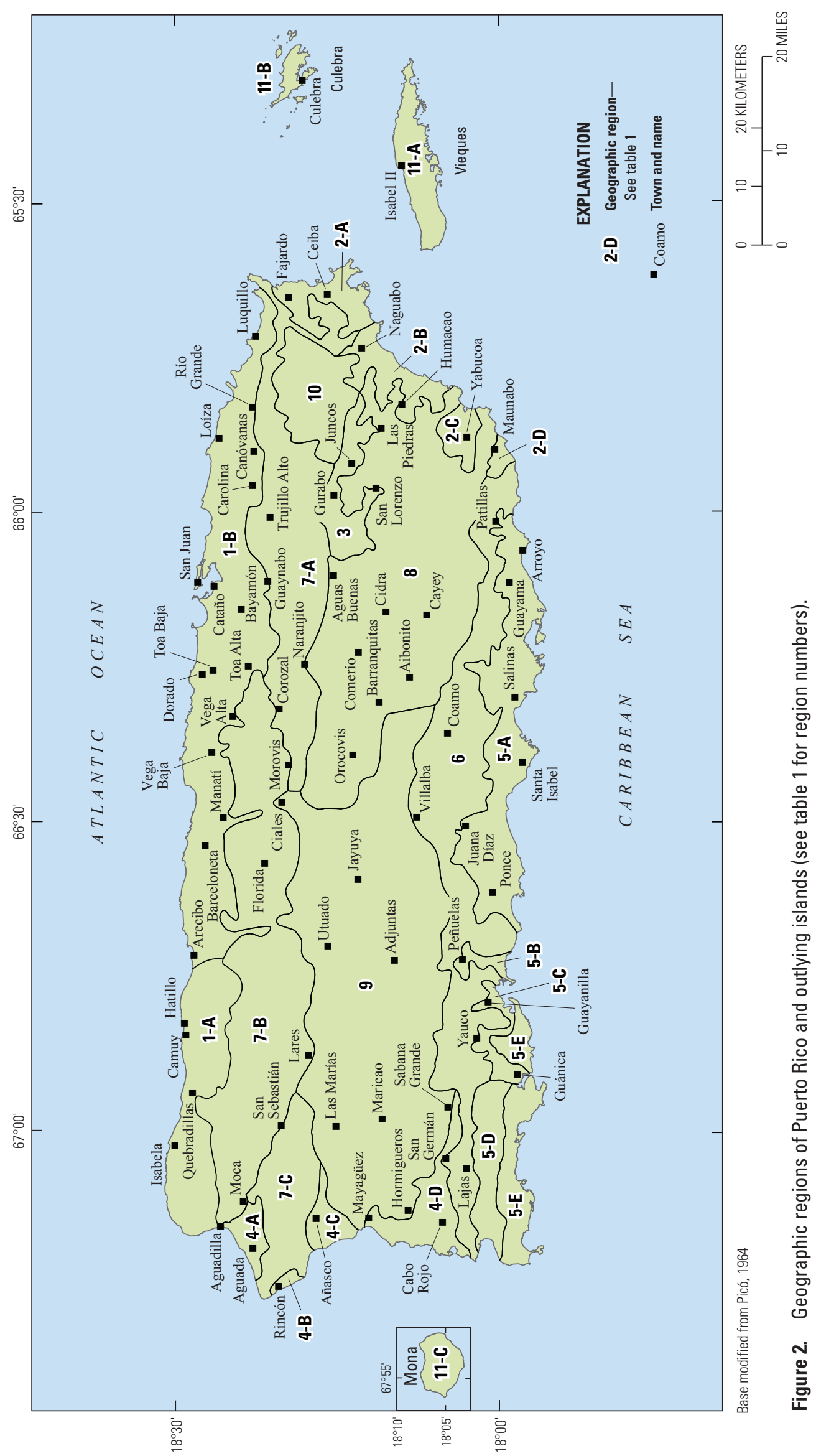




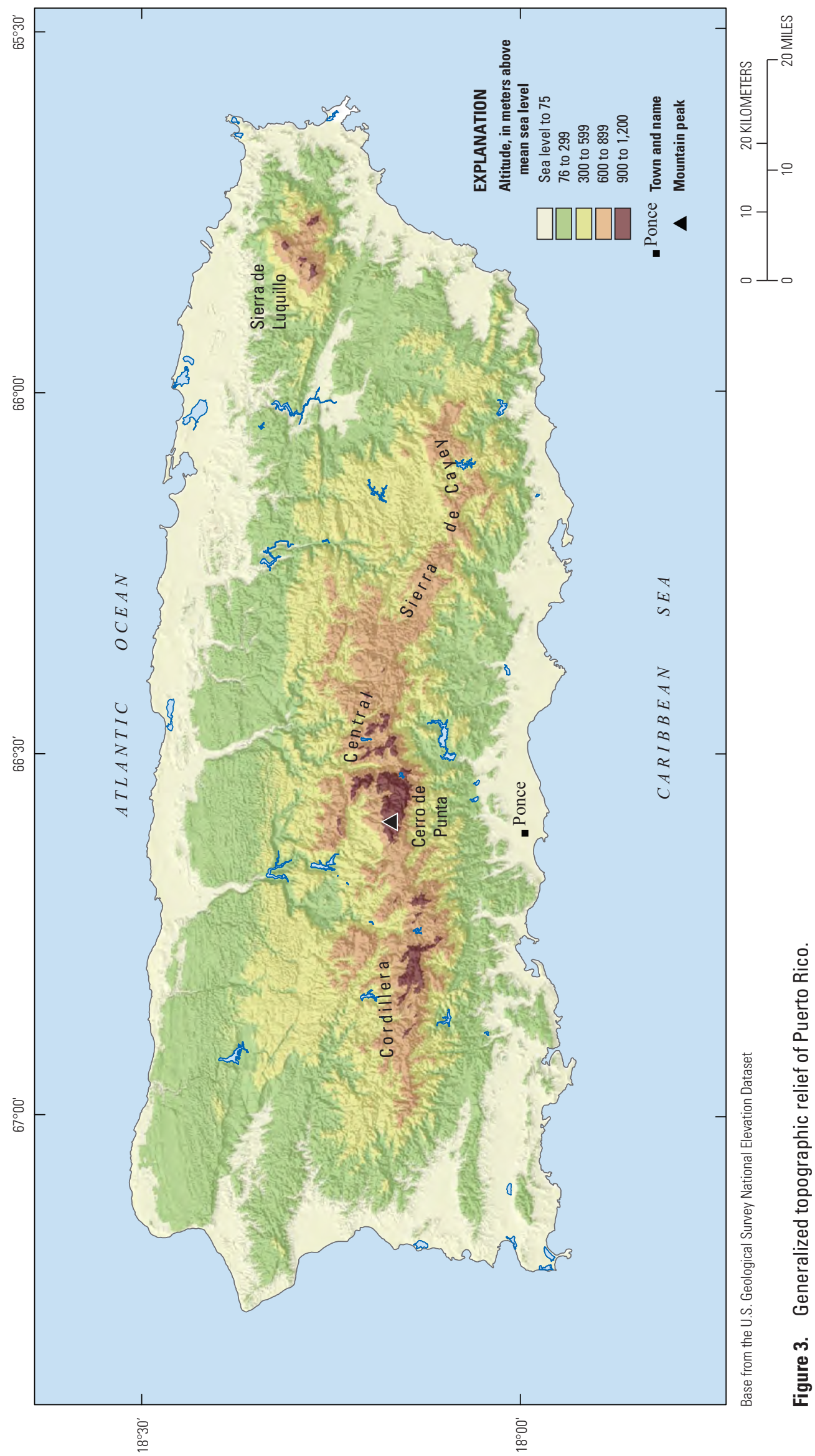




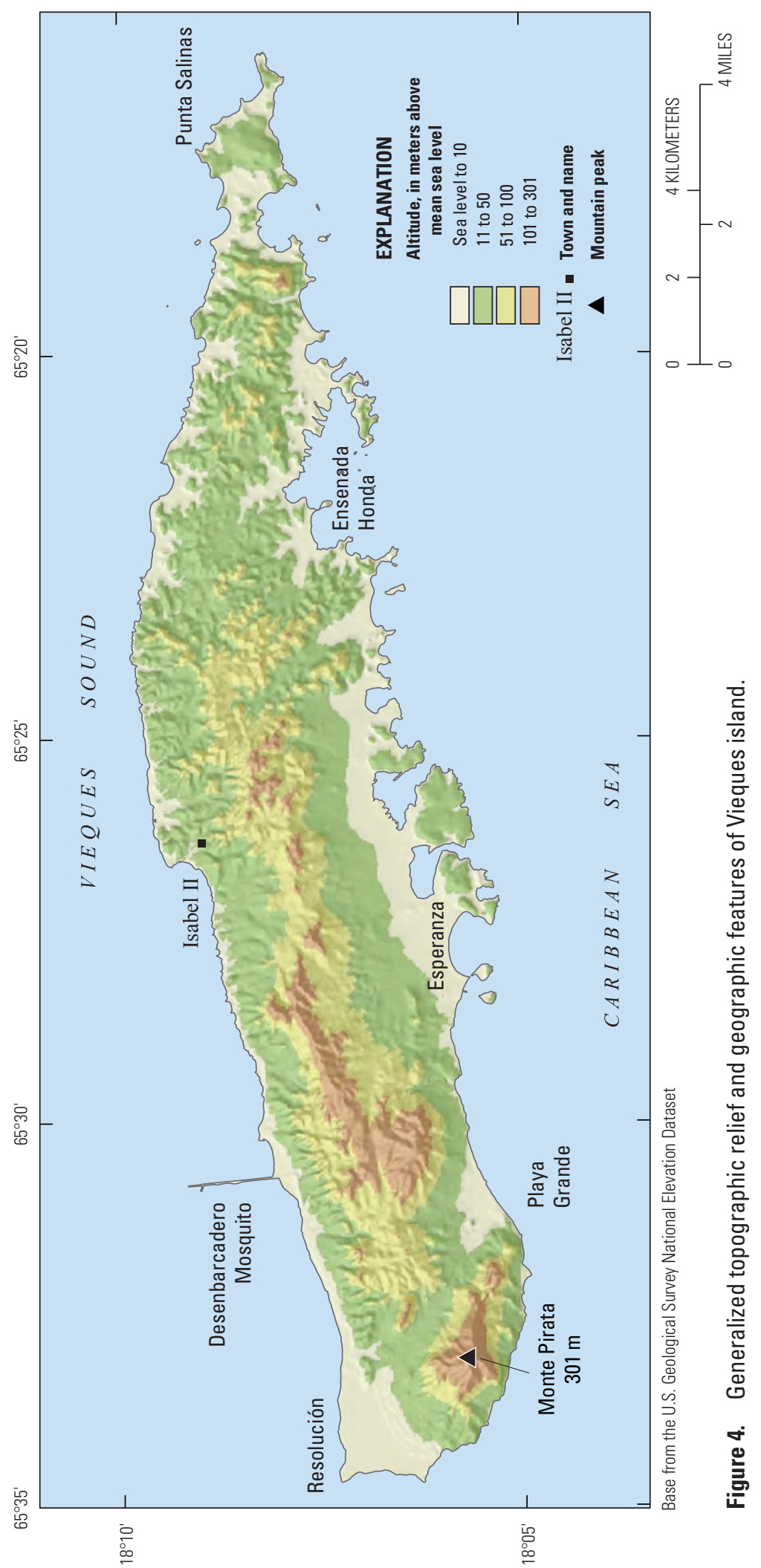




\section{Culebra}

The principal physiographic feature of Culebra is Ensenada Honda, which is a natural bay located on the south side of the island (fig. 5). The bay is sheltered from the trade winds and is about $12 \mathrm{~m}$ at its maximum depth. The terrain of Culebra is hilly with slopes ranging between 20 and 40 percent. As of 2002, most of the land was in pasture or brush.

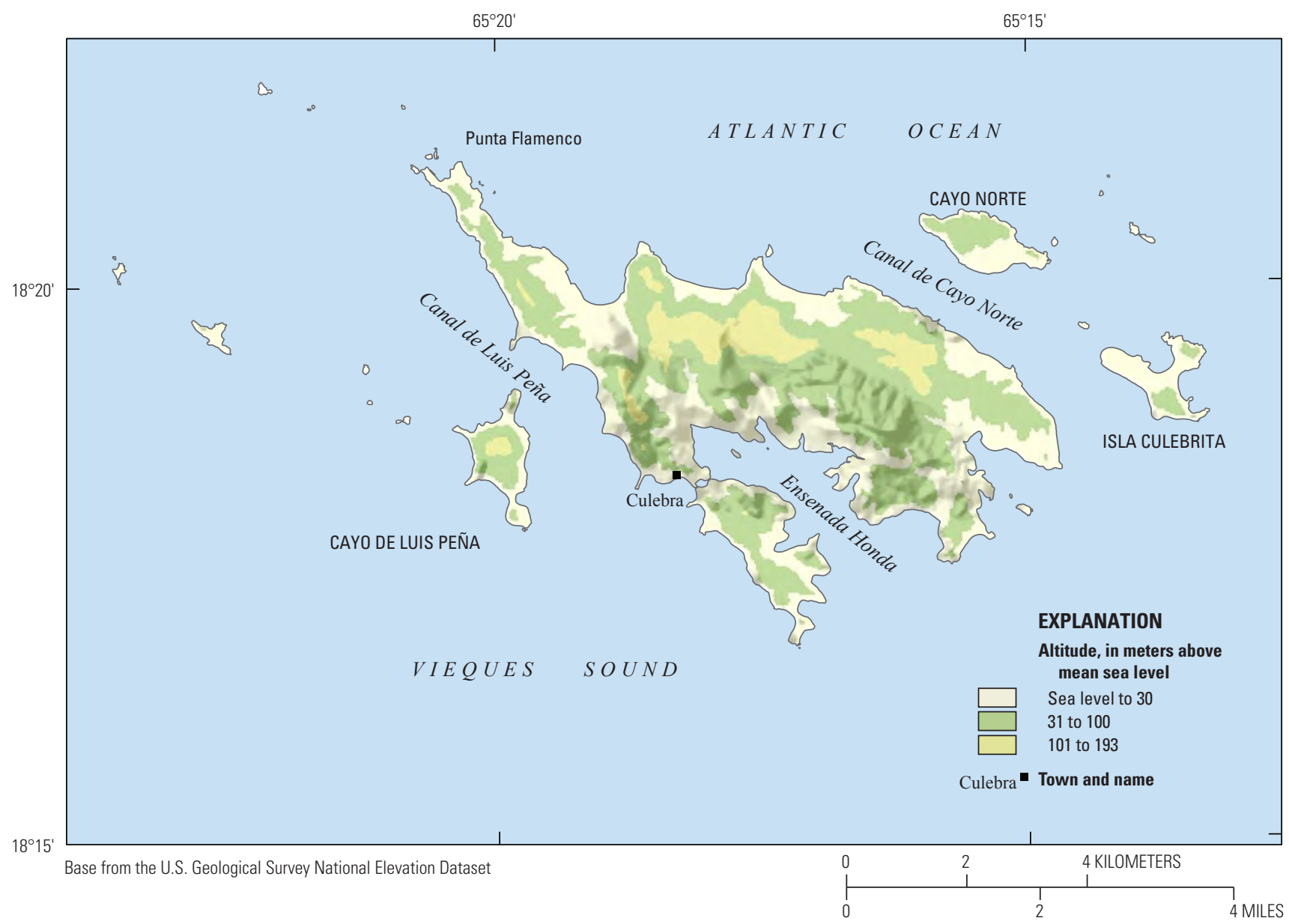

Figure 5. Generalized topographic relief and geographic features of Culebra island. 


\section{Mona}

Two physiographic features dominate the landscape of Mona (fig. 6). First, the island is encircled by cliffs that rise vertically upward from the ocean along more than 50 percent of the coastline. Second, the interior of the island is characterized by a limestone tableland that reaches an average altitude of $60 \mathrm{~m}$. The tableland is nearly flat, with the exception of sinkhole depressions in an area covering less than 170 ha. The sinkhole depressions are the only areas on the island where soil is found, with the exception of the coastal plain. The reddish silt loam derived from weathering of the limestone bedrock fills the depressions and provides support for a forest of trees that average $6 \mathrm{~m}$ in height. The only other forest vegetation on the island is located within a 320-ha tract of land on the coastal plain. The remainder of the island vegetation is predominantly low dry forest shrubs and cactus.

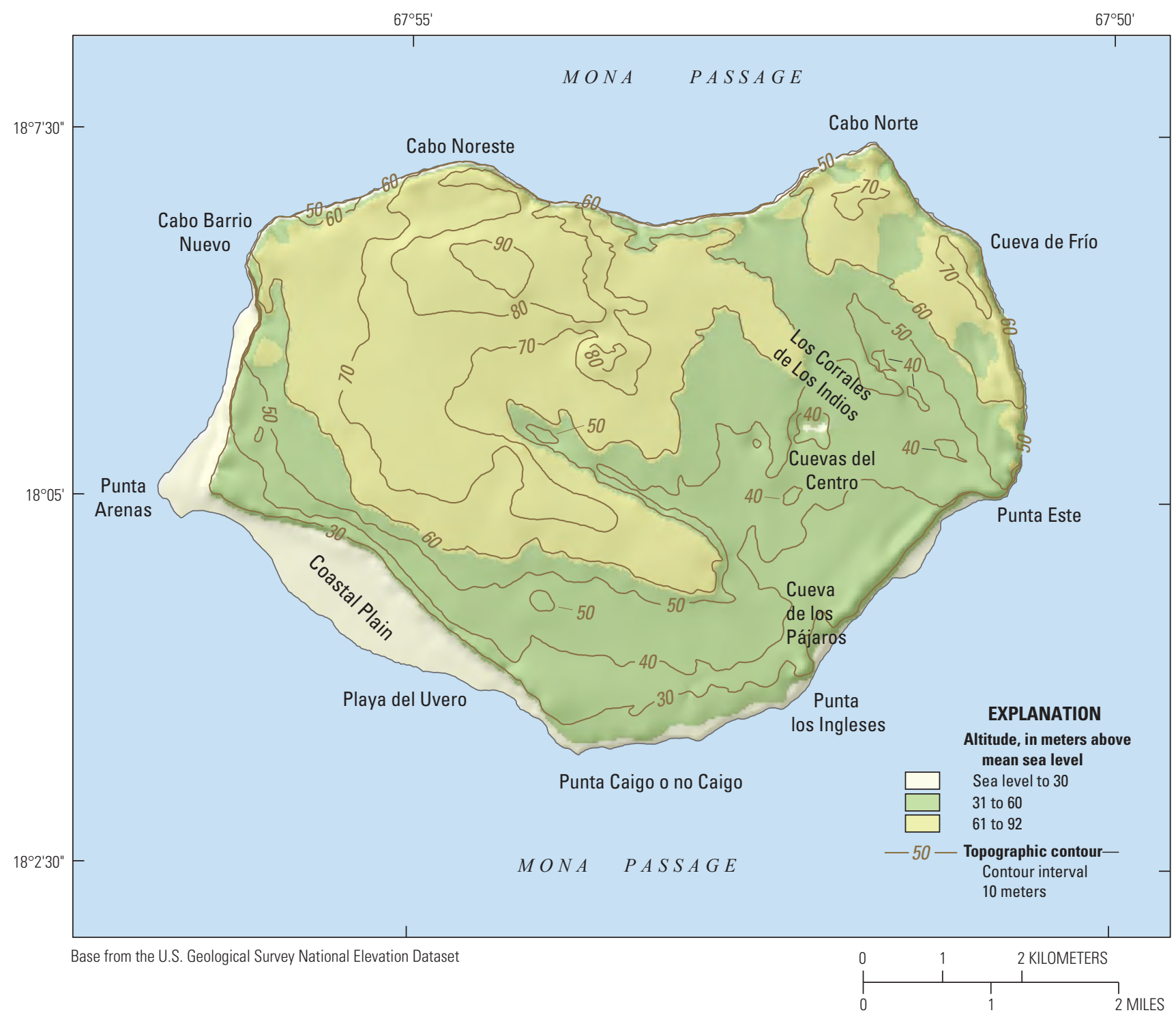

Figure 6. Generalized topographic relief and geographic features of Mona island. 


\section{Climate}

In general, the east-west trending Cordillera Central and Sierra de Cayey mountains form an insular hydrologic divide that separates the island of Puerto Rico into two climatologically distinct regions. The northern two-thirds of the island has a relatively humid climate whereas the southern one-third of the island is semi-arid.

The National Oceanic and Atmospheric Administration (1982) subdivided the island of Puerto Rico into six climate areas and designated a seventh climate area in the outlying islands (fig. 7). Local climate variability within each subdivision and in the outlying islands is attributed to local differences in topographic relief and the effect of prevailing trade winds. Along the northern coast of Puerto Rico and in the outlying islands, prevailing trade winds are from the northeast. Along the southern coast of Puerto Rico, the east-west trending mountains affect wind patterns. In this area, the predominant wind direction is from the southeast during daylight hours, whereas prevailing winds are from the northeast during the period from midnight to early morning. Prevailing winds along the western end of Puerto Rico at Mayagüez differ from other areas on the island. Predominant winds in this area are from the west, which is nearly opposite to the prevailing northeast trade winds. Prevailing west winds are infrequent throughout other areas of the island. For example, in the San Juan area, west prevailing winds occur less than 3 percent of the time and generally are associated with the passing of cold fronts across the island.

Mean monthly air temperatures in Puerto Rico and the outlying islands vary little throughout the year. Air temperatures generally are warmest during the month of August and coolest during the months of January and February. In coastal areas, annual air temperatures range from a mean maximum of 27 degrees Celsius $\left({ }^{\circ} \mathrm{C}\right)$ to a mean minimum of $24^{\circ} \mathrm{C}$. In interior mountainous areas (that is, Eastern and Western Interior climate subdivisions; fig. 7), annual air temperatures range from a mean maximum of $25^{\circ} \mathrm{C}$ to a mean minimum of $22^{\circ} \mathrm{C}$.

Air temperatures fluctuate little throughout the year as a result of relatively constant insolation (that is, solar radiation) and seawater temperatures. The rate of delivery of solar radiation is nearly constant because the difference in daylight hours varies little throughout the year. Between the longest day of the year (13 hours, 13 minutes) and the shortest day (11 hours, 2 minutes), the amount of daylight differs by only slightly more than 2 hours. Mean monthly seawater temperatures vary by only about $4{ }^{\circ} \mathrm{C}$; the mean maximum water temperature of $28^{\circ} \mathrm{C}$ occurs in October, and the mean minimum water temperature of $24^{\circ} \mathrm{C}$ occurs in January.
The spatial distribution of rainfall in Puerto Rico is variable (fig. 8). Rainfall is greatest in the Sierra de Luquillo rainforest in the eastern part of Puerto Rico. The mean annual total rainfall in Sierra de Luquillo is 4,305 millimeters per year $(\mathrm{mm} / \mathrm{yr})$. The least amount of rainfall occurs in the vicinity of Guánica at Ensenada in southwestern Puerto Rico. In this area, the mean annual total rainfall is $768 \mathrm{~mm} / \mathrm{yr}$.

Pronounced orographic effects from the Cordillera Central and the Sierra de Cayey mountains in Puerto Rico result in high rainfall amounts occurring on the windward side of the mountains, which is north of the insular hydrologic divide. The opposite occurs south of the divide on the leeward side of the mountains, where coastal areas lie within a rain shadow resulting in lower rainfall amounts. Orographic effects on rainfall are not as pronounced in the outlying islands, with the exception of Vieques.

Rainfall on the island of Vieques differs substantially between the leeward or west side of the island and the windward or east side of the island. In general, rainfall occurs more frequently on the west side of Vieques. Although rainfall data are insufficient to quantify amounts, estimates indicate that the difference in rainfall between the east and west ends of the island could be as much as $345 \mathrm{~mm} / \mathrm{yr}$. Rainfall in the eastern part of the island may be similar to that of the island of Culebra where the mean annual total rainfall is $925 \mathrm{~mm} / \mathrm{yr}$. The mean annual total rainfall in the western part of Vieques, at Playa Grande and Resolución, is 1,270 mm/yr (fig. 4). The mean annual total rainfall on the island of Mona is $915 \mathrm{~mm} / \mathrm{yr}$.

Although rainfall data are limited, certain vegetation adapted for life with a limited water supply (such as xerophytes) serve as strong indicators about rainfall distributions on Vieques. The growth of xerophytes is prevalent on the east side of the island where rainfall is limited as opposed to the west side of the island where rainfall is more abundant.

Major rainfall events producing substantial volumes of rain in Puerto Rico and the outlying islands are caused by one of two climate mechanisms - the passage of an easterly wave or the passage of a cold front. Easterly waves generally occur during May to November with some having sufficient intensity to evolve into tropical storms and (or) hurricanes. Cold fronts generally occur during November to April and may produce sufficient rainfall to cause flooding even during the period from December to March, which is a relatively dry period. The number of easterly waves or cold fronts passing over the region in any given year ultimately determines whether the region experiences relatively dry conditions or wet conditions. As a result, localized droughts occur yearly within many of the geographic areas of Puerto Rico. 


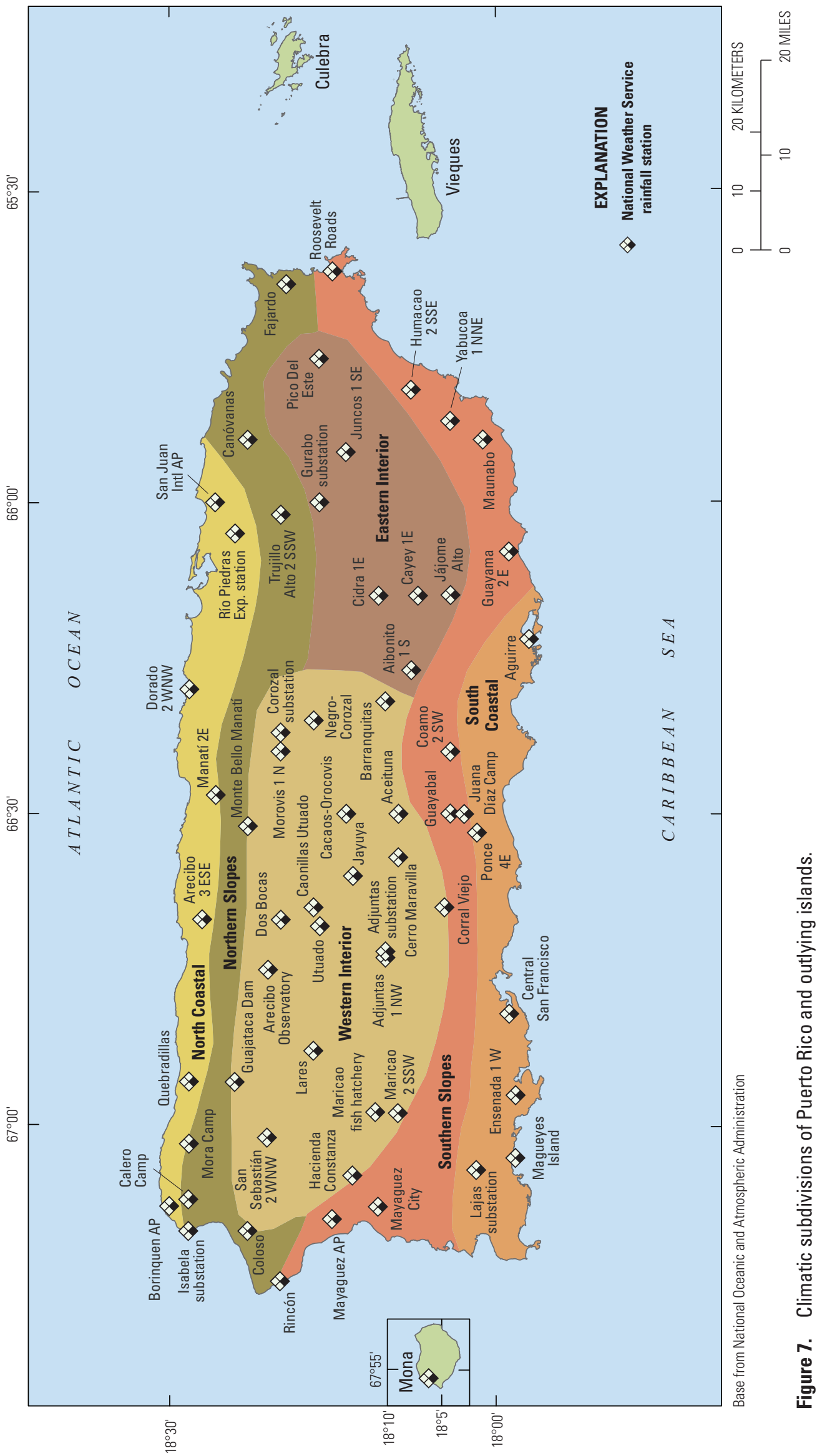




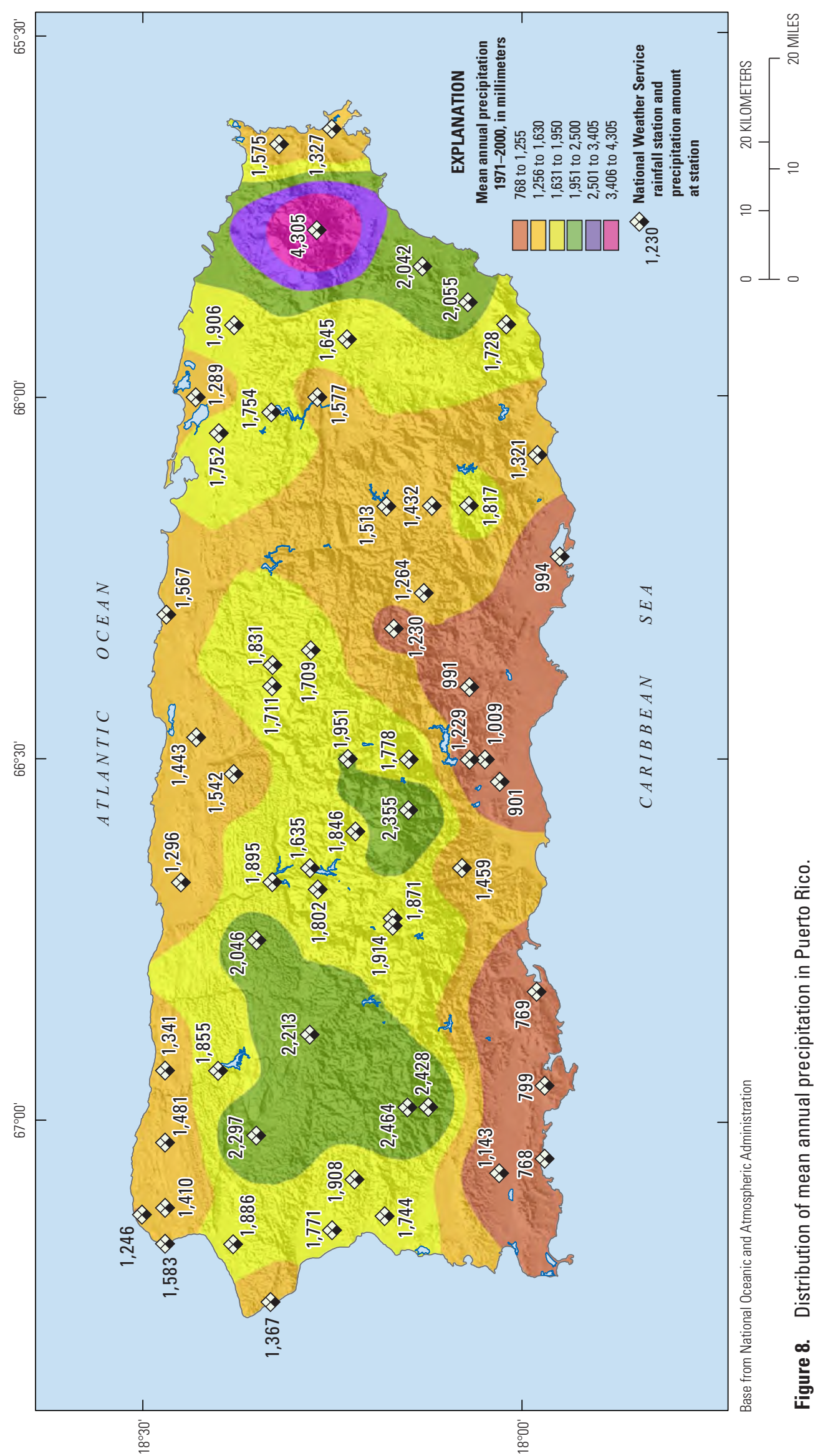


Extended, extreme drought conditions affecting the entire region of Puerto Rico and the outlying islands have occurred on three occasions during the 20th century. The first extreme drought began in the late 1920s and continued through 1930. The second severe drought began in the mid 1960s and ended in 1968. The third severe drought affected primarily the eastern half of the main island of Puerto Rico throughout most of 1994 (fig. 9). During the drought of the 1960s, mean annual rainfall on the main island of Puerto Rico was about 1,100 millimeters (mm) in 1967 (Colón, 1983) compared to the 30-year normal (1931-60) of 1,825 mm/yr. The drought of 1994 resulted in a rainfall deficiency of about 30 percent throughout the eastern part of the island and was particularly notable in its effect on the availability of public-supply water for more than 1 million people living within the San Juan metropolitan area and the city of Caguas. Historical references indicate that other severe droughts have reportedly affected the southern coast of Puerto Rico from Guayama to Cabo Rojo during the period 1892 to 1894 (Wilson, 1899) and during the period 1871 to 1874 . Evidence of the severity of this latter drought period was found in a decree written by the Ponce mayor, Rafael de Leon, on May 17, 1874. In the decree, the mayor reminded citizens of the law prohibiting the cutting of forested areas without first obtaining the proper permits in light of the severe drought, which affected the area for more than 3 years (Neumann, 1913).

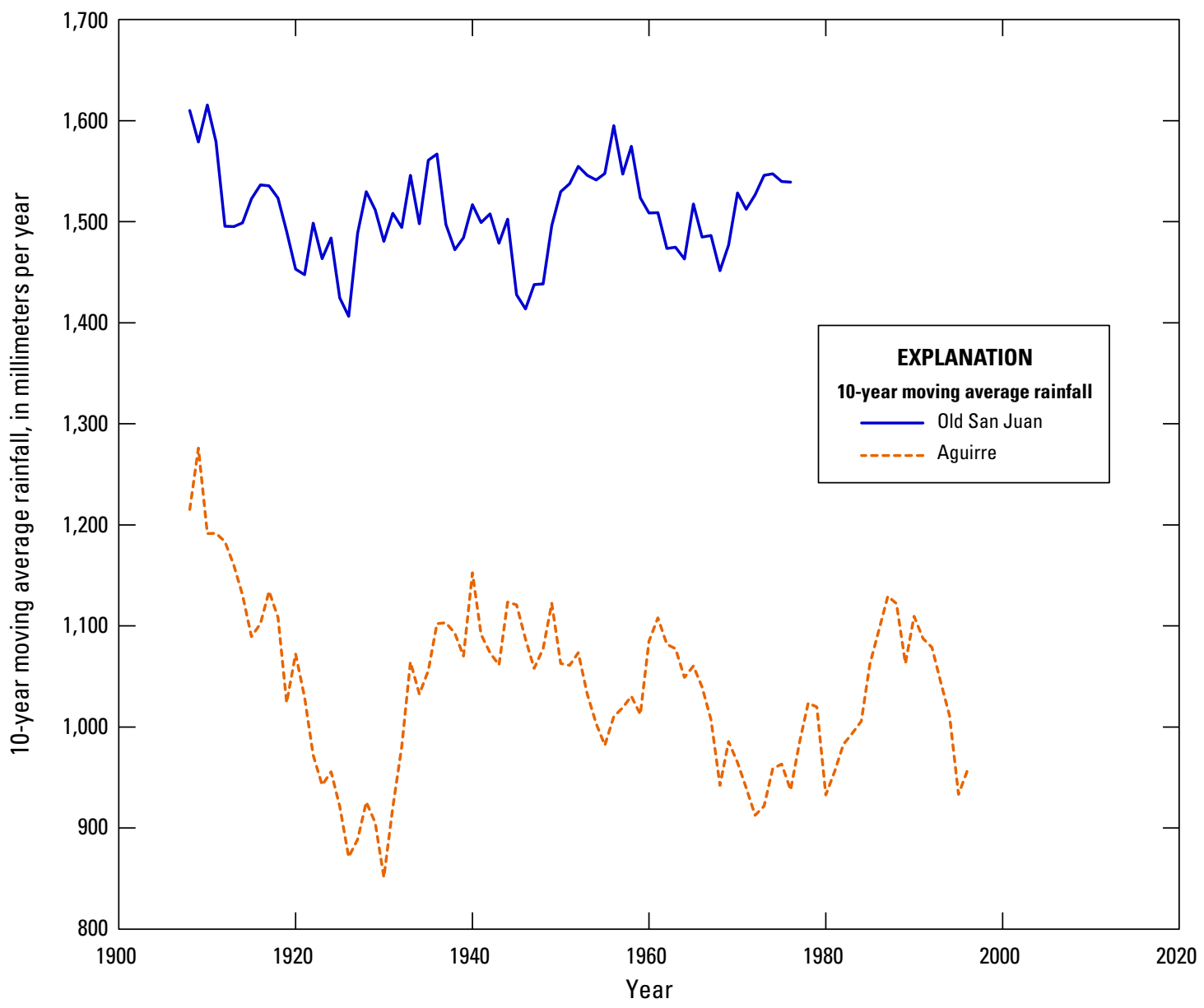

Figure 9. 10-year moving average rainfall trends at San Juan and Aguirre (66-0152), Puerto Rico (San Juan station (66-8808) at Old San Juan, discontinued in 1976). 


\section{Geology}

A generalized description of the geology of Puerto Rico and adjacent islands is presented below. Information was obtained from reports compiled by Bogart and others (1964) and from studies conducted by Meyerhoff (1933), Zapp and others (1948), Mattson (1960), Briggs (1961), Glover (1971), and Monroe (1980). During the late 1980s, an extensive exploratory drilling program was conducted within the largest aquifer systems in northern and southern Puerto Rico. Thousands of meters of cores from 15 locations along the northern coast were used by Hartley (1989) and Scharlach (1990) for interpretation of the stratigraphy and depositional history of the Oligocene and Miocene rocks. Along the southern coastal plain, exploratory drilling was also conducted in the area from Ponce to Salinas. Core data were used to describe the depositional history within the fan-delta plain and the relation of the plain to tectonic and eustatic sea level changes (Renken and others, 1995). Details of the updated interpretations of the island's geologic framework and the relation of the geology to the hydrogeologic setting are presented in Renken and others (2002).

The central core of Puerto Rico consists primarily of volcanic and intrusive rocks of Cretaceous and early Tertiary age (fig. 10). The volcanic rocks are predominately ashy shale, agglomerate, and tuff, and most of them are thoroughly indurated. These rocks are interbedded with thick, dense lava flows and relatively thin beds of limestone that have been partly recrystallized in many places. The volcanic rocks and interbedded limestones have been complexly faulted, folded, metamorphosed, and intruded by dioritic rocks. The massive, dense dioritic intrusions are exposed by erosion in two large areas and many small areas on the island (plate 1). Massive, dense serpentinite and associated silicified rocks underlie large areas in the southwestern part of the island (plate 1). The central igneous core of the island is flanked on the north and south by clastic sediments and limestones of Oligocene and Miocene age.

Within the middle Tertiary sequence, the older clastic sediments are composed predominately of poorly sorted mixtures of gravel, sand, and finer materials. The sediments grade upward into thick beds of relatively pure limestone.
Along the northern coast, the limestone has been subjected to extensive solutional activity, which has resulted in the formation of mature karst topography. Unconsolidated deposits of Pleistocene and Holocene age form a discontinuous coastal plain. The sediments throughout most parts of the north and northeast consist mostly of carbonaceous sandy clay, except at the stream valleys where the sediments grade inland to alluvial deposits. At the western coast stream valleys, the deposits are derived from weathered tuff and shale and consist mostly of clay and silt. Alluvium deposited at the southern and southeastern coasts is rich in coarse-grained sand and gravel except near the shoreline where it grades into swamp deposits. After the deposition of limestone during the middle Tertiary period, Puerto Rico was arched, uplifted, and tilted to the northeast. The islands of Vieques and Culebra are part of the Puerto Rican block and are separated from Puerto Rico by the submergence that resulted from the tilting to the northeast and by the eustatic increase in sea level during the Holocene period.

Vieques island is underlain in the eastern half by andesites of Late Cretaceous age deposited in a marine environment and in the western half by an extensive dioritic rock intrusion (fig. 10). Limestones of Miocene age fringe the southern coast and the extreme eastern end of the island, and deposits of alluvium as much as $20 \mathrm{~m}$ thick form a relatively extensive plain toward the southwest. Culebra island is underlain by volcanic and intrusive rocks of Cretaceous age. In the northcentral part, these rocks have been intruded by diorite. Alluvial deposits are predominately composed of silt and clay, but in the major stream courses near the coast these deposits contain some sand and gravel. Mona island is a limestone plateau, bounded by steep to vertical cliffs that rise $60 \mathrm{~m}$ above mean sea level. Except for a thin soil cover present only in large upland depressions, the entire island consists of limestone and calcitic dolomite. Two major units have been identified; from oldest to youngest these are the Isla de Mona Dolomite of early or middle Miocene age, with a maximum exposed thickness of $80 \mathrm{~m}$ (base concealed by the sea), and the Lirio Limestone of Miocene age, with a maximum exposed thickness of $40 \mathrm{~m}$ (Kaye, 1959). A narrow, low-lying coastal terrace exists along the southern perimeter of the island formed by an elevated reef of Pleistocene age with a thin cover of sand. 


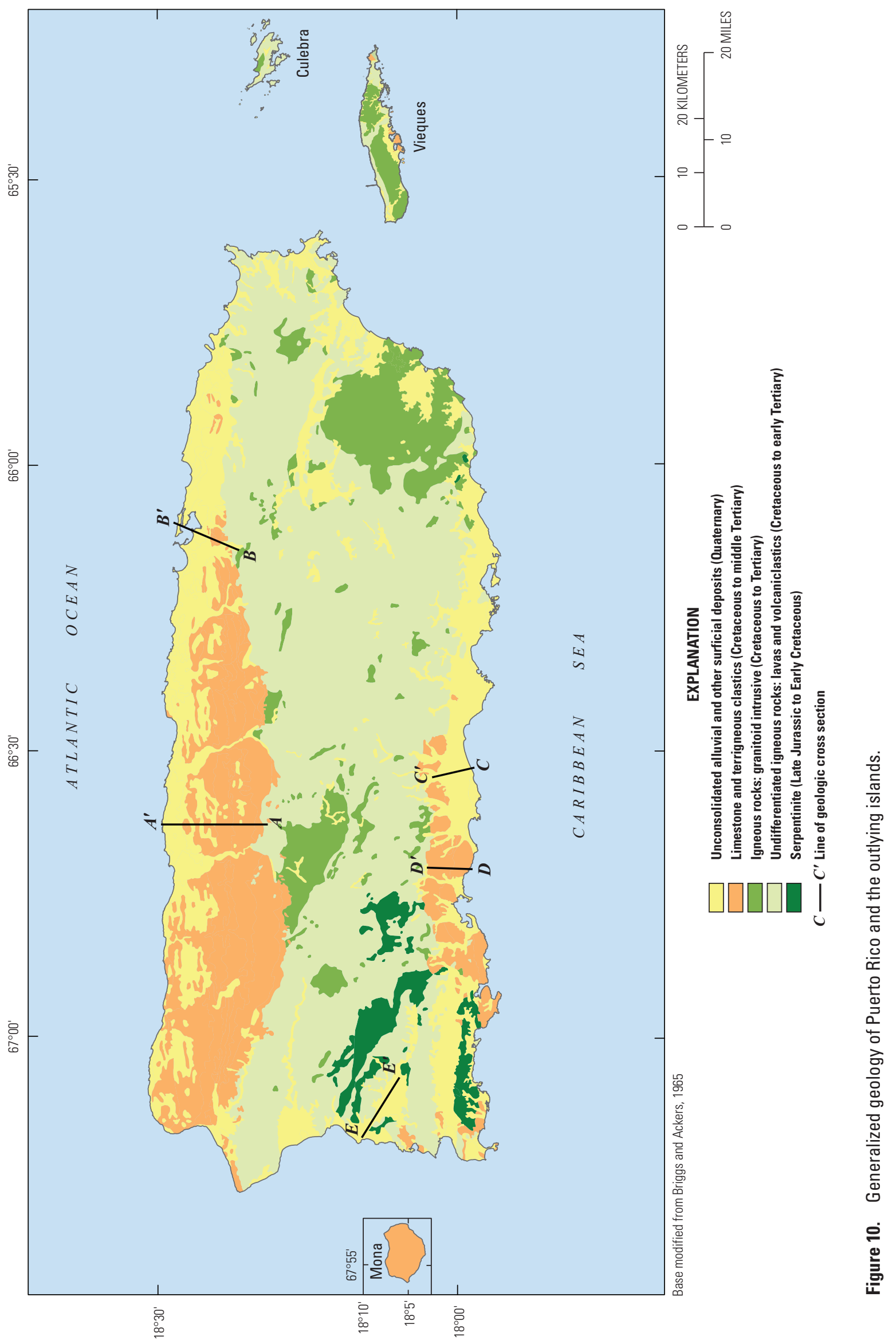




\section{Hydrology}

The island of Puerto Rico is considered to have an abundant supply of water compared to the smaller islands of Vieques, Culebra, and Mona. On the main island, about 41 perennial streams discharge to the sea (fig. 11). All of the perennial streams are located north of the Cordillera Central mountains, except the Río Guanajibo and Río Grande de Añasco, which are located in the southwestern and western parts of Puerto Rico, respectively. The longest river is the Río de la Plata, which has a total length of $100 \mathrm{~km}$ and discharges to the west of San Juan. The headwaters of the Río de la Plata are in the Sierra de Cayey (the eastern extension of the Cordillera Central) at an altitude of $700 \mathrm{~m}$. The largest stream basin is the Río Grande de Loíza in northeastern Puerto Rico; the basin covers about $750 \mathrm{~km}^{2}$. Additional information about the principal watersheds in Puerto Rico is listed in table 2.

Table 2. Basic streamflow statistics for selected gaging stations in Puerto Rico.

$\left[\mathrm{km}^{2}\right.$, square kilometers; $\mathrm{m}^{3} / \mathrm{s}$, cubic meters per second; $\mathrm{m}^{3} / \mathrm{d}$, cubic meters per day]

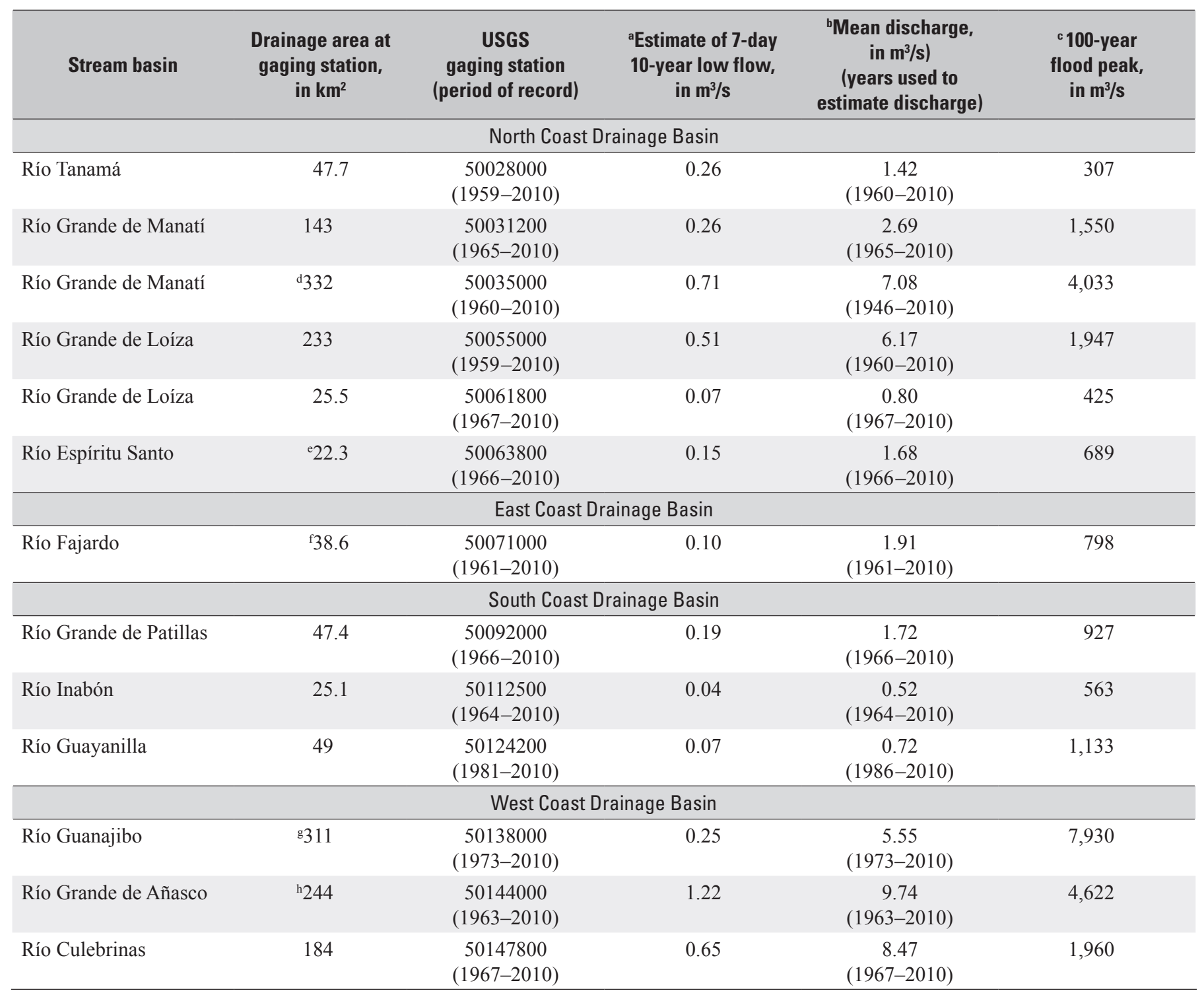

a'Low-flow values from Santiago-Rivera (1992, 1996, 1998).

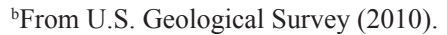

cValues from Ramos-Ginés (1999).

${ }^{\mathrm{d}}$ About 29,000 $\mathrm{m}^{3} / \mathrm{d}$ diverted for public supply upstream of gaging station; area excludes $15.5 \mathrm{~km}^{2}$ diverted to south coast from Lago Guineo and Lago de Matrullas.
${ }^{\mathrm{e}}$ About $2,800 \mathrm{~m}^{3} / \mathrm{d}$ diverted for public supply upstream of gaging station. ${ }^{\mathrm{f}}$ About $28,000 \mathrm{~m}^{3} / \mathrm{d}$ diverted for public supply upstream of gaging station. ${ }^{\mathrm{g}}$ About $16,000 \mathrm{~m}^{3} / \mathrm{d}$ diverted for public supply upstream of gaging station.

${ }^{\mathrm{h}}$ Area excludes $103 \mathrm{~km}^{2}$ diverted to south coast by dams at Lago Yahuecas, Lago Guayo, Lago Prieto, and Lago Toro. 


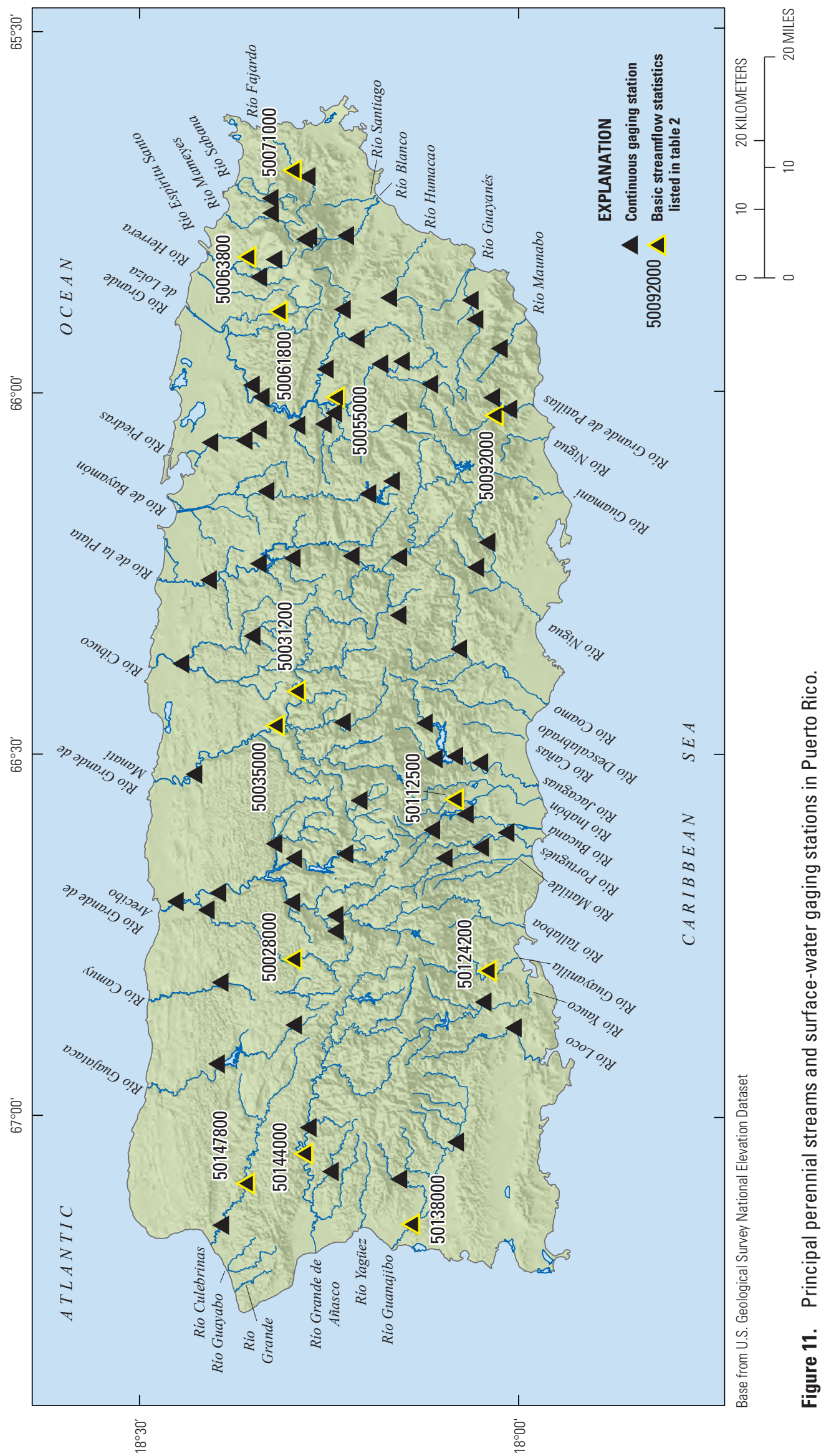




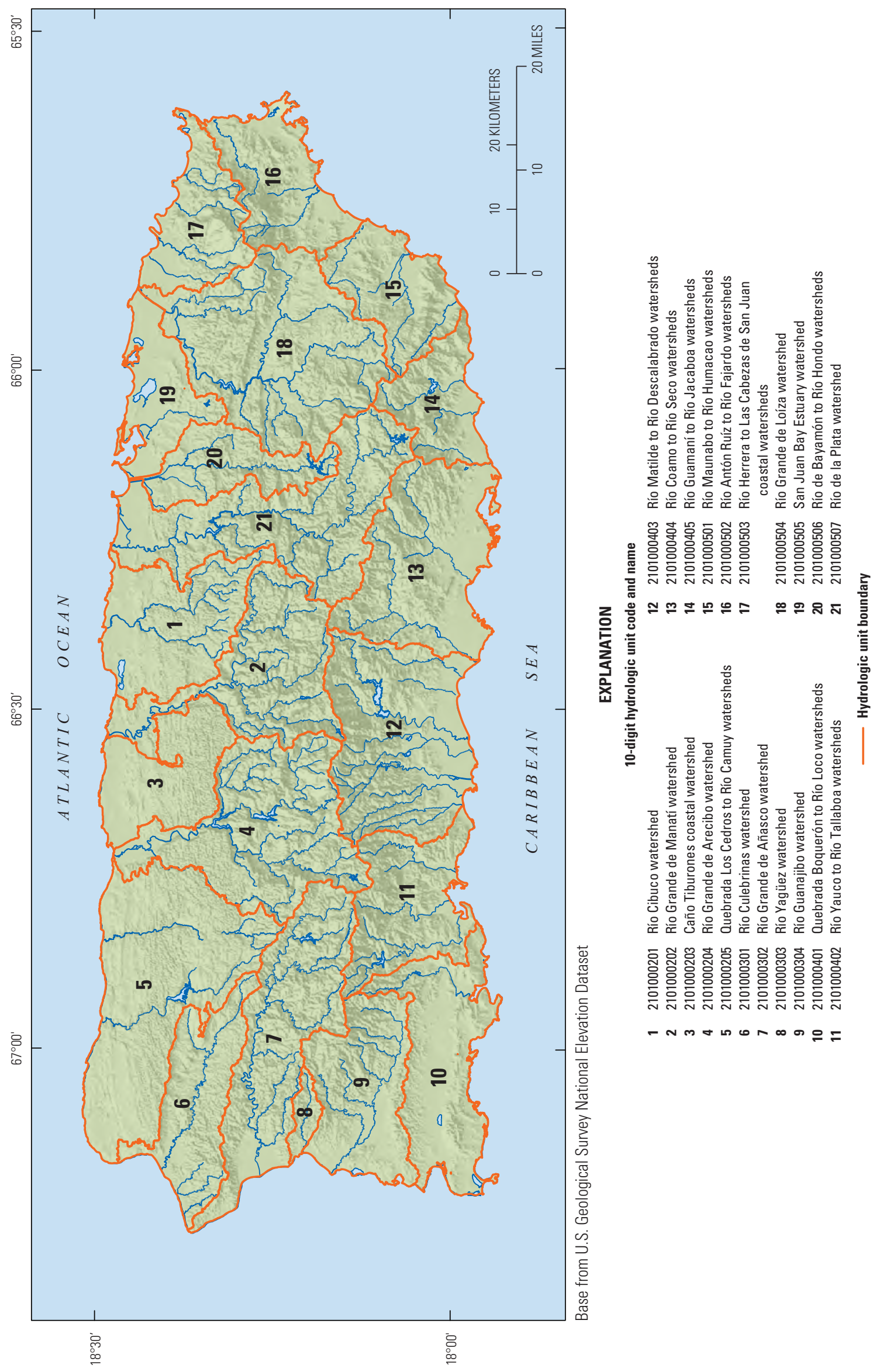

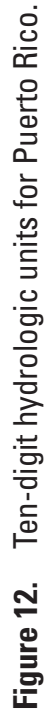


In Puerto Rico, the demand for water for a variety of purposes has resulted in the construction of diversion structures in about $2,600 \mathrm{~km}^{2}$ or nearly 60 percent of the total watershed area that is underlain by volcanic rocks. Use of these diversion structures has resulted in the complete capture of annual low flows in several small perennial streams and in the Río Grande de Loíza and the Río de la Plata, which are two of the largest watersheds on the island. The Río Grande de Loíza and the Río de la Plata watersheds (fig. 12) are the principal sources of public water supply for the San Juan metropolitan area. In 2005, the total streamflow diverted from these watersheds for public water supply was about 660,000 cubic meters per day $\left(\mathrm{m}^{3} / \mathrm{d}\right)$ or 7.6 cubic meters per second $\left(\mathrm{m}^{3} / \mathrm{s}\right)$ with about 40 percent diverted to filtration plants that serve a metropolitan population of about 1.4 million (Molina-Rivera and Gómez-Gómez, 2008).
The general water balance for the island of Puerto Rico and the amount of water available from surface-water and groundwater sources is graphically illustrated in figure 13 . In an average year, the island receives about $1,825 \mathrm{~mm}$ of rainfall, of which $1,189 \mathrm{~mm}$ or nearly 65 percent is lost to evapotranspiration. Of the total remaining available water, groundwater accounts for about $53 \mathrm{~mm}$ (or $14.6 \mathrm{~m}^{3} / \mathrm{s}$ ) and streamflow accounts for about $583 \mathrm{~mm}$ (or $161 \mathrm{~m}^{3} / \mathrm{s}$ ); about $76 \mathrm{~mm}\left(\right.$ or $21 \mathrm{~m}^{3} / \mathrm{s}$ ) of streamflow is available as baseflow to lowland areas. A common occurrence in streams on the island of Puerto Rico is the loss of an indeterminate amount of baseflow to coastal wetlands or aquifers during low-flow periods when sandbars seal river outlets preventing direct outflow to the sea. These low-flow periods include February and March for streams draining watersheds underlain by volcanic rocks, and July and August for streams receiving drainage from the North Coast Limestone belt.

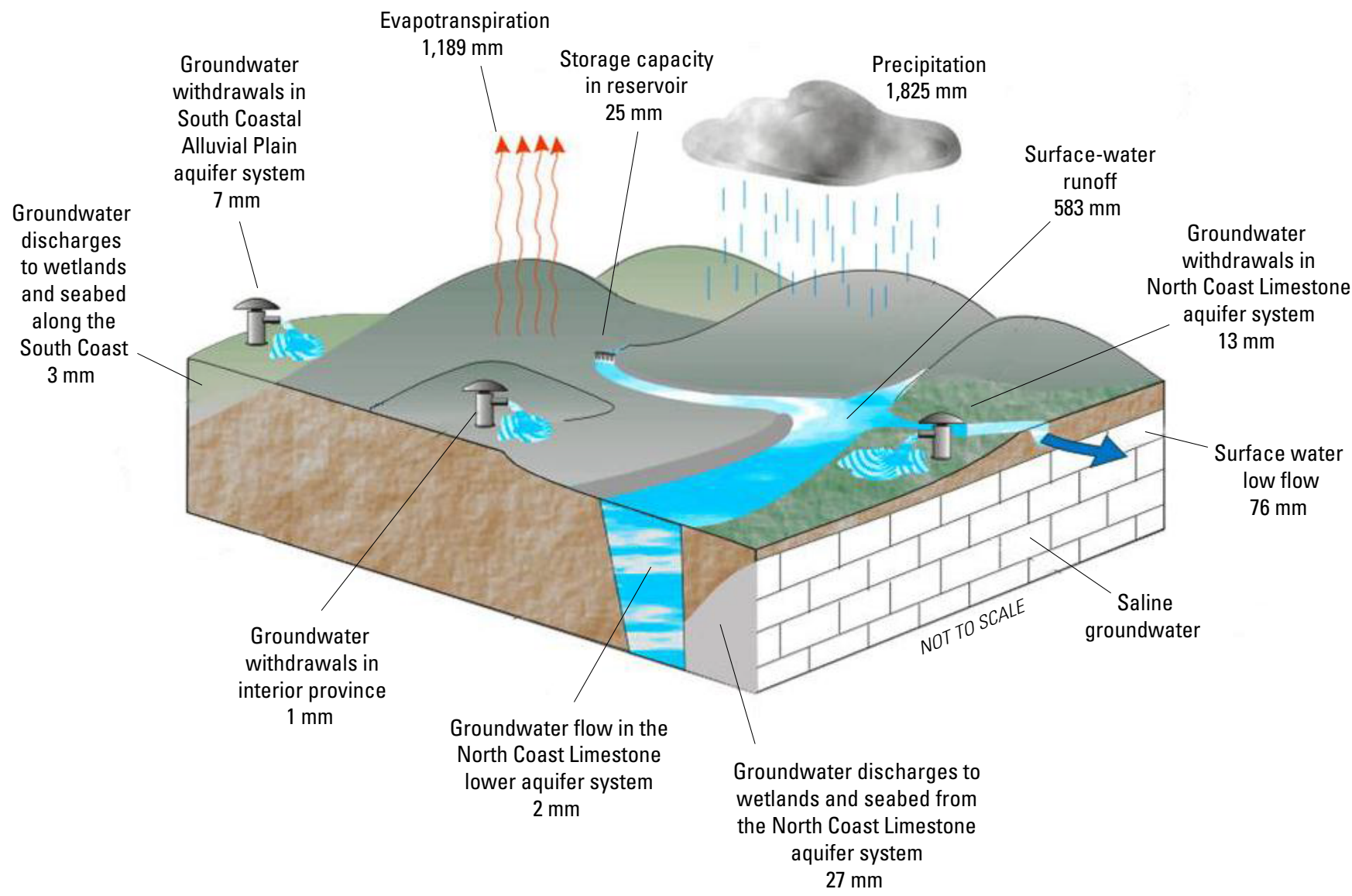

Figure 13. Generalized water balance for the island of Puerto Rico. 


\section{Contents of the Hydrogeologic Map}

The hydrogeologic map shows the location and spatial extent of the groundwater provinces on the main island of Puerto Rico and the outlying islands of Vieques, Culebra, and Mona. The most intensively developed and extensive of these provinces are the North Coast and the South Coast on the main island of Puerto Rico.

\section{Description of Aquifer Systems}

Puerto Rico is subdivided into six groundwater provinces on the main island and two additional provinces on the outlying islands of Vieques, Culebra, and Mona. These provinces have been primarily segregated on the basis of similar geologic units and physiographic features, following the classification of McGuinnes (1948). These provinces were originally published by Molina-Rivera and Gómez-Gómez (2008). As illustrated in figure 14, the eight groundwater provinces consist of the (1) North Coast Province, (2) South Coast Province, (3) West Coast Province, (4) East Coast Province, (5) Lajas Valley, (6) Interior Province, (7) Vieques and Culebra islands, and (8) Mona island.

\section{North Coast Province}

The North Coast Province covers about 2,100 $\mathrm{km}^{2}$ and is underlain by the North Coast Limestone aquifer system, which includes the most productive and extensive aquifers in Puerto Rico (fig. 14). Aquifers in the North Coast Province are formed by carbonates, predominantly limestone, and terrigenous clastic beds of Tertiary age that extend from the west coast to the San Juan metropolitan area. In the area extending from the Río Grande de Arecibo to the Río Espíritu Santo, which is east of San Juan, fine-grained coastal plain deposits overlie the limestone and terrigenous clastic beds and serve as a semiconfining unit.

Limestone and terrigenous clastic units in the North Coast Province show no evidence of faulting or deformation in the outcrop areas. The units dip northerly averaging about 5 degrees in outcrop areas and strike about 47 minutes east (Giusti and Bennet, 1976).

In the North Coast Province, rocks of middle Tertiary age, which constitute the main aquifers, have been subdivided in ascending order, from oldest to youngest, into the following stratigraphic units: San Sebastián Formation, Mucarabones Sand, Lares Limestone, Cibao Formation, Aguada Limestone (also known as Los Puertos), Aymamón Limestone, and the Camuy Formation (also known as the Quebradilla Limestone) (figs. 15, 16). The San Sebastián Formation is not considered to be a water-bearing unit. The formation overlies volcanic bedrock and primarily consists of clay with secondary amounts of sand and gravel and locally, sandy limestone (Monroe, 1980). Toward the eastern part of the North Coast Province, the San Sebastián Formation is absent, mostly replaced by the partially time-equivalent (partially of the same age) Mucarabones Sand.
Fresh groundwater in the North Coast Limestone aquifer system is found in two principal aquifers identified as the upper and lower aquifers. The upper aquifer is located within the Aymamón and Aguada Limestone units, and within alluvial stream valleys and coastal plain deposits. The lower aquifer is located within limestone members (bioherms) of the Cibao Formation, the Lares Limestone, and the Mucarabones Sand. The Montebello Limestone Member of the Cibao Formation is the most productive unit of the lower aquifer. Areally, the lower aquifer is a regionally important source of groundwater in the area between the Río Grande de Arecibo and the Río Grande de Manatí (fig. 17).

The hydrogeologic properties of the carbonate rocks differ substantially, owing to diverse depositional environments that result from processes including uplift and northward tilting of the island's platform, eustatic changes in sea level, the evolution of north-flowing streams during the deposition of limestone units, and the development of drainage features resulting from solutional and erosional processes. On the basis of the substantially different hydrogeologic properties that characterize the carbonate rocks underlying the North Coast Province, the region has been divided into three subareas: (1) West Coast to Río Grande de Arecibo area, (2) Río Grande de Arecibo to Río de la Plata area, and (3) Río de la Plata to Río Espíritu Santo area (Gómez-Gómez and Heisel, 1980; fig. 14). The following sections describe the hydrogeologic features of each subarea.

\section{West Coast to Río Grande de Arecibo Area}

The West Coast to Río Grande de Arecibo area is characterized by cliffs that rise $45 \mathrm{~m}$ above mean sea level along much of the coast. As a result, there is no coastal plain in this area. The water-table altitude ranges from mean sea level to as much as $275 \mathrm{~m}$ above mean sea level within the Lares Limestone at a distance of about $6 \mathrm{~km}$ from the shoreline. West of the Río Guajataca, the water-table altitude reaches a maximum of $150 \mathrm{~m}$ within the Cibao Formation; the level of the water table may be controlled by the water level in the Lago de Guajataca reservoir, which has a spillway altitude of $197 \mathrm{~m}$. Test drilling conducted during 1986 near Hatillo (site number NC-6, fig. 15) and during 1987 near Isabela (site number NC-11, fig. 15) penetrated permeable units of the Cibao Formation (and possibly the Lares Limestone) that contained fresh groundwater under confined conditions at depth near the coast.

Hydraulic characteristics of the aquifer system in this area are poorly known. Few existing wells tap the aquifer within the Aymamón and Aguada Limestones and have yields that range from 3 to 6 liters per second (L/s). Specific capacity generally is less than 0.2 liter per second per meter $(\mathrm{L} / \mathrm{s} / \mathrm{m})$ of drawdown. Data obtained during exploratory drilling during 1986 and 1987 near Hatillo and Isabela (sites NC-6 and NC-11, respectively, fig. 15) indicated that the aquifer had a maximum head of $45 \mathrm{~m}$ above mean sea level at site NC-6 (about $20 \mathrm{~m}$ below the land surface datum) and $18 \mathrm{~m}$ above mean sea level at site $\mathrm{NC}-11$ (about $70 \mathrm{~m}$ below the land surface datum). 

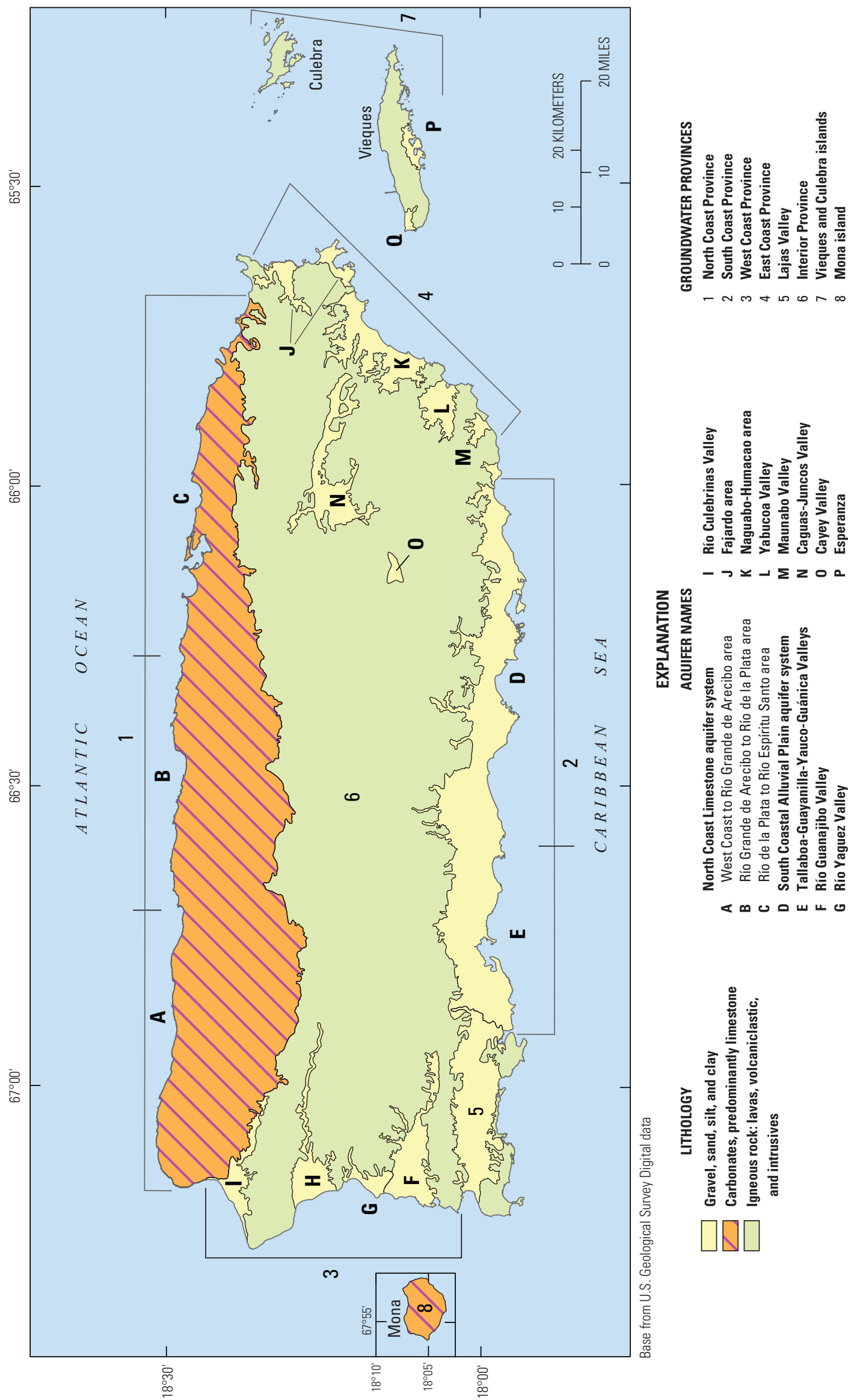

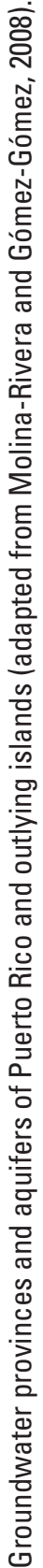




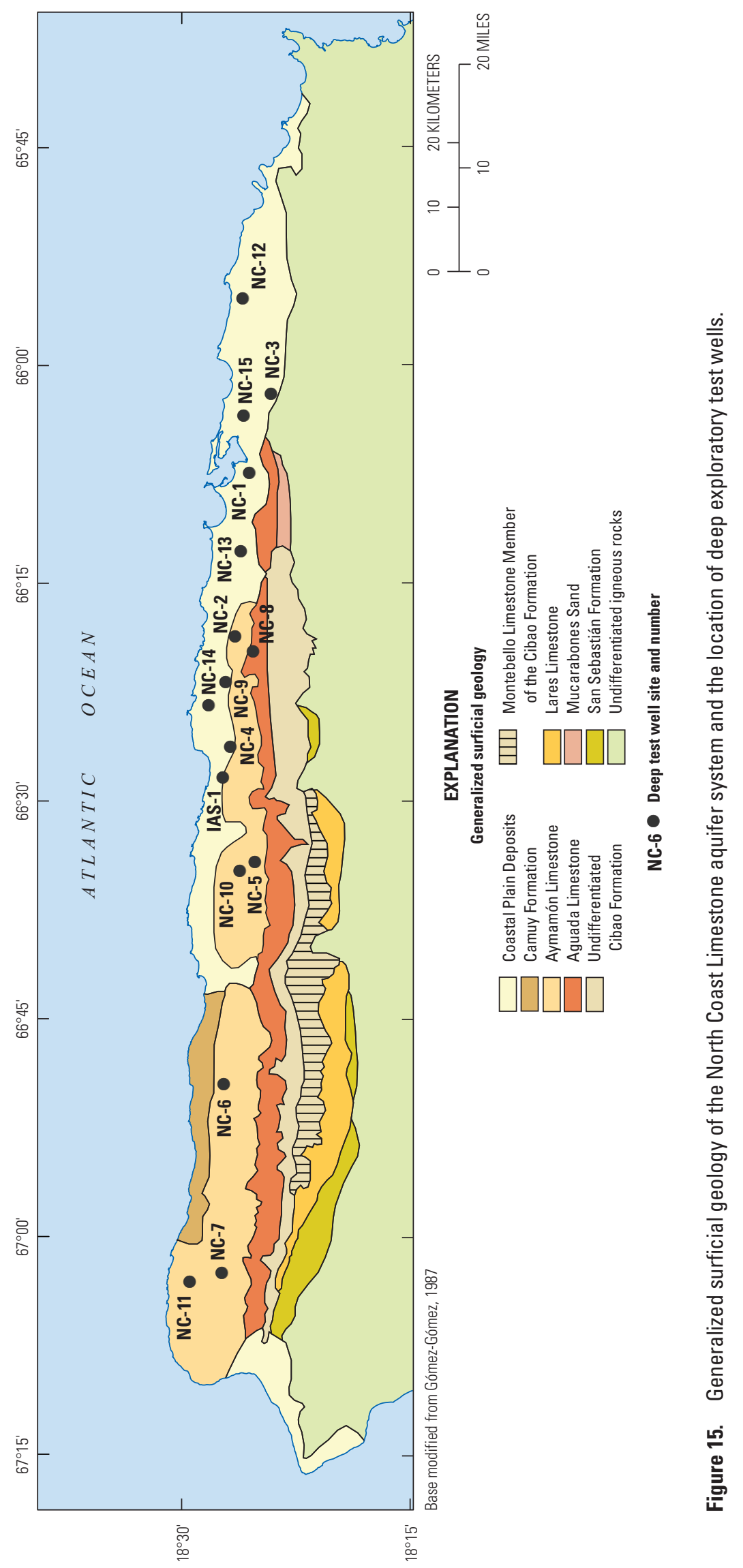




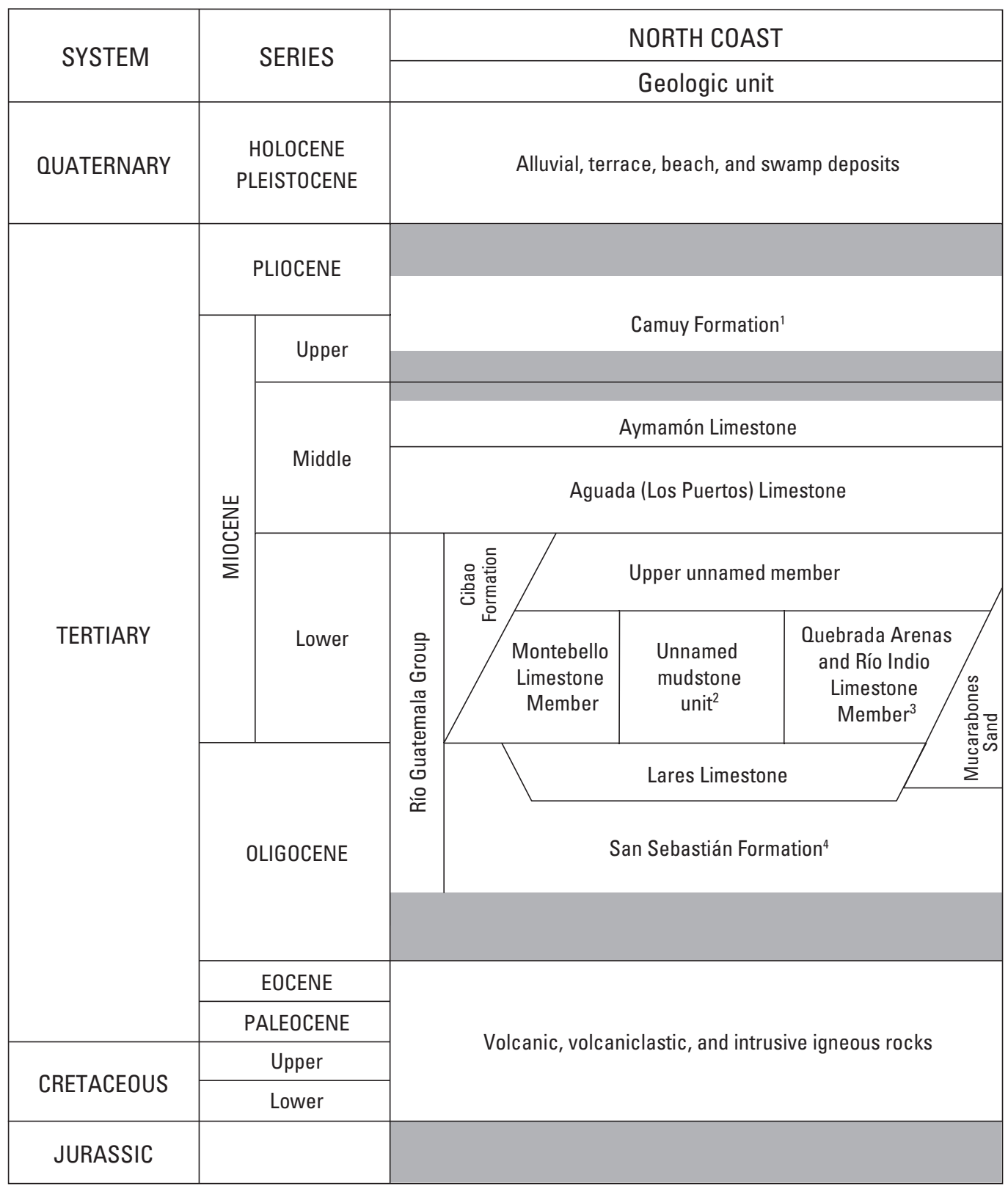

'Called the Quebradillas Limestone in some reports.

${ }^{2}$ Subsurface only.

${ }^{3}$ Both members may function as confining units in downdip areas.

${ }^{4}$ Contains local permeable beds in undip areas that may be hydraulically connected to the lower aquifer.

Figure 16. Stratigraphic chart showing varied nomenclature used for the same rocks in the North Coast Province (modified from Renken and others, 2002). 


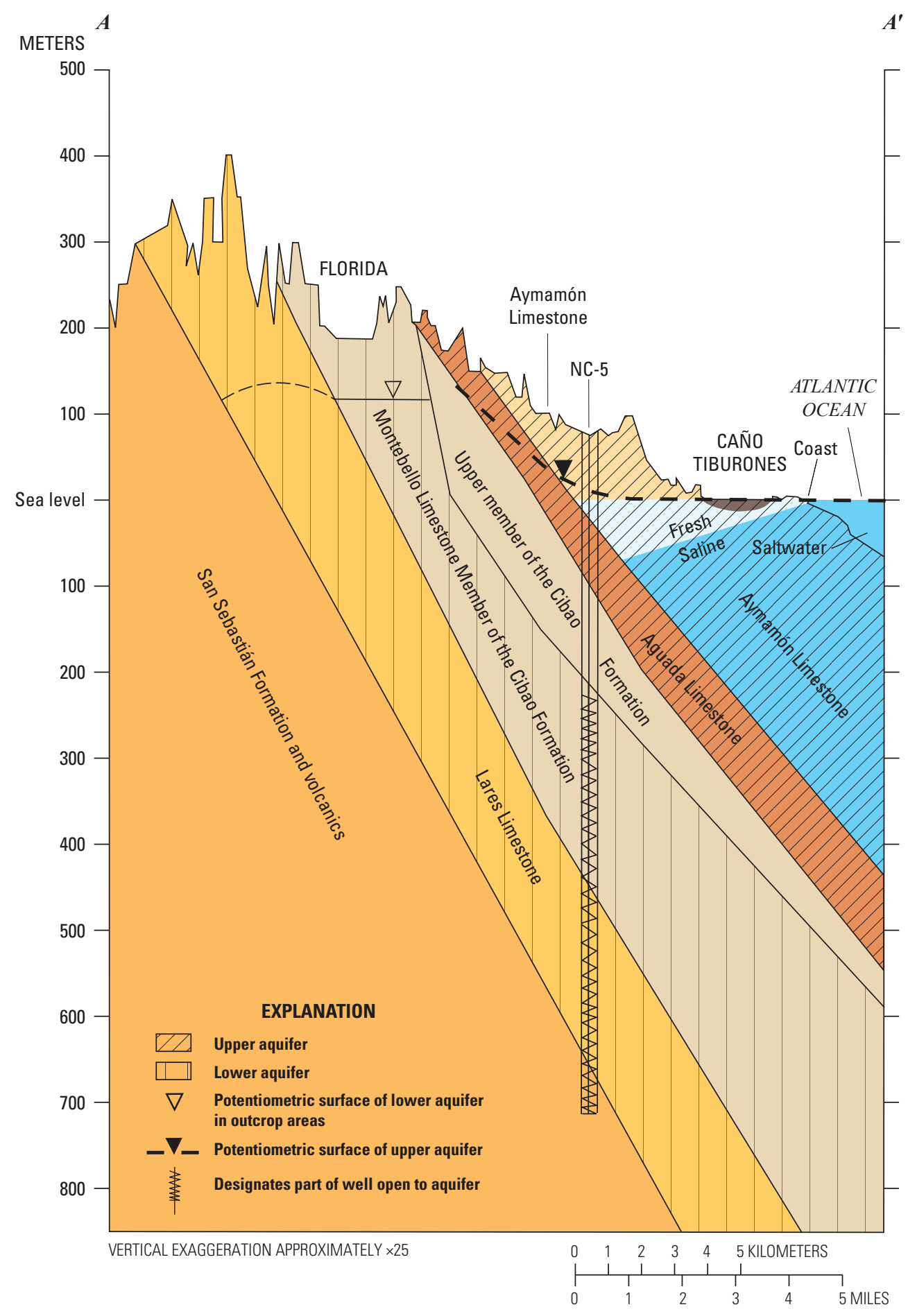

Figure 17. Generalized hydrogeologic cross section through the North Coast Limestone aquifer system between the Río Grande de Arecibo and the Río Grande de Manatí near Barceloneta (line of section along longitude 66 $6^{\circ} 7^{\prime} 39^{\prime \prime}$ shown in figure 10). 
Recharge to the aquifer occurs primarily from rainfall infiltrating throughout limestone outcrop areas and possibly as seepage from the Lago de Guajataca reservoir, which was constructed in 1928. Groundwater discharges to the coast and along the main rivers. Springflow along the south-facing escarpment, near the shoreline and along the main rivers, also may constitute substantial aquifer discharge features in this part of the North Coast Limestone aquifer system. Groundwater withdrawals in this area are estimated to be less than $20,000 \mathrm{~m}^{3} / \mathrm{d}$.

\section{Río Grande de Arecibo to Río de la Plata Area}

Groundwater in the $800-\mathrm{km}^{2}$ Río Grande de Arecibo to Río de la Plata area is unconfined in the Aymamón and Aguada Limestones, in alluvial valleys, and in areas where the Montebello Limestone Member of the Cibao Formation and the Lares Limestone crop out (fig. 17). In 1968, groundwater was found to be confined in wells drilled into the down-dip sections of the Montebello and Lares Limestones in the vicinity of Barceloneta. In the vicinity of Barceloneta, heads initially were as much as $150 \mathrm{~m}$ above mean sea level (or generally $60 \mathrm{~m}$ above the land surface datum). By 1990, 14 artesian water-supply wells had been drilled in the area between Barceloneta and Manatí.

The lateral extension of the lower artesian aquifer was defined during test drilling conducted between 1986 and 1988 . Hydraulically, the lower aquifer is the down-dip extension of the Montebello Limestone Member of the Cibao Formation and the regionally extensive Lares Limestone. Transmissivity of the lower aquifer near the coast is greatest in the Montebello Limestone Member; in the vicinity of Barceloneta, the transmissivity is estimated to range from 100 to 200 meters squared per day $\left(\mathrm{m}^{2} / \mathrm{d}\right)$ and decreases to less than $100 \mathrm{~m}^{2} / \mathrm{d}$ near the Río Grande de Arecibo. East of Río Grande de Manatí, the Montebello Limestone Member is replaced by a time-equivalent mudstone unit. Due to low transmissivities, the potential development of groundwater in the underlying Lares Limestone is limited. Although the Lares Limestone is laterally extensive, comprising the entire lower aquifer, transmissivity within outcrop areas is estimated to be less than $25 \mathrm{~m}^{2} / \mathrm{d}$. In areas near the coast where deep wells tap confined parts of the lower aquifer, transmissitivities are less than $45 \mathrm{~m}^{2} / \mathrm{d}$.

During 1986 and 1987, test wells tapping the lower aquifer were drilled in areas near the coast between the west end of Laguna Tortuguero (test well IAS-1, fig. 15) and the Río de la Plata (test well NC-13, fig. 15). Head measurements made in these wells indicated a general lowering of the potentiometric surface to the east (fig. 18). The configuration of the potentiometric surface indicates that along the downdip section east of the Río Grande de Manatí, the regional direction of groundwater flow in the lower aquifer is east with regional discharge occurring beneath the coastal plain east of the Río de la Plata. The eastern-most discharge area may be in the vicinity of the wetlands at Sabana Seca, which is located about $5 \mathrm{~km}$ east of the Río de la Plata.

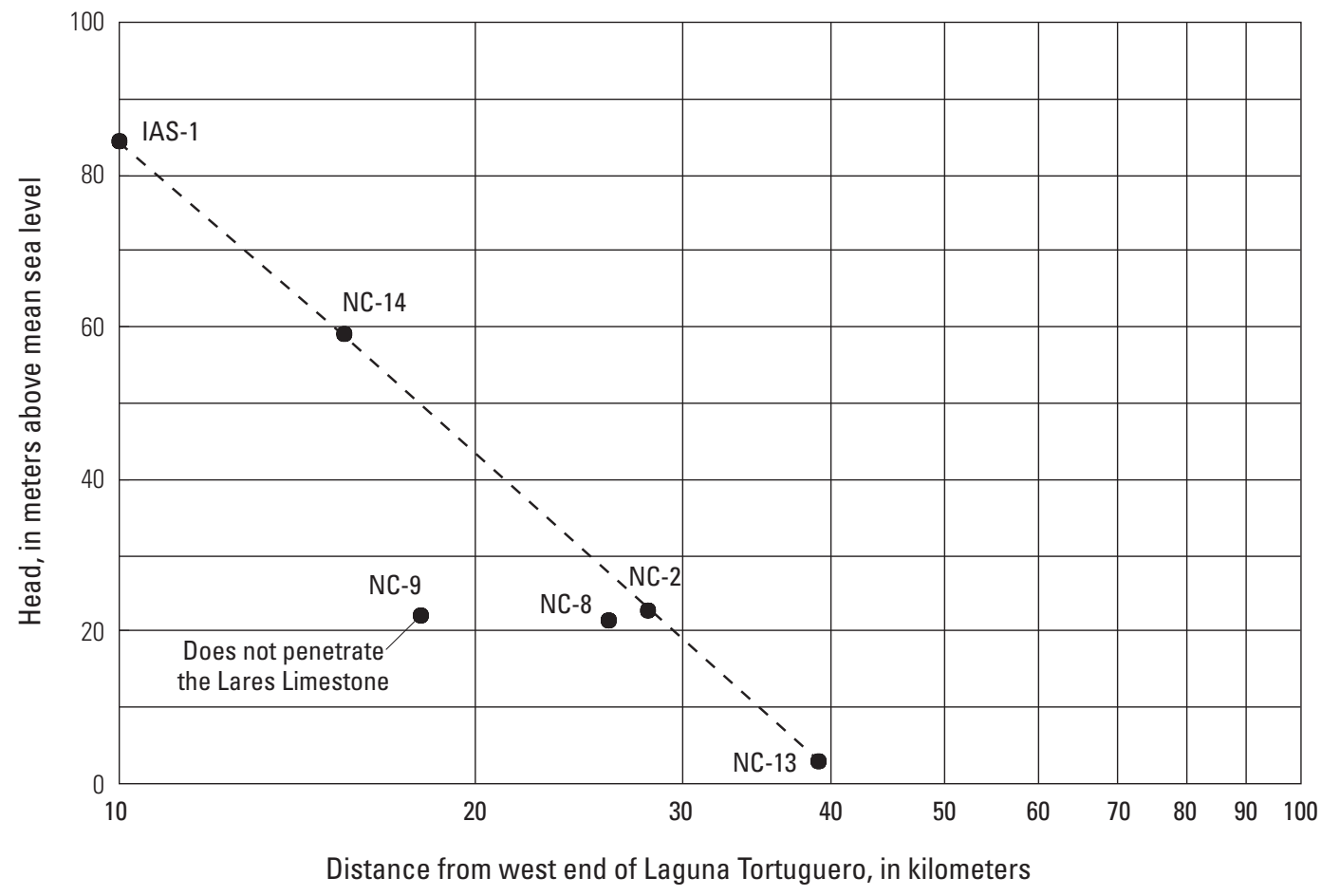

Figure 18. Initial heads in test wells penetrating the Lares Limestone in the North Coast Limestone lower aquifer. Variations of head with the logarithm of distance indicate possible aquifer discharge eastward to wetlands east of the town of Toa Baja (for actual distance subtract 10 from the indicated distance on the graph; test well locations shown in figure 15). 
The unconfined or upper aquifer, which is contained within the Aymamón and Aguada Limestones in the area between the Río Grande de Arecibo to Río de la Plata, is the most productive aquifer in the North Coast Province. The aquifer, however, exists mostly as a lens of freshwater overlying saltwater with the thickness of the freshwater lens controlled primarily by natural aquifer discharge features such as streams, wetlands, or springs, or locally, by artificial discharge features such as drainage works and water-supply wells. In general, the freshwater lens extends inland to about the 3-m potentiometric surface contour, which is located approximately along latitude $18^{\circ} 26^{\prime}$ or generally $5 \mathrm{~km}$ from the coastline. Inland from this latitude in the area between the Río Grande de Arecibo and the Río Cibuco, the upper part of the Cibao Formation forms the base of the upper aquifer and hydraulically separates the unconfined upper aquifer from the underlying confined lower aquifer.

East of the Río Cibuco and inland from about latitude $18^{\circ} 26^{\prime}$, the upper part of the Cibao Formation does not seem to fully confine the groundwater contained in the Cibao Formation and Lares Limestone. Transmissivity values for the freshwater part of the unconfined aquifer overlying saltwater near the coast typically range from 2,000 to $15,000 \mathrm{~m}^{2} / \mathrm{d}$ and decrease rapidly inland. In the part of the upper aquifer contained within the Aguada Limestone and bounded beneath by the Cibao Formation, the transmissivity commonly is less than $500 \mathrm{~m}^{2} / \mathrm{d}$. Farther inland where the groundwater in the Cibao Formation and Lares Limestone is unconfined, the transmissivity is less than $20 \mathrm{~m}^{2} / \mathrm{d}$; locally, the transmissivity could be zero in the chalk units of the Lares Limestone.

As in the western part of the North Coast Province, groundwater flow in this area has been modified substantially from predevelopment conditions. The most notable change has been the dewatering of coastal wetlands, particularly the Caño Tiburones in the area between the Río Grande de Arecibo and the Río Grande de Manatí, and the construction of a drainage channel that connects Laguna Tortuguero with the Atlantic Ocean (plate 1). At Caño Tiburones, water levels were lowered from about 1 to $2 \mathrm{~m}$ above mean sea level in 1930 to as much as $2 \mathrm{~m}$ below mean sea level in 1980 as a result of constructing extensive drainage canals, tidal gates, and a dewatering pumping station. In 1998, however, agricultural use was completely phased out and an area of about 2,800 ha was declared a natural preserve by the Puerto Rico Department of Natural and Environmental Resources (http://www.drna.gobierno.pr). At Laguna Tortuguero, the ocean outlet lowered the water level in this relatively freshwater lagoon (the dissolved solids concentration was $1,000$ milligrams per liter $(\mathrm{mg} / \mathrm{L})$ in 1988$)$ from about $1.5 \mathrm{~m}$ above mean sea level in 1940 (Bennet and Giusti, 1972) to about $0.75 \mathrm{~m}$ above mean sea level in 1975 (QuiñonesMarquez and Fusté, 1978). East of Laguna Tortuguero in the area between the Río Cibuco and the Río de la Plata, the potentiometric surface declined as much as $3 \mathrm{~m}$ within the coastal plain between 1946 and 1983 (Gómez-Gómez and Torres-Sierra, 1988).
Prior to 1930, the development of groundwater supplies was relatively minor. Total groundwater withdrawal within the area increased from about $38,000 \mathrm{~m}^{3} / \mathrm{d}$ in 1940 to about $280,000 \mathrm{~m}^{3} / \mathrm{d}$ in 1985 . After 1985 , withdrawals for publicsupply use began to decline and were substantially reduced after completion of the North Coast Superaqueduct in 2000, which made water available to the San Juan metropolitan area from the Río Grande de Arecibo Basin. In 2005, groundwater withdrawals were estimated at about $150,000 \mathrm{~m}^{3} / \mathrm{d}$ (Molina-Rivera and Gómez-Gómez, 2008). Of the total 1985 withdrawals, an estimated $10,000 \mathrm{~m}^{3} / \mathrm{d}$ were withdrawn for industrial uses from the lower aquifer by artesian wells located in the general vicinity of Barceloneta and Manatí. In the vicinity of Barceloneta, the head in the lower aquifer declined from $150 \mathrm{~m}$ above mean sea level in 1968 to $96 \mathrm{~m}$ above mean sea level in 1989 (fig. 19). Prior to 1985, heads measured in flowing artesian wells tapping the lower aquifer declined to near land surface as a result of groundwater withdrawals. By 1985, however, a reduction in withdrawals resulted in the stabilization of heads in the lower aquifer to about 1990 (fig. 19). Between 1990 and 2002, heads decreased and were near $65 \mathrm{~m}$ above mean sea level in 2002.

\section{Río de la Plata to Río Espíritu Santo Area}

In the Río de la Plata to Río Espíritu Santo area, fresh groundwater is unconfined within the undifferentiated coastal plain deposits and the alluvial deposits of the major streams and within the Aguada Limestone, the Cibao Formation, and the Mucarabones Sand. In the area between the Río de Bayamón and the Río Piedras, groundwater is confined in the basal part of the Cibao Formation or possibly the basal part of the Aguada Limestone and in the Mucarabones Sand (Anderson, 1976). In the area between the Río de Bayamón and the Río Piedras, fresh groundwater in the Aymamón and Aguada Limestones is limited primarily to the inland-most parts of the formations as a result of saltwater encroachment (fig. 20).

Alluvium, terrace deposits, blanket sand, beach, and dune deposits overlie the Aymamón and Aguada Limestones throughout most of the area. The thickness of these deposits ranges from a maximum of $100 \mathrm{~m}$ within major stream valleys to about $30 \mathrm{~m}$ or less elsewhere. Except for an increase in sand and clay in the eastern part of the formation, the Aguada Limestone is similar in lithology to other areas west of the Río de la Plata.

In the Río de la Plata to Río Bayamón area, the Cibao Formation consists of limestone, sand, and clay. West of the Río de Bayamón, the Cibao Formation intertongues and grades laterally eastward into the Mucarabones Sand. Similarly, the Aguada Limestone is intercalated with chalky beds of the Cibao Formation and becomes indistinguishable from the Cibao Formation about $0.5 \mathrm{~km}$ east of the Río de la Plata. The Mucarabones Sand consists of fine to medium sand. Near the base of the Mucarabones unit, the sand coarsens and the formation contains gravel and lenses of greenish-gray sandy clay. The Mucarabones Sand reaches a maximum thickness of $100 \mathrm{~m}$ in the area between the Río de la Plata and the Río de Bayamón. 


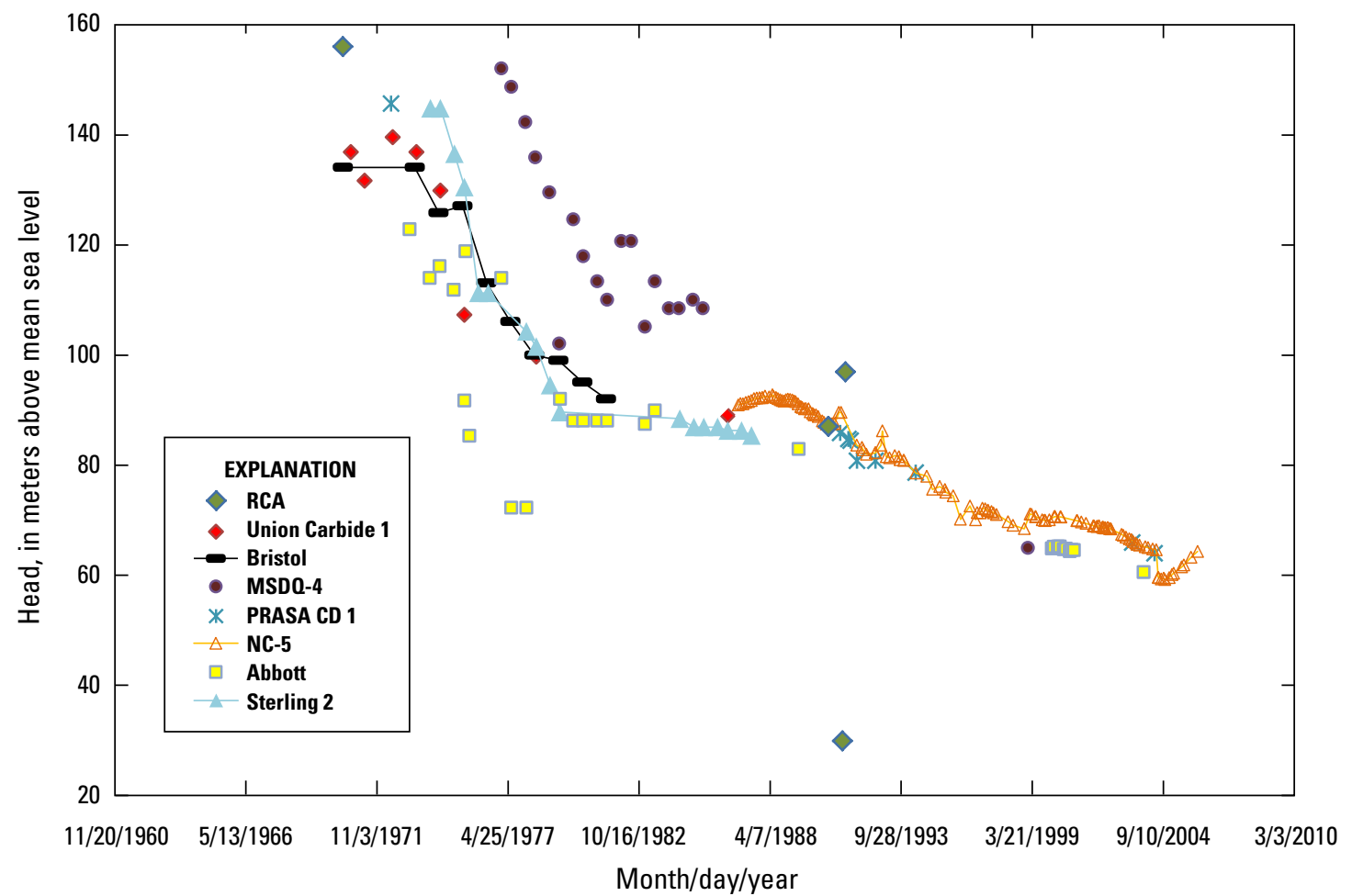

Figure 19. Head change at selected industrial and public-supply wells in the North Coast Limestone lower aquifer in the area of Barceloneta.

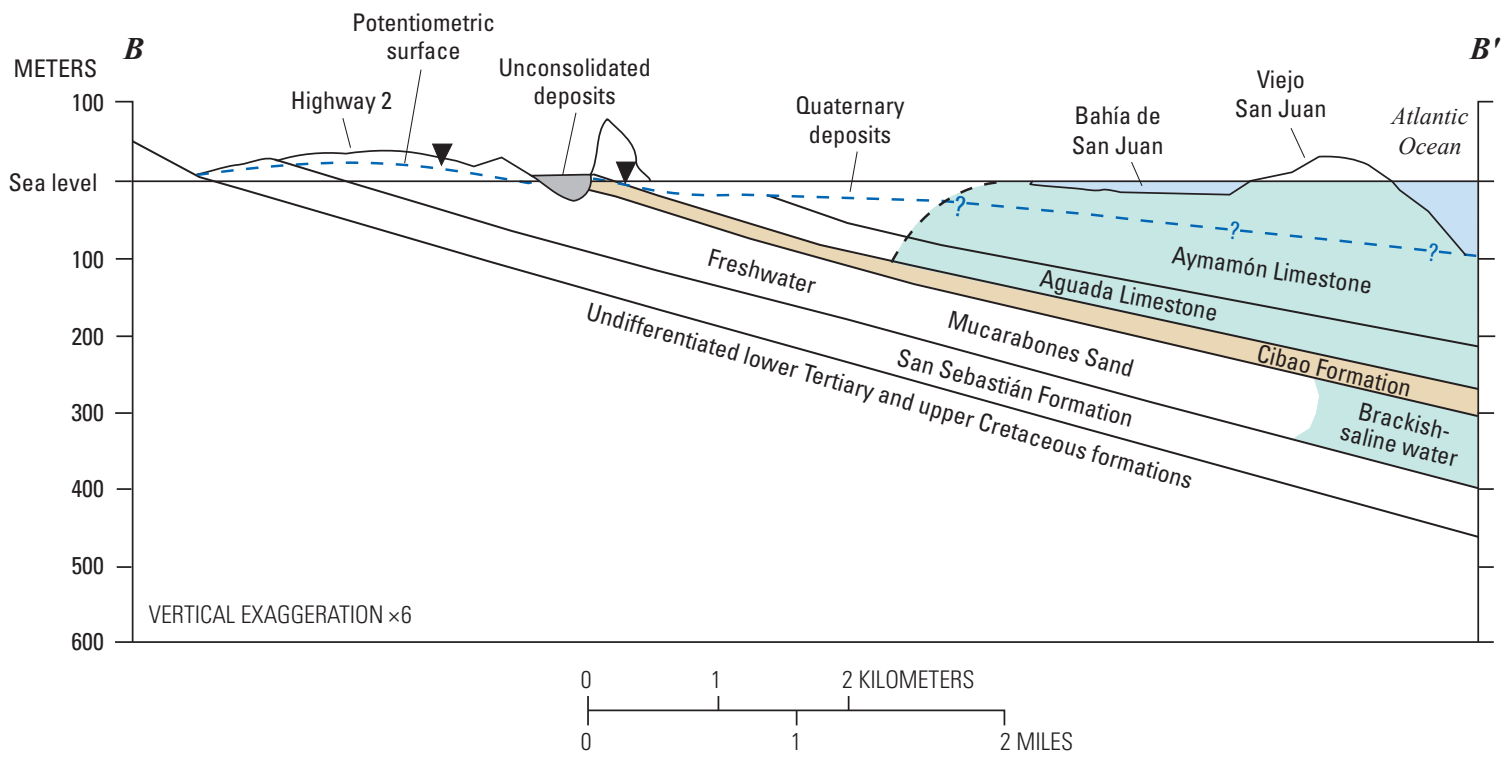

Figure 20. Generalized hydrogeologic cross section through the North Coast Limestone aquifer system in the San Juan area (line of section shown in figure 10). 
The Aguada Limestone is the principal source of freshwater between the Río de la Plata and Sabana Seca (plate 1). Transmissivities in this area range from 1,000 to $2,000 \mathrm{~m}^{2} / \mathrm{d}$. Eastward from Sabana Seca, both the Cibao Formation and the Mucarabones Sand are hydraulically interconnected near their outcrop areas. Aquifer tests conducted in wells tapping both the Cibao and the Mucarabones units indicate the estimated transmissivity to be less than $1,000 \mathrm{~m}^{2} / \mathrm{d}$. Few wells exclusively tap the Mucarabones Sand; therefore, the potential of this unit as a water-supply source in down-dip areas is unknown. The surficial coastal plain deposits essentially are the only source of freshwater in areas east of the Río Grande de Loíza. Groundwater within the coastal plain deposits exists as a freshwater lens or lenses overlying saltwater. The thickness of the freshwater lenses is not more than $30 \mathrm{~m}$, which limits groundwater development for domestic uses and supplies for watering livestock (Torres-González, 1984).

The groundwater resources of the Río de la Plata to the Río Espíritu Santo area were among the first to be developed or affected by dewatering works along the north coast. The use of groundwater in the area is minimal because of widespread saltwater intrusion. Most well fields have been abandoned or destroyed except in the western part of the area between the Río de la Plata and Sabana Seca, where saltwater intrusion has been limited by reducing groundwater withdrawals. Overall groundwater withdrawals in the Río de la Plata to the Río Espíritu Santo area are estimated to be less than $5,000 \mathrm{~m}^{3} / \mathrm{d}$.

\section{South Coast Province}

The South Coast Province covers about $800 \mathrm{~km}^{2}$ along the southern coast of Puerto Rico. Aquifers in this region are composed of coalescing alluvial fans and terrace deposits that form a continuous coastal plain in the area from Ponce to Patillas, and limestones of Tertiary age that underlie alluvial stream valleys in the area extending from the Río Tallaboa to the Río Loco (fig. 14). West of the Río Loco, the occurrence of groundwater is limited to alluvial deposits of ephemeral streams.

On the basis of physiographic differences, the South Coast Province has been subdivided into two subareas: (1) the Patillas to Ponce area and (2) the Tallaboa-Guayanilla-Yauco-Guánica Valleys (Gómez-Gómez and Heisel, 1980). The following sections describe the hydrogeologic features of each subarea.

\section{Patillas to Ponce Area}

The Patillas to Ponce area of the South Coast Province is about $65 \mathrm{~km}$ long and averages about $5 \mathrm{~km}$ wide. The Patillas to Ponce area is underlain by the South Coastal Alluvial Plain aquifer system, which is the second most extensive aquifer in Puerto Rico (fig. 21). The coastal plain deposits that compose the aquifer system consist of a series of alluvial fans formed by sediment-laden, fast-flowing intermittent streams that originate at altitudes above $300 \mathrm{~m}$ and within $25 \mathrm{~km}$ of the Caribbean Sea. Below an altitude of about 45 to $30 \mathrm{~m}$, coastal plain sediments are Holocene and Pleistocene (?) in age. Delta-fan deposits in this area contain a high proportion of sand and gravel at the apex of the major fans, becoming finer grained toward the coast and in interfluvial areas.

Coastal plain sediments are underlain by volcanic rocks in the area east of Río Coamo and by sedimentary rocks of middle Tertiary age throughout most of the coastal plain west of Río Coamo (plate 1). The volcanic rocks consist of massive to thick-bedded andesite tuff and welded tuff, porphyritic basalt, volcanic breccia, sandstone, and siltstone. Rocks of middle Tertiary age consist of the Juana Díaz Formation, which is overlain by the Ponce Limestone. The Juana Díaz Formation has been informally subdivided into a mudstone, a basal conglomerate, chalk beds, and upper clastic beds. The Ponce Limestone is largely a recrystallized limestone locally rich in reefal material that is relatively high in calcium carbonate. Where saturated, the Juana Díaz Formation contains saline groundwater (dissolved solids concentration greater than $1,000 \mathrm{mg} / \mathrm{L}$ ). Also, because of its highly clayey nature and consequently low permeability, the Juana Díaz Formation is not considered to be an aquifer. In the vicinity of the Ponce urban area, the alluvium is underlain by the Ponce Limestone, which seems to have karstic features. These features are inferred by the specific capacity of wells that typically are less than $6 \mathrm{~L} / \mathrm{s} / \mathrm{m}$, tapping alluvium exclusively, and as high as $32 \mathrm{~L} / \mathrm{s} / \mathrm{m}$, tapping both alluvium and limestone.

Groundwater is unconfined within the alluvium, except along the coast where surficial deposits consisting of silt, clay, and swamp deposits serve as a semiconfining unit that hydraulically separates the surficial deposits from the underlying coarser more permeable alluvium. Throughout the coastal plain, the thickness of the alluvium differs substantially as a result of faulting and weathering of the bedrock units. In the area between Río Grande de Patillas and Río Jueyes, the depth to bedrock along the coast ranges from $128 \mathrm{~m}$ at Río Nigua fan to $36 \mathrm{~m}$ near the mouth of Río Seco (fig. 21). In the area between Río Jueyes and the western limit of the coastal plain at Ponce, the thickness of the alluvium is about $915 \mathrm{~m}$ near the mouth of Río Coamo (test well site CPR-1, fig. 21) and about 120 m near the mouth of Río Cañas (test well site CPR-2, fig. 21). In the area west of Río Jacaguas, groundwater is present in both the alluvium and associated clastic deposits and in the underlying limestone (plate 1). Test drilling conducted near Ponce in 1987 confirmed the occurrence of groundwater in the underlying limestone at a depth of $180 \mathrm{~m}$ below mean sea level (test well SC-7, figs. 21, 22; however, the dissolved solids concentration of groundwater increased with depth to $1,500 \mathrm{mg} / \mathrm{L}$.

Transmissivity of the South Coastal Alluvial Plain aquifer system varies substantially between the alluvial fans and within each fan. The highest transmissivities were found within Río Nigua de Salinas (Río Salinas) and Río Coamo fans. Transmissivity is estimated to be as high as $6,500 \mathrm{~m}^{2} / \mathrm{d}$ within the apex of each alluvial fan. East of Río Nigua fan, aquifer transmissivity is substantially lower, with values commonly less than $500 \mathrm{~m}^{2} / \mathrm{d}$, except within Río Nigua fan at Arroyo where the transmissivity can be as much as $2,000 \mathrm{~m}^{2} / \mathrm{d}$. 


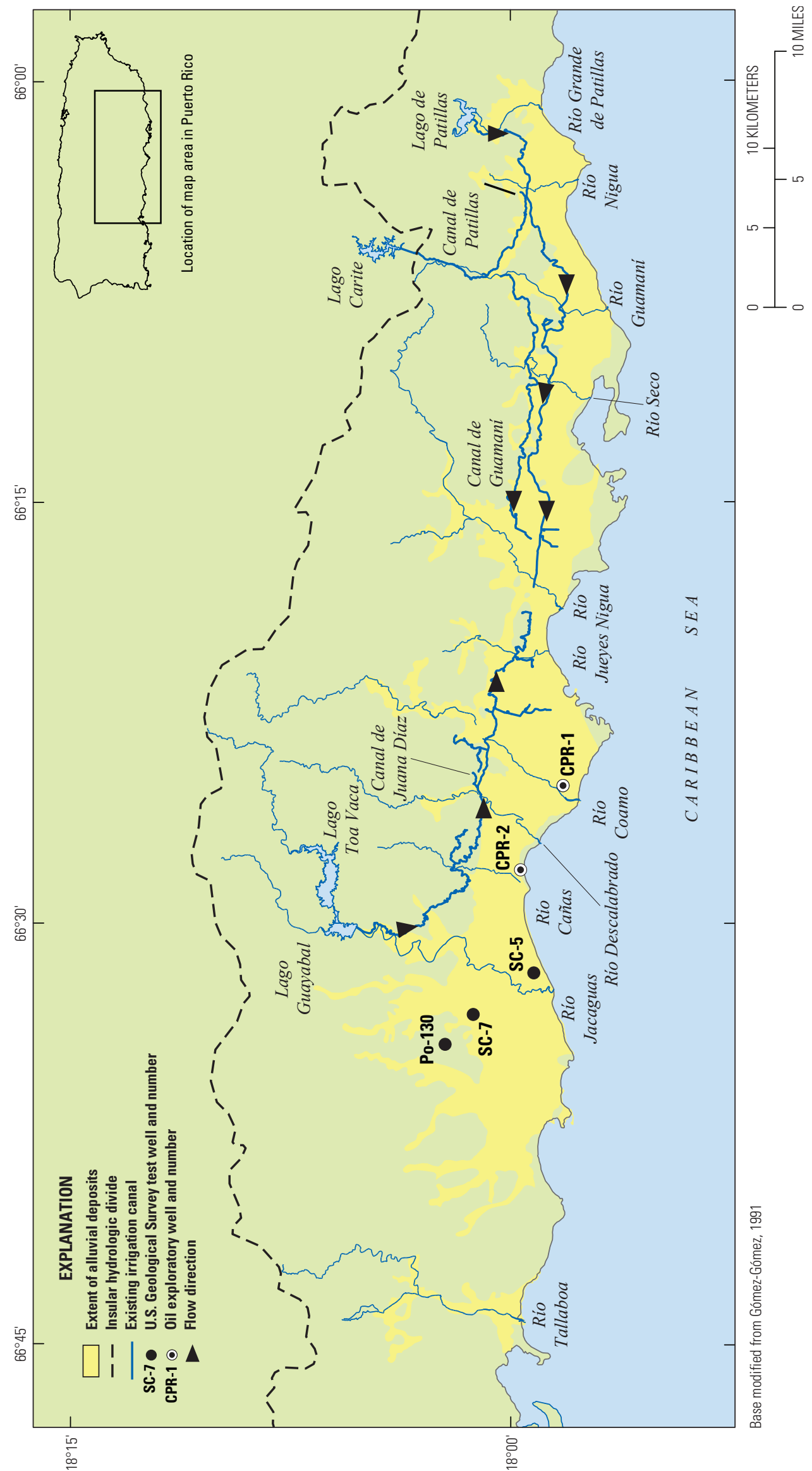

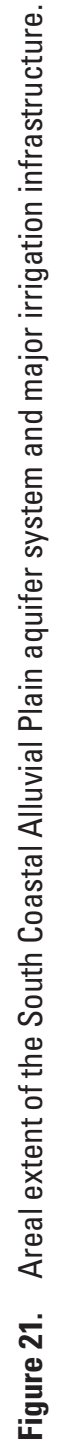


West of Río Descalabrado and east of Río Jacaguas, aquifer transmissivity is about $500 \mathrm{~m}^{2} / \mathrm{d}$. In the area west of Río Jacaguas, large spatial variations in transmissivity exist; values of $500 \mathrm{~m}^{2} / \mathrm{d}$ are common, with values increasing to as much as $6,500 \mathrm{~m}^{2} / \mathrm{d}$ in areas underlain by karstified limestone within the municipality of Ponce.

In the Patillas to Ponce area, prior to construction of the first irrigation canals and diversions in the late 1800 s, the source of recharge to the aquifer was from streamflow seepage and from rainfall infiltration through the alluvial and terrace deposits. Discharge from the aquifer occurred as flow to near shore and offshore springs, as seepage to the seabed and lower portions of stream channels, and as evapotranspiration from the shallow water table near the coast. Prior to the beginning of the 1900s, an extensive network of irrigation canals and reservoirs already existed in the area between Río Jacaguas and Ponce. Additionally, small-scale irrigation works existed in Río Coamo and Río Nigua fans and in the vicinity of Guayama and were limited to diversion of baseflows from streams near the foothills. The first large-scale surface-water irrigation system was completed in 1914 and consisted of the Canal de Patillas and Lago de Patillas reservoir; Lago Carite reservoir north of the insular hydrologic divide in the Río de la Plata watershed and a diversion tunnel to Río Guamaní; the Canal de Juana Díaz, Lago Guayabal, and Lago Coamo reservoirs. Originally, the combined flows through these canals averaged about $285,000 \mathrm{~m}^{3} / \mathrm{d}$. With the completion of Lago Guineo and Lago Matrullas reservoirs north of the insular hydrologic divide in the Río Grande de Manatí watershed and the completion of the diversion tunnel to Río Jacaguas in 1935, however, the system of reservoirs, tunnels, pump stations, and canals conveyed as much as $300,000 \mathrm{~m}^{3} / \mathrm{d}$.

Large-scale groundwater development of the South Coastal Alluvial Plain aquifer system commenced in 1910 with the construction of steam-operated pumps that were powered by kerosene. By 1925, about 50 of these pumping installations existed, most with capacities above $60 \mathrm{~L} / \mathrm{s}$ and groundwater withdrawals totaling about $80,000 \mathrm{~m}^{3} / \mathrm{d}$. The greatest expansion in construction of irrigation water-supply wells occurred during the 1930s when electricity was extended into the area, bagasse-fueled steam generators were installed at sugar mills, and deep turbine pumps were introduced. In addition, water works to supply irrigation needs and largescale dewatering operations were implemented during the late 1930s to control the spread of malaria and to reclaim additional land for sugarcane cultivation.

A review of well construction logs indicates that between 1930 and 1987 the potentiometric surface along the coastal artesian zone declined by as much as $1.5 \mathrm{~m}$ in the Ponce area and by as much as $3.0 \mathrm{~m}$ at Santa Isabel. In the Río Nigua fan and toward the eastern part of the coastal plain, groundwater levels had not changed substantially between 1920 and 1986. In general, aquifer recharge has been augmented by the irrigation-canal network with discharge occurring mainly through groundwater withdrawals and by drainage ditches. In 1980 , irrigation deliveries were approximately $240,000 \mathrm{~m}^{3} / \mathrm{d}$ by means of the government-operated irrigation-canal network located east of Río Jacaguas. West of Río Jacaguas, a privately operated irrigation-canal network may have conveyed an additional $40,000 \mathrm{~m}^{3} / \mathrm{d}$. Net groundwater withdrawals (consumptive use) during 1980 averaged about 190,000 $\mathrm{m}^{3} / \mathrm{d}$. Of this amount, about 40 percent was used for public water supply with the remainder designated for irrigation. By 2005, net groundwater withdrawals were estimated at about $170,000 \mathrm{~m}^{3} / \mathrm{d}$, of which about 60 percent was for public supply, 35 percent for irrigation, and 2 percent for industrial use (industrial and thermoelectric) (Molina-Rivera and Gómez-Gómez, 2008).

\section{Tallaboa-Guayanilla-Yauco-Guánica Valleys}

The main aquifers in the Tallaboa-Guayanilla-YaucoGuánica valleys are formed by the alluvium deposited within the stream valleys. The alluvium consists of coarse sand and gravel that grade seaward to fine sand, silt, clay, and swamp deposits. Bedrock underlying these valleys consists of the Juana Díaz Formation in inland areas and the Ponce Limestone near the coast under conditions similar to those found in the Río Tallaboa valley (fig. 23). Although groundwater is present in outcrop areas, the bedrock generally is not considered to be an aquifer because of the low yield to wells and high concentration of dissolved solids from wells tapping the limestone bedrock exclusively; within outcrop areas, the dissolved solids concentration is about $2,000 \mathrm{mg} / \mathrm{L}$. The valley alluvium is underlain by the Ponce Limestone, which has developed secondary porosity and is tapped by wells also open to the alluvium.

Groundwater in the Tallaboa-Guayanilla-Yauco-Guánica valleys is unconfined and occurs within the alluvial deposits and the Ponce Limestone. Near the coast, groundwater is present as a freshwater lens overlying saltwater. The saturated thickness of the freshwater lens throughout the lower parts of the valleys is unknown. Recharge to these aquifers is derived primarily from streamflow as seepage through the streambed or by spatial infiltration of streamflow diversions for irrigation where such practices occur. In all stream valleys except the Río Guayanilla valley, streamflow is derived in large part from reservoirs located north of the insular hydrologic divide (plate 1). Discharge occurs through groundwater withdrawals at wells, through seepage to streams in the lower parts of the valleys, by evapotranspiration within the near-shore part of the aquifer where the water table is near land surface, and to a lesser extent as seepage to the seabed. The hydrologic system in these valleys has been modified such that the relative importance of any aquifer recharge or discharge process could vary substantially from year to year. For example, gross groundwater withdrawals were estimated at about $150,000 \mathrm{~m}^{3} / \mathrm{d}$ in the early 1970 s; however, by 1985 , withdrawals had diminished to about $75,000 \mathrm{~m}^{3} / \mathrm{d}$ as a result of the complete shutdown of the petrochemical complex in the Tallaboa and Guayanilla valleys and the closure of the island's largest sugarcane mill at Guánica. By 2005, groundwater withdrawals were estimated at $55,000 \mathrm{~m}^{3} / \mathrm{d}$, of which 57 percent was for public supply, 38 percent for irrigation, 1 percent for domestic use, and the remaining 4 percent mostly for thermoelectric power production (Molina-Rivera and Gómez-Gómez, 2008). 


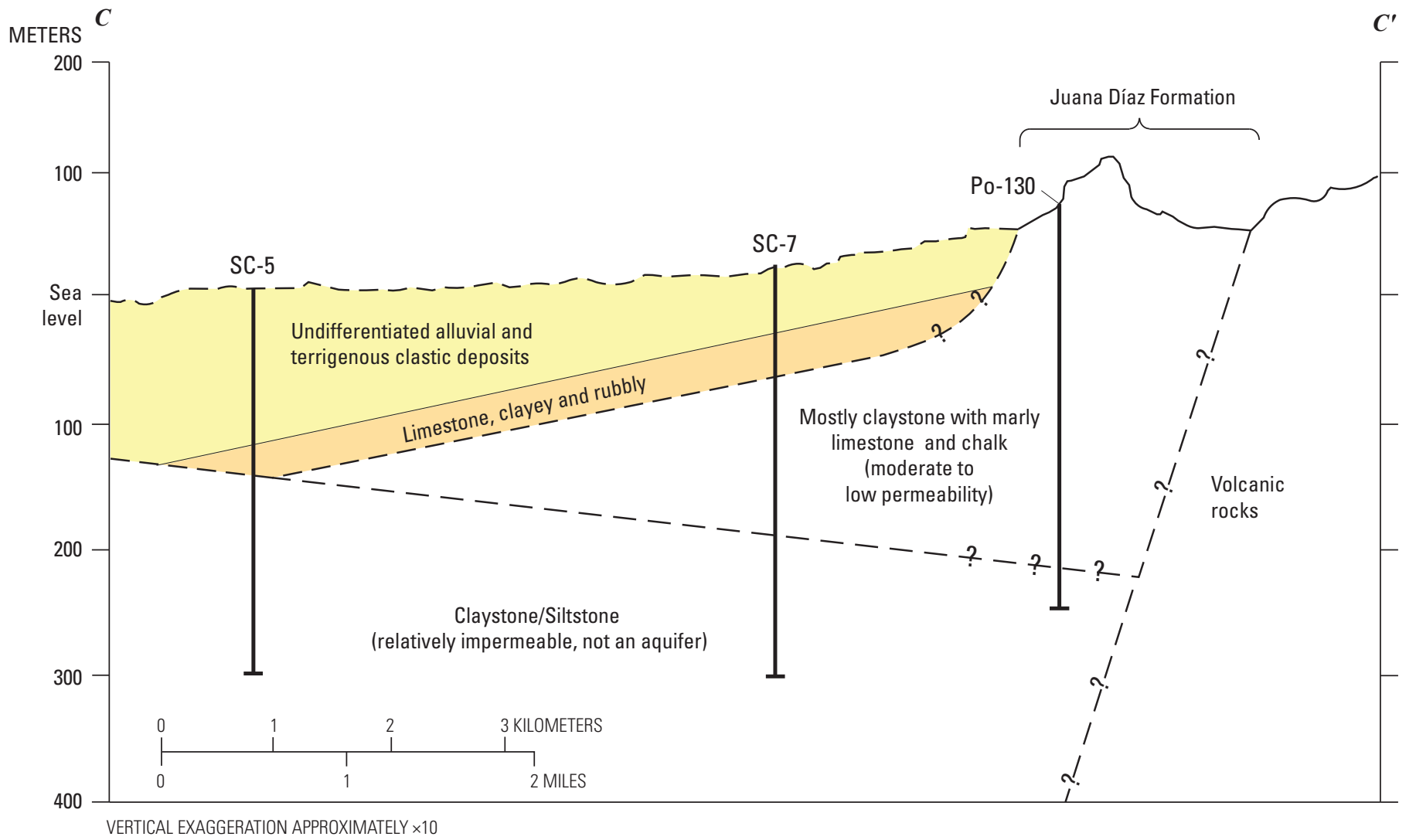

Figure 22. Generalized hydrogeologic cross section through the South Coastal Alluvial Plain aquifer system near Ponce (line of section shown in figure 10; location of Po-130, SC-7, and SC-5 shown in figure 21).

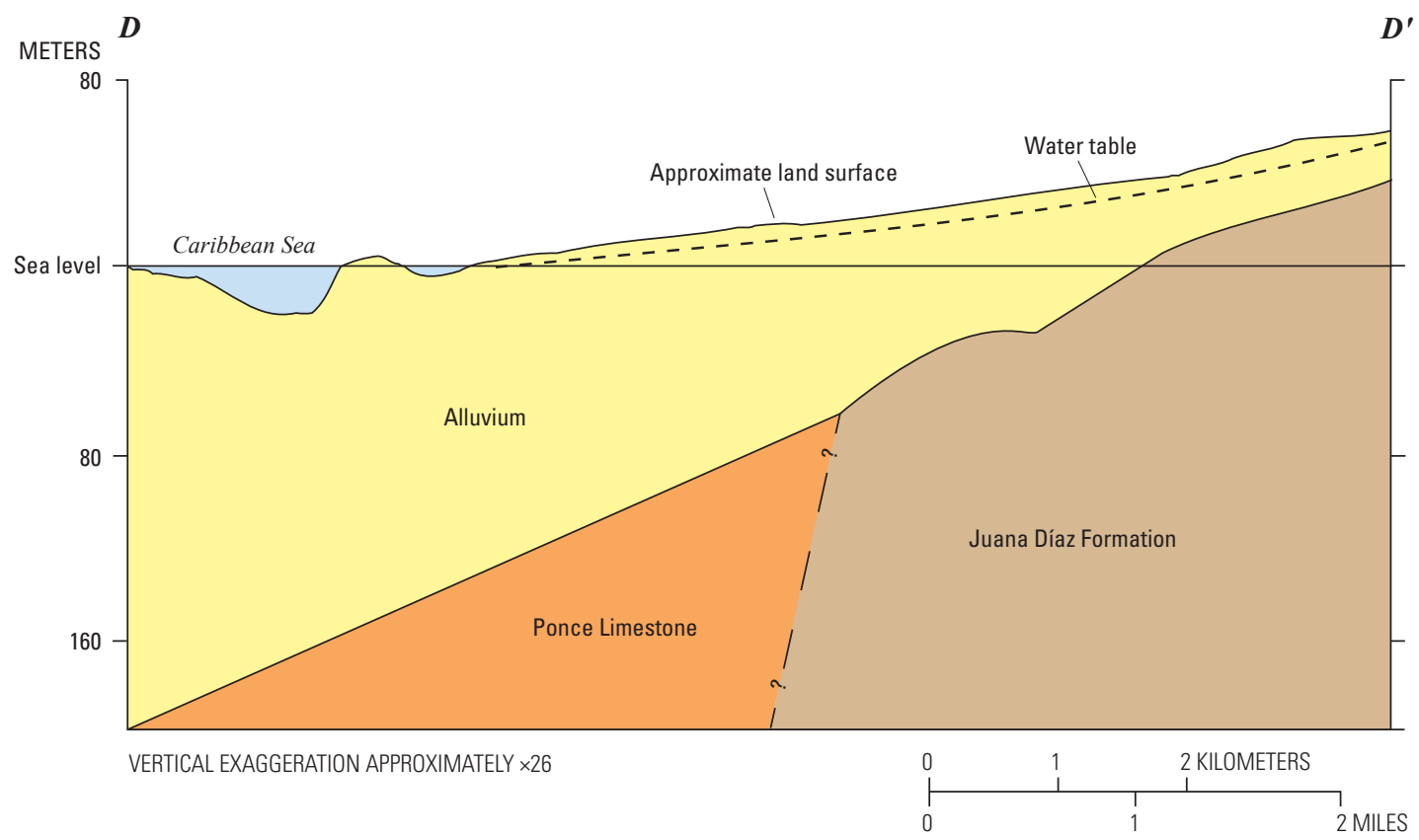

Figure 23. Generalized hydrogeologic cross section through the Río Tallaboa alluvial valley aquifer west of Ponce (line of section shown in figure 10). 


\section{West Coast Province}

Four alluvial valleys form the principal aquifers of the West Coast Province (fig. 14): Río Guanajibo $\left(130 \mathrm{~km}^{2}\right)$, Río Yaguez $\left(4 \mathrm{~km}^{2}\right)$, Río Grande de Añasco $\left(47 \mathrm{~km}^{2}\right)$, and Río Culebrinas $\left(25 \mathrm{~km}^{2}\right)$ valleys. The following sections describe the hydrogeologic features of each valley area within the province.

\section{Río Guanajibo}

The Río Guanajibo valley aquifer is formed by detrital clay, silt, sand, and gravel underlain by one or more beds of limestone (the limestone subsurface facies have not been correlated to outcrop facies, fig. 24). Alluvial sediments and other surficial deposits are as much as $30 \mathrm{~m}$ thick in the valley. Although the thickness of the limestone beds is unknown, it is estimated to be greater than $45 \mathrm{~m}$. The underlying bedrock consists of volcanic and sedimentary rocks of Cretaceous age; the rocks are predominantly basaltic andesite and mudstone as indicated by information obtained from wells drilled into the bedrock (ColónDieppa and Quiñones-Marquez, 1985). In the southwestern part of the valley near Cabo Rojo where wells tap both alluvium and limestone and have yields of $25 \mathrm{~L} / \mathrm{s}$, aquifer transmissivity is about $245 \mathrm{~m}^{2} / \mathrm{d}$. The higher transmissivity in this part of the valley is attributed to the underlying limestone units.

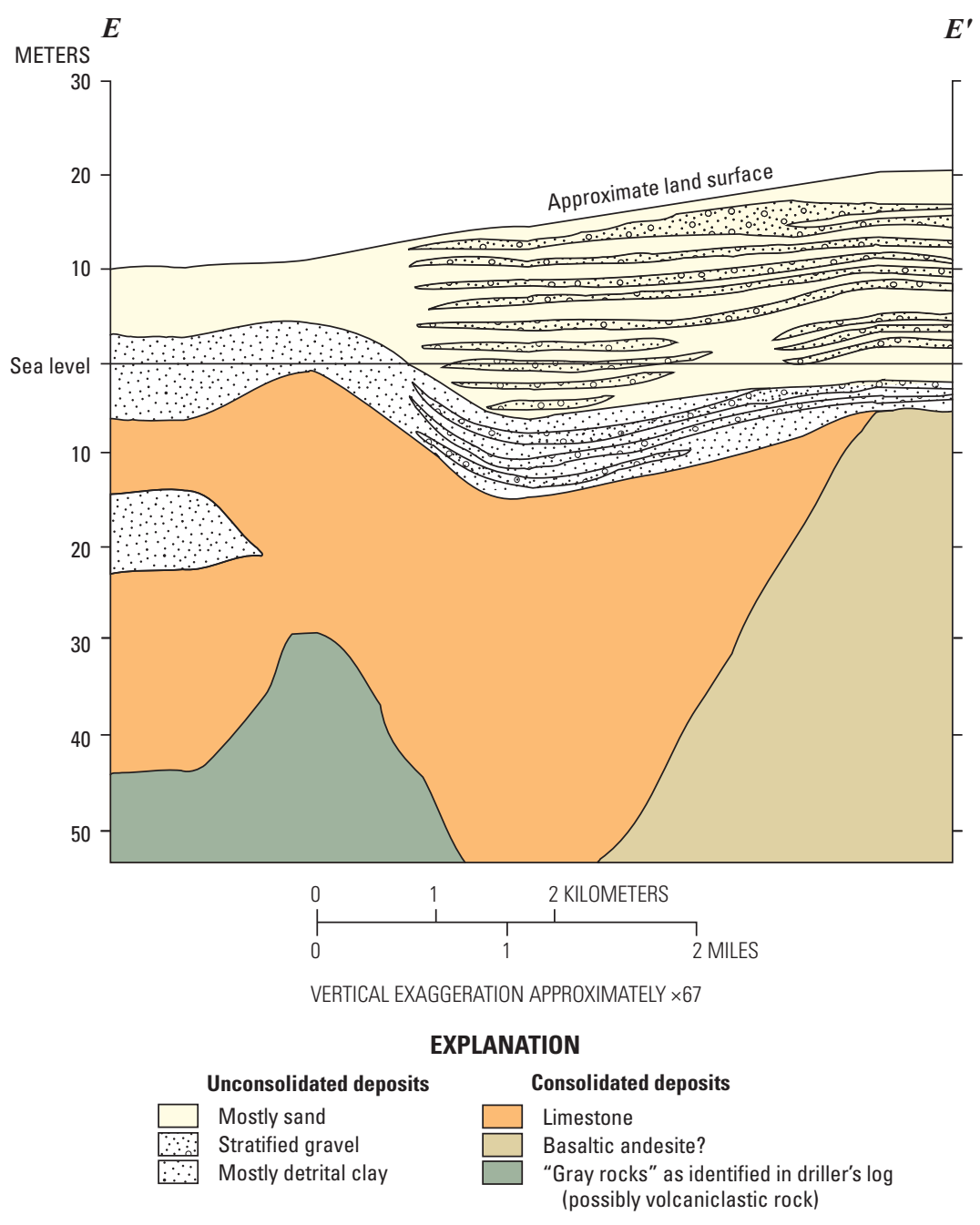

Figure 24. Generalized hydrogeologic cross section through the lower Río Guanajibo alluvial valley aquifer near Cabo Rojo (line of section shown in figure 10; modified from Colón-Dieppa and Quiñones-Marquez, 1985). 


\section{Río Yaguez}

In the Río Yaguez valley, the alluvium has a maximum known thickness of $60 \mathrm{~m}$ and is the principal aquifer (Bogart and others, 1964). The alluvial deposits are underlain by alternating layers of clastic sediments and limestone. In an area where a 30-m-deep well tapped the alluvium, the estimated transmissivity was $90 \mathrm{~m}^{2} / \mathrm{d}$.

\section{Río Grande de Añasco}

In the Río Grande de Añasco valley, the alluvium is as much as $138 \mathrm{~m}$ thick and predominately consists of clay strata interbedded with sand and one or more beds of limestone that have a thickness of about $14 \mathrm{~m}$. The few existing wells in the valley are insufficient to determine whether the limestone beds are laterally extensive or are discontinuous, isolated lenses. In an area where an 82-m-deep well tapped unconsolidated sediments and limestone, the estimated transmissivity was $85 \mathrm{~m}^{2} / \mathrm{d}$.

\section{Río Culebrinas}

No hydrogeologic information is available for the Río Culebrinas valley.

Groundwater flows in these stream-valley aquifers under predevelopment conditions should be similar to the flows in the Río Grande de Añasco alluvial valley (Díaz and Jordan, 1987). Recharge occurs primarily from rainfall infiltration, and discharge occurs as seepage to the streams and the seabed and as evapotranspiration. The latter may be the principal groundwater discharge mechanism in all valleys owing to the shallow water table. Extensive drainage ditches have been constructed in the Río Guanajibo, Río Grande de Añasco, and Río Culebrinas valleys to control waterlogging of soils; however, because of the high rainfall during most of the year, the water table remains near land surface. In the Río Yaguez valley, urbanization has covered nearly the entire area and use of the alluvial aquifer has essentially been abandoned. The only area where groundwater withdrawal is substantial is in the Río Guanajibo valley. Withdrawals in the Río Guanajibo valley primarily are for public supply and were estimated to be 20,000 $\mathrm{m}^{3} / \mathrm{d}$ in 1980 and about 21,500 m³ $/ \mathrm{d}$ in 2005 (MolinaRivera and Gómez-Gómez, 2008).

\section{East Coast Province}

The East Coast Province consists of the coastal area extending east of the Río Grande on the northeast side of the island to the Río Maunabo valley in the southeastern part of Puerto Rico (fig. 14). The province is subdivided into four major aquifer areas, which are identified as follows: (1) the Fajardo area covering about $33 \mathrm{~km}^{2}$, (2) the NaguaboHumacao area covering about $114 \mathrm{~km}^{2}$, (3) the Yabucoa valley covering about $50 \mathrm{~km}^{2}$, and (4) the Maunabo valley covering about $16 \mathrm{~km}^{2}$. The following sections describe the hydrogeologic features of the four major aquifer areas.

\section{Fajardo Area}

The Fajardo area extends from Punta Picúa on the north coast to Punta Lima on the east coast and is characterized by a narrow coastal plain and small alluvial stream valleys (plate 1). The alluvium, which forms the principal aquifer, consists of lenticular beds of clay, sand, and gravel, and weathered rock fragments at depths of less than $30 \mathrm{~m}$. The highest wateryielding units are in the lower alluvial fan of the Río Fajardo where inflow to the aquifer from the river may be induced through gravel and sand deposits. Groundwater withdrawal was at one time greatest at the town of Fajardo; however, saltwater encroachment from the sea resulted in the abandonment of large production wells by the early 1960s. In the Fajardo area, transmissivity of the alluvial aquifer is largely unknown, but may be about $100 \mathrm{~m}^{2} / \mathrm{d}$ in lower parts of the valleys where the total thickness of the alluvium is greatest.

\section{Naguabo-Humacao Area}

Aquifers in the Naguabo-Humacao area are formed by the coalescing alluvial fans of the Río Santiago, Río Blanco, Río Antón Ruiz, Río Humacao, and Río Candelero (plate 1). Generally, the alluvium in this area consists of fine sand, silt, clay, and swamp deposits that have a total saturated thickness of less than $20 \mathrm{~m}$ in inland areas unaffected by saltwater encroachment and as much as $50 \mathrm{~m}$ near the coast. Estimates of aquifer transmissivities range from 55 to $185 \mathrm{~m}^{2} / \mathrm{d}$ (Graves, 1989). In the Río Antón Ruiz alluvial valley where a test well was drilled into the alluvium, an estimated transmissivity of $140 \mathrm{~m}^{2} / \mathrm{d}$ was reported for a thickness of only $6 \mathrm{~m}$. This estimate indicates that transmissivities in the Río Antón Ruiz alluvial deposits may be the highest in the entire NaguaboHumacao area. Transmissivities in the Río Antón Ruiz alluvial deposits may be as great as $1,000 \mathrm{~m}^{2} / \mathrm{d}$ on the basis of data obtained from an abandoned irrigation well located in the upper valley, which penetrated the alluvium to a depth of $50 \mathrm{~m}$ and yielded $32 \mathrm{~L} / \mathrm{s}$.

\section{Yabucoa Valley}

The Yabucoa valley area is characterized by the Río Guayanés valley that has incised down through the San Lorenzo batholith, which is a granodiorite intrusion (plate 1). The bedrock surface is irregular and lies within $50 \mathrm{~m}$ of land surface along most of the coast. The bedrock is overlain by alluvium, which forms the principal aquifer in this area. The alluvium largely consists of clay with appreciable amounts of sand. The thickness of the alluvial deposits is as much as $90 \mathrm{~m}$ in the central part of the valley, but averages $30 \mathrm{~m}$ in most areas (Robison and Anders, 1973). Estimates of aquifer transmissivity range from 185 to $465 \mathrm{~m}^{2} / \mathrm{d}$ in areas where the saturated thickness of the alluvium varies between 40 and $50 \mathrm{~m}$ (Robison and Anders, 1973). 


\section{Maunabo Valley}

The principal aquifer in the Maunabo valley area is formed by alluvium that is up to $60 \mathrm{~m}$ thick. The alluvium consists of discontinuous, lenticular deposits of sand, gravel, and cobbles; however, drilling logs indicate that the lithology varies widely within the valley with some lenses containing coarser material than others. In general, lenses with coarser material are within the main axis of the valley along the Río Maunabo. Locally, aquifer transmissivity is as high as $325 \mathrm{~m}^{2} / \mathrm{d}$ in areas where the saturated thickness of the alluvium is $30 \mathrm{~m}$ (Adolphson and others, 1977).

Generally, groundwater in the alluvial aquifers within the East Coast Province is unconfined. In the Naguabo-Humacao area, semiconfined conditions were found in the vicinity of the foothills where wells were drilled into the weathered rock zone underlying the alluvium (Graves, 1989). Similar conditions were found in the Yabucoa valley; however, the semiconfining conditions were attributed to anisotropy caused by stratification of the alluvial deposits. An analog model constructed for the aquifer system in the Yabucoa valley indicated that the stratified conditions of the unconsolidated sediments induced a lateral to vertical hydraulic conductivity ratio of about 1,600 to 1 (Robison and Anders, 1973). Such conditions are important in assessing groundwater/surfacewater relations and in properly defining potential groundwater development without inducing saltwater encroachment.

Discharge from aquifers in the East Coast Province has been modified substantially by groundwater withdrawals and by dewatering wetland areas. In the Fajardo area, discharge to lower segments of streams occurs as evapotranspiration near the coast where the water table is shallow and as subsurface seepage near the shore. In the Naguabo-Humacao area, groundwater generally discharges to coastal swamps. In the Yabucoa area, discharge occurs primarily as evapotranspiration (Robison and Anders, 1973). In the Maunabo area, most groundwater discharges to the Río Maunabo constituting nearly 50 percent of the annual streamflow (Adolphson and others, 1977).

Groundwater withdrawals from aquifers in the East Coast Province are estimated at about $22,000 \mathrm{~m}^{3} / \mathrm{d}$. The greatest volume of groundwater is withdrawn in the Yabucoa valley area where the estimated pumpage is $13,000 \mathrm{~m}^{3} / \mathrm{d}$. Groundwater withdrawals in the other areas are estimated to be about $6,000 \mathrm{~m}^{3} / \mathrm{d}$ in the Maunabo valley area, $1,800 \mathrm{~m}^{3} / \mathrm{d}$ in the Naguabo-Humacao area, and less than $40 \mathrm{~m}^{3} / \mathrm{d}$ in the Fajardo area (Molina-Rivera and Gómez-Gómez, 2008).

\section{Lajas Valley}

Lajas Valley in southwestern Puerto Rico covers about $130 \mathrm{~km}^{2}$ and is bounded by ridges to the north and south (fig. 25). Topographically, the valley is bisected by a north-south trending drainage divide that parallels longitude $67^{\circ} 04^{\prime} 00^{\prime \prime}$ and reaches a maximum altitude of $14 \mathrm{~m}$. The valley floor slopes away from the divide to the east and west.

The valley is underlain by unconsolidated deposits of silt and clay that interfinger with coarse materials washed into the valley by ephemeral streams. The thickness of these deposits is as much as $90 \mathrm{~m}$. The unconsolidated deposits are underlain by one or more limestone units of undetermined thickness and age. In highland areas, several limestone units have been identified including the Ponce Limestone of Miocene age and the Cotui Limestone, the Parguera Limestone, and the Melones Limestone all of Late Cretaceous age (Volkman, 1984).

Several aquifers are located in the Lajas Valley. The most extensive aquifer is a leaky confined aquifer that is present within the limestone units underlying the unconsolidated deposits (plate 1). Recharge to this aquifer occurs as rainfall that infiltrates through the coarse alluvium found along the edges of the valley; as runoff from ephemeral streams especially along the more humid north side of the valley; and since 1955, as seepage of surface water diverted into the valley from the extensive hydroelectric power/irrigation infrastructure, which conveys water from the Río Grande de Añasco Basin across the insular hydrologic divide and south to Lago Lucchetti and Lago Loco reservoirs.

The potentiometric surface of the leaky confined aquifer has a maximum altitude of about $4 \mathrm{~m}$ near the topographic divide of the valley floor. Discharge from the aquifer toward the west occurs as subsurface flow to coastal wetlands and the seabed and as evapotranspiration. Discharge from the aquifer to the east occurs as seepage to the Cienaga el Anegado, which is a marsh, and the Laguna de Guánica, which has been an ephemeral brackish-water lagoon since the mid-1950s when the lagoon was drained. These wetland areas were dewatered in the 1950s by construction of tile underdrains and drainage canals with discharge directed to the Bahía de Guánica.

Transmissivity estimates for the limestone aquifer range from 200 to 3,000 $\mathrm{m}^{2} / \mathrm{d}$ (Anderson, 1977). The lowest transmissivity occurs in the area near the town of Lajas, and the highest values are measured in areas near the center of Lajas Valley. In the 1940s, groundwater withdrawals in Lajas Valley for irrigation purposes were estimated at $30,000 \mathrm{~m}^{3} / \mathrm{d}$. Withdrawals for irrigation were halted prior to 1955 due to salinization problems at wells. As a result, groundwater was replaced with surface water obtained from basins north of the insular hydrologic divide and delivered to farm lands through the Lajas Valley irrigation-canal network.

Surface-water deliveries to the valley averaged about $65,000 \mathrm{~m}^{3} / \mathrm{d}$ until 1980 when much of the farm land that had been cultivated previously in sugarcane was abandoned. In 1982, surface-water deliveries averaged only $22,000 \mathrm{~m}^{3} / \mathrm{d}$. Since about 1990, groundwater withdrawals have been limited to small-yield domestic wells tapping the alluvium along the valley edges and several wells tapping limestone units along the northeast slopes. Yields from these wells range from 10 to $15 \mathrm{~L} / \mathrm{s}$. The dissolved solids concentration in groundwater within the limestone units generally is $4,000 \mathrm{mg} / \mathrm{L}$, which makes the water unacceptable for most uses. Wells drilled into the limestone outcrop area in the northern part of the valley yield water with a dissolved solids concentration of about $600 \mathrm{mg} / \mathrm{L}$. Wells tapping alluvial deposits along the valley edges generally yield water with a dissolved solids concentration of about $1,000 \mathrm{mg} / \mathrm{L}$. 


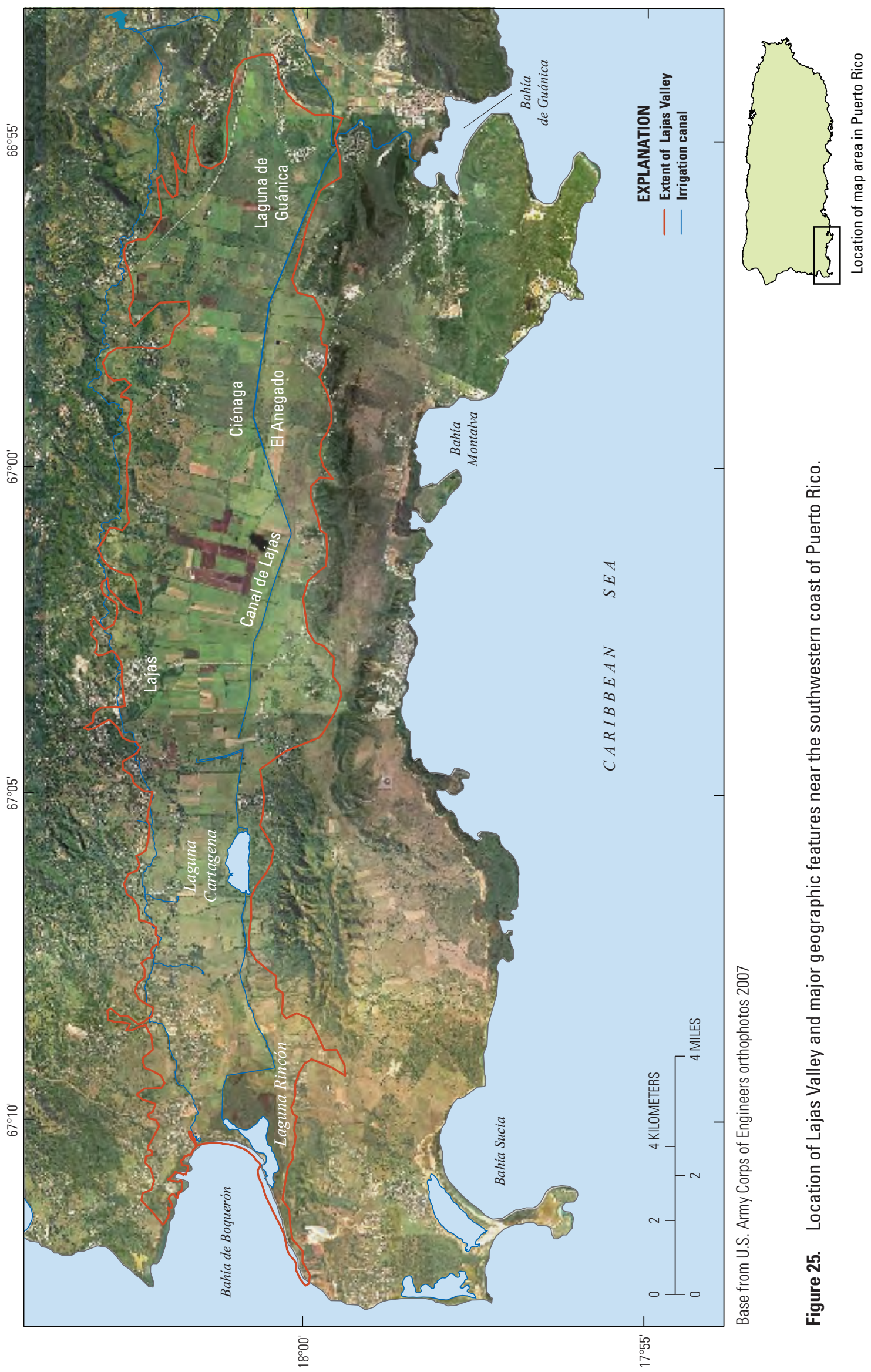




\section{Interior Province}

The Interior Province comprises all areas within the interior part of the island that have not been described previously. The Interior Province also includes the volcanic and carbonate rocks that crop out in southwestern Puerto Rico. The only principal aquifers in this province are found in the Caguas-Juncos and the Cayey valleys, which have a total area of $141 \mathrm{~km}^{2}$ (fig. 14).

The Caguas-Juncos valley covers about $130 \mathrm{~km}^{2}$ and is underlain by alluvial deposits that consist of clay, sand, and gravel. The maximum known thickness of the deposits is $37 \mathrm{~m}$; however, thicknesses generally are less than $18 \mathrm{~m}$ in most areas of the valley.

The Cayey valley covers about $11 \mathrm{~km}^{2}$ and also is underlain by alluvium that predominantly consists of clay and rock fragments. The average thickness of the alluvium is about $8 \mathrm{~m}$; the thickness of the underlying weathered rock is as much as $15 \mathrm{~m}$. In both valley areas, the principal source of recharge to the aquifers is rainfall that percolates downward through the unconsolidated deposits and eventually infiltrates through the underlying weathered or fractured rocks. The average yield of wells tapping the aquifers in these valleys is $10 \mathrm{~L} / \mathrm{s}$.

A hydrologic assessment was conducted in the CaguasJuncos valley in the early 1990s (Puig and Rodriguez, 1993). The data indicate that transmissivity in the valley ranges from 185 to $370 \mathrm{~m}^{2} / \mathrm{d}$ in parts of the valley where the unconsolidated alluvium is at least $30 \mathrm{~m}$ thick. Groundwater withdrawals were estimated to be about $11,000 \mathrm{~m}^{3} / \mathrm{d}$ in 1980 and about 12,300 m³/d in 2005 (Molina-Rivera and Gómez-Gómez, 2008).

In the Cayey valley, no hydrogeologic studies have been conducted; however, in areas of the valley where wells tap both the alluvium and the weathered rock, the estimated transmissivity is about $50 \mathrm{~m}^{2} / \mathrm{d}$, and estimated groundwater withdrawals in 1990 were less than $2,000 \mathrm{~m}^{3} / \mathrm{d}$.

\section{Vieques and Culebra Islands}

On the island of Vieques, the Esperanza and Resolución aquifers cover an area of $16 \mathrm{~km}^{2}$ and are the only principal aquifers containing freshwater (dissolved solids concentration less than $1,000 \mathrm{mg} / \mathrm{L}$ ) (fig. 14). The aquifers are formed by alluvial deposits that thicken seaward from a feathers edge in inland areas, where volcanic rocks crop out, to as much as $27 \mathrm{~m}$ of saturated thickness along the coast. The alluvium predominantly consists of fine to coarse sand and clay, which is derived from the weathering of a granodiorite intrusive. The proportion of clay and silt in the unconsolidated deposits is greater in areas near the coast. Silt, clay, and swamp deposits interfinger with and locally cap the coarse alluvial sediments throughout most of the coast (Torres-Gónzalez, 1989). Estimates of aquifer transmissivity for the two aquifers range from $185 \mathrm{~m}^{2} / \mathrm{d}$ in the vicinity of Ensenada Sombe (Sunbay) to less than $20 \mathrm{~m}^{2} / \mathrm{d}$ elsewhere on the island of Vieques.

Groundwater in the Esperanza and Resolución aquifers is unconfined, except near the coast where swamp deposits overlie the alluvium and result in semiconfined conditions. Recharge to both aquifers occurs during periods of intense rainfall. Recharge occurs as direct infiltration through the alluvial deposits or as infiltration of runoff from upland areas. Discharge occurs as seepage to wetlands or as subsurface seepage to the seabed near the shoreline. Groundwater was withdrawn primarily from the Esperanza aquifer for public water supply. Withdrawals of about $2,500 \mathrm{~m}^{3} / \mathrm{d}$ from the principal public water-supply well field near Ensenada Sombe (Sunbay) reached a peak in the mid 1970s. Withdrawals from the well field were reduced because of saltwater encroachment. In 1978, all withdrawals from the well field were discontinued when an underwater pipeline between Vieques island and Puerto Rico was completed. In 1990, the only major use of groundwater on Vieques island was for a military installation; withdrawals were estimated to be less than $100 \mathrm{~m}^{3} / \mathrm{d}$. By 2000, all military installations on the island were closed and withdrawals ceased.

Aquifers on Culebra island are formed by volcanic rocks and alluvial deposits underlying the coastal embayments (plate 2). The total estimated thickness of the unconsolidated deposits in the embayments (alluvium and weathered rock) is less than $18 \mathrm{~m}$. Most wells on the island of Culebra are shallow, dug wells that supply water to livestock. To augment the water supply of the island, several wells were drilled within an upland depression; however, the sustained yield of these wells was less than $20 \mathrm{~m}^{3} / \mathrm{d}$. An underwater pipeline connecting Culebra to the public water supply of Vieques island was constructed around 1989. 


\section{Mona Island}

Information on the groundwater resources of Mona island is sparse; only four shallow, dug wells are located in the coastal plain on the southwestern end of the island (plate 2; fig. 26). The coastal plain rises to about $5 \mathrm{~m}$ above mean sea level and consists of sand and reef deposits. No springs have been reported emerging from the cliffs even during major rainstorm events, which may indicate that the limestone and underlying calcitic dolomite have a high permeability and are capable of conveying a large percentage of the infiltrating rainfall to the water table. If an aquifer exists within the Isla de
Mona Dolomite, it may resemble a typical Ghyben-Herzberg freshwater lens given the circular shape of the island and the propensity for dissolution in dolomites (Verrjuit, 1968). The groundwater quality, however, would most likely have a dissolved solids concentration greater than $1,000 \mathrm{mg} / \mathrm{L}$, even at the apex of the freshwater lens as a result of the seawater aerosol over the island. Groundwater quality can be inferred from the analyses of water samples obtained from a pool in Cueva de los Pájaros (also known as Cueva del Caballo) and samples collected from the four dug wells and a brackishwater pond (Manglar Sardinera) at Punta Arenas (fig. 6; Puerto Rico Environmental Quality Board, 1973).

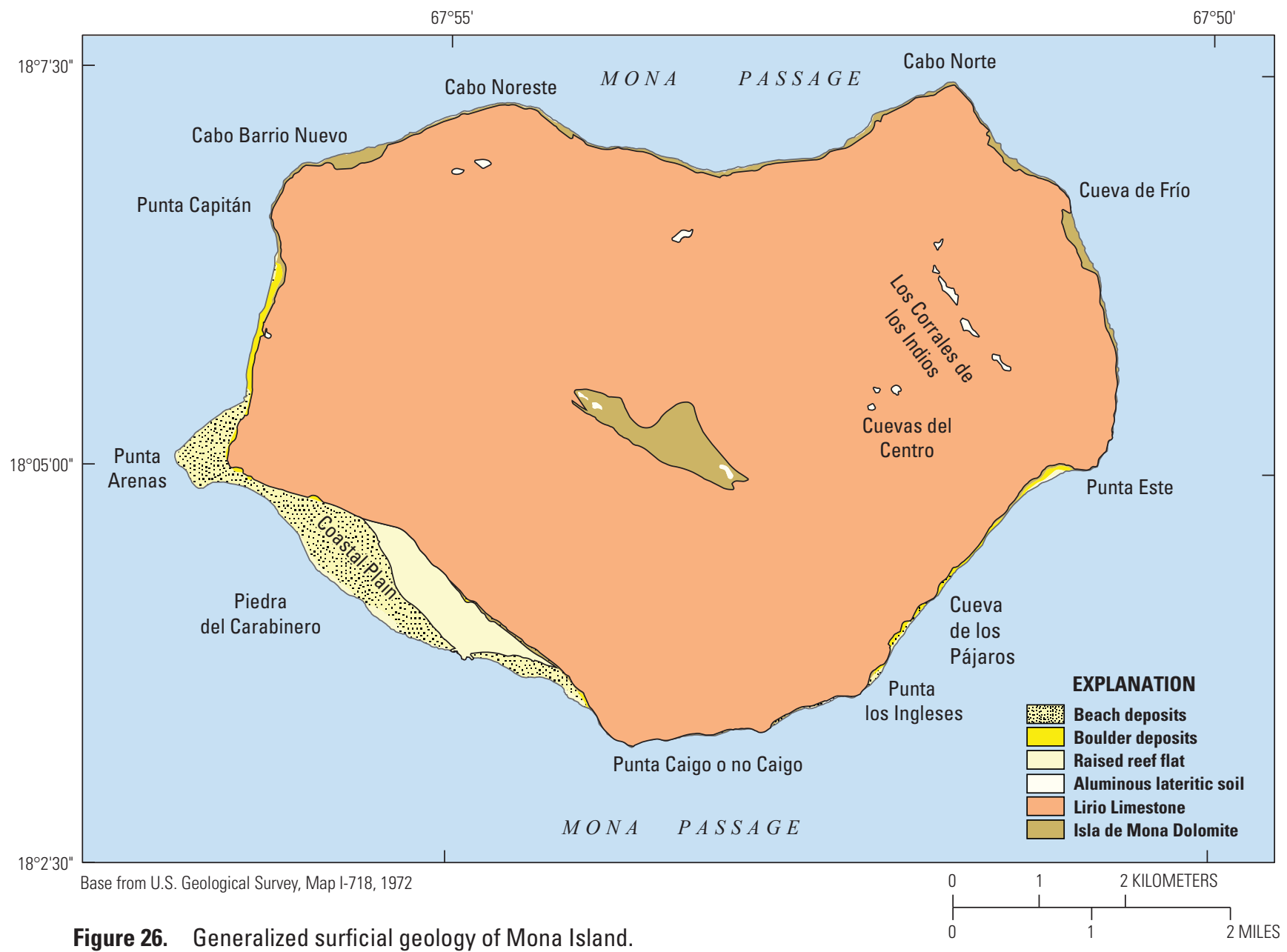




\section{Summary and Conclusions}

The availability of hydrogeologic maps for Puerto Rico and the outlying islands of Vieques, Culebra, and Mona are important to hydrogeologists, groundwater specialists, and water resource managers and planners. These maps, in combination with the report, serve as a source of information to all users by providing basic hydrogeologic and hydrologic knowledge in a concise illustrated format.

Puerto Rico and the outlying islands cover a total area of 8,927 square kilometers $\left(\mathrm{km}^{2}\right)$. Of this total area, about $3,500 \mathrm{~km}^{2}$ are underlain by hydrogeologic units that are classified as intergranular or fissured. These hydrogeologic units form the principal aquifer systems throughout Puerto Rico and the outlying islands.

In Puerto Rico, the most extensive and intensely developed aquifers are the North Coast Limestone aquifer system and the South Coastal Alluvial Plain aquifer system. Withdrawals from these two aquifer systems constitute nearly 70 percent of the total groundwater withdrawn in Puerto Rico.

The spatial extent of the North Coast Limestone aquifer system is about $2,000 \mathrm{~km}^{2}$. Within this aquifer system, groundwater development is greatest in the $800-\mathrm{km}^{2}$ area between the Río Grande de Arecibo and the Río de la Plata. This also is the area for which concern is the highest regarding the future use of groundwater as a primary source of water for domestic and industrial use. With an estimated withdrawal of 280,000 cubic meters per day $\left(\mathrm{m}^{3} / \mathrm{d}\right)$, groundwater constituted the principal source of water within this area providing 100 percent of the water for self-supplied industries and about 85 percent for public water supplies in 1985. By 2005, groundwater withdrawals decreased to $150,000 \mathrm{~m}^{3} / \mathrm{d}$.

The spatial extent of the South Coastal Alluvial Plain aquifer system is about $470 \mathrm{~km}^{2}$. The estimated consumptive groundwater withdrawal from the aquifer system was $190,000 \mathrm{~m}^{3} / \mathrm{d}$ in 1980 and $170,000 \mathrm{~m}^{3} / \mathrm{d}$ in 2005 . About 60 percent and 40 percent of the groundwater withdrawal from the South Coastal Alluvial Plain aquifer system was used for public water supply and irrigation, respectively.

In the outlying islands of Vieques, Culebra, and Mona, only Vieques is underlain by aquifers of any local importance. The Resolución and Esperanza aquifers underlie an area covering $16 \mathrm{~km}^{2}$ on the island of Vieques. Prior to 1978 when an underwater public water-supply pipeline connecting Vieques to the main island of Puerto Rico was completed, groundwater withdrawal from the two aquifers was as much as 2,500 $\mathrm{m}^{3} / \mathrm{d}$. Groundwater withdrawals in Vieques island in 2005 were estimated at less than $100 \mathrm{~m}^{3} / \mathrm{d}$.

The potential development of relatively untapped groundwater resources in Puerto Rico is limited to the Río Grande de Añasco valley and the Río Culebrinas valley in the western part of the island and to the Río Grande de Arecibo part of the North Coast Limestone aquifer system. In general, the North Coast Limestone and the South Coastal Alluvial Plain aquifer systems, which are the two principal groundwater-flow systems in Puerto Rico, show evidence of aquifer overdraft as indicated by regional increases in concentrations of dissolved solids.

Optimization of withdrawals through conjunctive use of both surface-water and groundwater sources and by instituting water conservation measures has the greatest potential to ensure the continued use of groundwater resources. In support of these efforts, programs also could be implemented to improve database information regarding groundwater withdrawals and the contribution of surface-water diversions to surface-water flow, especially within the southern coastal plain of Puerto Rico.

\section{Selected References}

Adolphson, G., Seijo, M.A., and Robison, T.M., 1977, Water resources of the Maunabo valley, Puerto Rico: U.S. Geological Survey Water-Resources Investigations Report 76-115, $44 \mathrm{p}$.

Anderson, H., 1976, Ground water in the San Juan metropolitan area, Puerto Rico: U.S.Geological Survey WaterResources Investigations Report 41-75, 34 p.

Anderson, H.R., 1977, Ground water in the Lajas Valley, Puerto Rico: U.S. Geological Survey Water-Resources Investigations Report 68-76, 45 p.

Bawiec, W.J., ed., 1998, Geology, geochemistry, geophysics, mineral occurrences, and mineral resource assessment for the commonwealth of Puerto Rico: U.S. Geological Survey Open-File Report 98-38.

Bennet, G., and Giusti, E.V., 1972, Ground water in the Tortuguero area, Puerto Rico — As related to proposed harbor construction: Commonwealth of Puerto Rico Water-Resources Bulletin 10, 25 p.

Bogart, D.B., Arnow, T., and Crooks, J.W., 1964, Water resources of Puerto Rico-A progress report: Commonwealth of Puerto Rico Water-Resources Bulletin 4, 102 p.

Briggs, R.P., 1961, Geology of the Kewanee Interamerican Oil, Co. test well number CPR4, northern Puerto RicoOil and gas possibilities of northern Puerto Rico: San Juan, Puerto Rico Mining Commission, p. 1-23.

Briggs, R.P., and Ackers, J.P., 1965, Hydrogeologic map of Puerto Rico and adjacent islands: U.S. Geological Survey Hydrologic Investigations Atlas HA-197, scale 1:240,000.

Briggs, R.P., and Seiders, V.M., 1972, Geologic map of the Isla de Mona Quadrangle, Puerto Rico: U.S. Geological Survey Miscellaneous Geologic Investigations Map I-718, 1 sheet, scale 1:20,000.

Colón, J.A., 1983, Algunos aspectos de la climatología de Puerto Rico: Acta Científica v. 1, no. 2-3, p. 55-63. 
Colón-Dieppa, Eloy, and Quiñones-Marquez, Ferdinand, 1985, A reconnaissance of the water resources of central Guanajibo valley Puerto Rico: U.S. Geological Survey Water-Resources Investigations Report 82-4050, 47 p.

Curtis, R.E., Aquino, Z., Diaz, P.L., and Vachier, R., 1987, Water records data Puerto Rico and the U.S. Virgin Islands water year 1987: U.S. Geological Survey Water-Data Report PR-87-1, 356 p.

Díaz, J.R., and Jordan, D.G., 1987, Water resources of the Río Grande de Añasco-Lower valley, Puerto Rico: U.S. Geological Survey Water-Resources Investigations Report 85-4237, 48 p.

Giusti, E.V., and Bennett, G.D., 1976, Water resources of the north-coast limestone area, Puerto Rico: U.S. Geological Survey Water-Resources Investigations Report 42-75, 42 p.

Glover, L., III, 1971, Geology of the Coamo area, Puerto Rico, and its relation to the volcanic arc-trench association: U.S. Geological Survey Professional Paper 636, 102 p.

Gómez-Gómez, Fernando, 1987, Planning report for the Caribbean Islands Regional Aquifer-System Analysis Project: U.S. Geological Survey Water-Resources Investigations Report 86-4074, 50 p., 3 p.

Gómez-Gómez, Fernando, 1991, Hydrochemistry of the south coastal plain aquifer system of Puerto Rico and its relation to surface water recharge: American Water Resources Association monograph series no. 15, 113 p.

Gómez-Gómez, Fernando, and Heisel, J., 1980, Summary appraisals of the Nation's ground-water resourcesCaribbean Region: U.S. Geological Survey Professional Paper 813-U, 32 p.

Gómez-Gómez, Fernando, and Torres-Sierra, Heriberto, 1988, Hydrology and effects of development on the water-table aquifer in the Vega Alta quadrangle, Puerto Rico: U.S. Geological Survey Water-Resources Investigations Report 87-4105, 54 p.

Graves, R.P., 1989, Water resources of the Humacao-Naguabo area, eastern Puerto Rico: U.S. Geological Survey WaterResources Investigations Report 87-4088, 69 p.

Hartley, J.R., 1989, Subsurface geology of the Tertiary carbonate rocks, northwestern Puerto Rico: New Orleans, University of New Orleans, unpublished M.S. thesis, 214 p.

Kaye, C.A., 1959, Geology of Isla Mona, Puerto Rico, and notes on age of Mona Passage: U.S. Geological Survey Professional Paper 317-C, 178 p.

Mattson, P.H., 1960, Geology of the Mayagüez area, Puerto Rico: Bulletin of the Geological Society of America, v. 71, p. 319-362.
McGuinnes, C.L., 1948, Groundwater resources of Puerto Rico: Puerto Rico Aqueducts and Sewer Service, 613 p.

Meyerhoff, H.A., 1933, Geology of Puerto Rico: Puerto Rico University Monograph Series B, Physical and Biological Sciences, no. 1, 306 p.

Molina-Rivera, Wanda, and Gómez-Gómez, Fernando, 2008, Estimated water use in Puerto Rico, 2005: U.S. Geological Survey Open-File Report 2008-1286, 37 p.

Monroe, W.H., 1976, The karst landforms of Puerto Rico: U.S. Geological Survey Professional Paper 899-D, 69 p.

Monroe, W.H., 1980, Geology of the middle Tertiary formations of Puerto Rico: U.S. Geological Survey Professional Paper 953, 93 p.

National Oceanographic and Atmospheric Administration, 1982, Climate of Puerto Rico and Virgin Islands, in Climatography of the United States No. 60, 25 p.

Neumann, Eduardo, 1913 (Reprinted 1987), Verdadera y Auténtica Historia de la Ciudad de Ponce: Instituto de Cultura Puertorriqueña, 284 p.

Picó, R., 1964, Geografia de Puerto Rico: Parte II Geografia Económica: Editorial Universitaria, Universidad de Puerto Rico, Río Piedras, 220 p.

Potential of the Central American-Caribbean Region: CircumPacific Council for Energy and Mineral Resources, Earth Science Series, Springer-Verlag, v. 16, p. 369-377. Also reprinted: Gómez-Gómez, Fernando, Quiñones-Aponte, Vicente, and Johnson, A.I., eds., Regional aquifer systems of the United States, aquifers of the Caribbean Islands: American Water Resources Association Monograph Series no. 15 , p. $25-36$.

Puerto Rico Environmental Quality Board, 1973, Las islas de Mona y Monito B Una evaluación de sus recursos naturales e históricos, v. no. 1, Junta de Calidad Ambiental, San Juan, Puerto Rico, 47 p.

Puig, J., and Rodriguez, J.M., 1993, Ground-water resources of the Caguas-Juncos valley, Puerto Rico: U.S. Geological Survey Water-Resources Investigations Report 91-4079, $52 \mathrm{p}$.

Quiñones, Ferdinand, and López, Marisol, 1984, Publications of the U.S. Geological Survey, Water Resources Division for Puerto Rico and the U.S. Virgin Islands, 1946-1984: U.S. Geological Survey Open-File Report 84-229, 32 p.

Quiñones-Marquez, Ferdinand, and Fusté, L.A., 1978, Limnology of Laguna Tortuguero, Puerto Rico: U.S. Geological Survey Water-Resources Investigations Report 77-122, 86 p. 
Ramos-Ginés, Orlando, 1999, Estimation of magnitude and frequency of floods for streams in Puerto Rico- New empirical models: U.S. Geological Survey Water-Resources Investigations Report 99-4142, $41 \mathrm{p}$.

Renken, R.A., Gómez-Gómez, Fernando, Quiñones-Aponte, Vicente, and Dacosta, Rafael, 1995, Structure and depositional patterns and their influence on the hydraulic conductivity of fan deltas in southern Puerto Rico, in Miller, R.L., Escalante, G., Reinemund, J.A., and Bergin, M.J., eds., Energy and Mineral Potential of the Central American-Caribbean Regions: Heidelberg, Springer-Verlag, p. 369-377.

Renken, R.A., Ward, W.C., Gill, I.P., Gómez-Gómez, Fernando, Rodríguez-Martínez, Jesús, and others, 2002, Geology and hydrogeology of the Caribbean Islands aquifer system of the Commonwealth of Puerto Rico and the U.S. Virgin Islands: U.S. Geological Survey Professional Paper 1419, 139 p., 5 pls.

Robison, T.M., and Anders, R.B., 1973, Electrical analog model study of the alluvial aquifer in the Yabucoa valley, Puerto Rico, Phase 2-The planning, construction and use of the model: U.S.Geological Survey Water-Resources Investigations Report 73-1, $22 \mathrm{p}$.

Santiago-Rivera, Luis, 1992, Low-flow characteristics at selected sites on streams in eastern Puerto Rico: U.S.Geological Survey Water-Resources Investigations Report 92-4063, 46 p.

Santiago-Rivera, Luis, 1996, Low-flow characteristics at selected sites on streams in southern and western Puerto Rico: U.S.Geological Survey Water-Resources Investigations Report 95-4147, 46 p.

Santiago-Rivera, Luis, 1998, Low-flow characteristics at selected sites on streams in northern and central Puerto Rico: U.S.Geological Survey Water-Resources Investigations Report 98-4200, 53 p.

Scharlach, R.A., 1990, Depositional history of OligoceneMiocene carbonate rocks, subsurface of northeastern Puerto Rico: New Orleans, University of New Orleans, unpublished M.S. thesis, $242 \mathrm{p}$.
Struckmeiser, W.F., and Margat, Jean, 1995, Hydrogeological maps - A guide and a standard legend: International Association of Hydrogeologists, v. 7, 177 p.

Torres-González, Arturo, 1984, Use of surface geophysical techniques for ground-water exploration in the CanóvanasRío Grande area, Puerto Rico: U.S. Geological Survey Water-Resources Investigations Report 83-4266, 25 p.

Torres-Gónzalez, Sigfredo, 1989, Reconnaissance of groundwater resources of Vieques island, Puerto Rico: U.S. Geological Survey Water-Resources Investigations Report 86-4100, 37 p.

U.S. Bureau of the Census, 1991, 1990 Census of Population and Housing: Puerto Rico, Bureau of Census, CPH-1-53, $199 \mathrm{p}$.

U.S. Bureau of the Census, 2012, 2010 Census Summary File 1 [Puerto Rico]/prepared by the U.S. Census Bureau, 2012 http://www.census.gov/prod/cen2010/doc/sf1.pdf.

U.S. Geological Survey, 2010, Water-resources data for the United States, Water Year 2010, at http://wdr.water.usgs.gov/.

Verrjuit, A., 1968. A note on the Ghyben-Herzberg formula: Delft, Netherlands, Technological University, Bulletin of the International Association of Scientific Hydrology, v. 13, no. 4 , p. 43-46.

Volkman, R.P., 1984, Geologic map of the Puerto Real quadrangle, southwest Puerto Rico: U.S. Geological Survey Miscellaneous Investigations Services, $1 \mathrm{pl}$.

Wilson, H.M., 1899, Water resources of Puerto Rico: U.S. Geological Survey Water-Supply Paper 32, 48 p.

Zapp, A.D., Berquist, H.R., and Thomas, C.R., 1948, Tertiary geology of the coastal plains of Puerto Rico: U.S. Geological Survey Oil and Gas Investigation Preliminary Map 85, scale $1: 60,000$. 
Manuscript approved April 1, 2014

Prepared by the USGS Science Publishing Network Raleigh Publishing Service Center

Edited by Kay P. Naugle

Illustrations by Jeffrey Corbett

Layout by Caryl J. Wipperfurth

For more information concerning this report, contact: Director, Caribbean Water Science Center

651 Federal Drive Suite 400-15

Guaynabo, PR 00965

(787) 749-4346

http://pr.water.usgs.gov/ 
ब. 